\title{
A szerkesztő előszava
}

A WHO adatai szerint a HPV világszerte bizonyítottan az összes carcinomás megbetegedés 6,1\%-át okozza, és a DNS-szekvencia alapján legalább 100 alfaj különböztethető meg, és ezek szekvenciavariánsainak elterjedése földrajzi és etnikai különbségeket mutat. Néhány, a világon szétszórtan előforduló ritka HPV-variáns jelenlétét kimutatták legalább 12000 éve izolált közösségben élő dél-amerikai indiánoknál is. Ez a megfigyelés azt a feltevést támasztja alá, hogy a papillomavírus már azelőtt megjelent, mielőtt az emberi faj kialakult és az egyes etnikai csoportok szétváltak, majd fokozatosan, hosszú fejlődési folyamaton keresztül érte el mai változatos megjelenési formáját.

Az embereket megbetegítő HPV-típusok egyik jelentős hányada a nyálkahártyákat, másik része a bőr elszarusodó laphámját támadja meg. A mucosalis HPV-típusok leggyakrabban a nói genitális traktusban mutathatók ki, szexuális úton terjednek és magas, illetve alacsony rizikócsoportba sorolhatók. A magas rizikójú vírusok közel 80\%-ban megtalálhatók analis laphámrákokban, magas százalékban fordulnak elő vulva-, vagina-, penis-, nyelőcső- és oropharingealis rákokban, végül ritkábban egyéb lokalizációkban, mint emlö- vagy húgyhólyagrák. Az alacsony rizikójú HPV-törzsek, elsősorban a HPV-6 és HPV-11 leggyakrabban papillomákban mutathatók ki.

A HPV-fertőzés, illetve az ebból adódó megbetegedések megelőzése és a kialakult jó- és rosszindulatú daganatos betegségek kezelése mind a társadalomra, mind az egészségügyre komoly terheket ró. Magyarországon a méhnyakrák jelenleg elfogadott szưrési metodikája valamelyest csökkentette a daganatos megbetegedések számát, de a halálozási arányszám nem változott. A többi lokalizációban - beleértve a bőr HPV okozta nem melanomarákjait - nincs elfogadott szürési eljárás, és megbízható országos szintű előfordulási vagy klinikai adatok sincsenek publikálva. Ezért rendkívül fontos a HPV okozta malignus és kiújuló megbetegedések társadalmi terheit Magyarországon is áttekinteni.

Az alábbi tanulmány szerzői a HPV-fertőzés különböző vonatkozásainak magyarországi szakértői. Munkájukban sokféle szempont szerint vizsgálják a lakosság HPV okozta megbetegedéseinek problémáit és a HPVfertőzés megelőzésének lehetőségeit. Részletesen elemzik a rendelkezésre álló HPV-vakcinák hatását, a gyermekkori védőoltás szervezeti, múködési feltételeit és népegészségügyi előnyeit. Európában mostanáig összesen 20 ország vette fel nemzeti immunizációs programjába a HPV elleni védőoltást. Magyarország nem tartozik ezek közé. A tanulmány szerzői remélik, hogy munkájuk megmutatja a HPV-fertőzés megelőzésének nemcsak társadalmi szintü, hanem jelentős gazdasági előnyeit is, ezzel segítve a döntéshozókat annak mérlegelésében, hogy lehetséges-e és milyen módon Magyarországon is felvenni a nemzeti oltási programba a HPV elleni védőoltást.

Prof. Dr. Kásler Miklás Pfr.D., DSc, dr.hc az Országos Onkológiai Intézet főigazgató foorvosa 
1. A humán papillomavírus okozta malignus és rekurráló megbetegedések társadalmi terhei ............................. 3

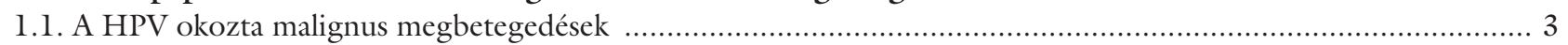

1.1.1. A HPV elleni védőoltás indikációs körébe tartozó malignus megbetegedések ........................................ 3

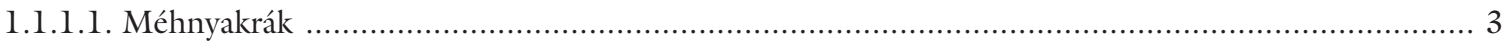

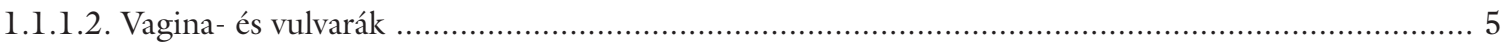

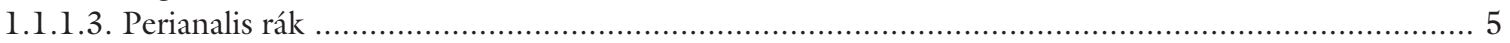

1.1.2. A HPV okozta, védőoltással potenciálisan csökkenthető,

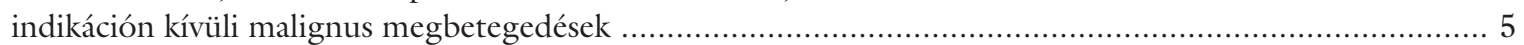

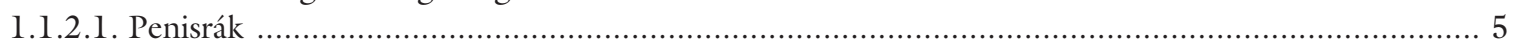

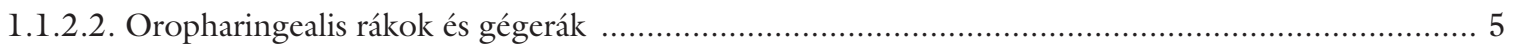

1.1.3. A HPV-vel kevésbé szoros összefüggésben álló daganatos megbetegedések ....................................6

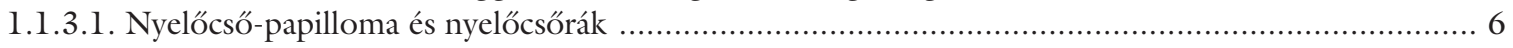

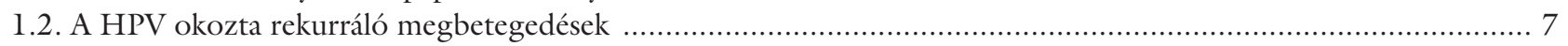

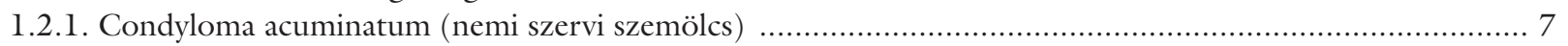

1.2.2. Rekurráló respiratorikus papillomatosis ................................................................................... 8

1.3. A HPV okozta malignus és rekurráló megbetegedések terápiás költségeinek becslése ................................... 9

1.3.1. Megfontolások a humán papillomavírus (HPV) okozta kórképek betegségterhe kapcsán ........................ 9

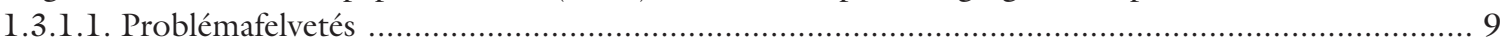

1.3.1.2. HPV-vel összefüggésbe hozható kórképek és előfordulási gyakoriságuk .................................. 9

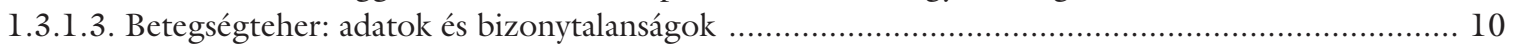

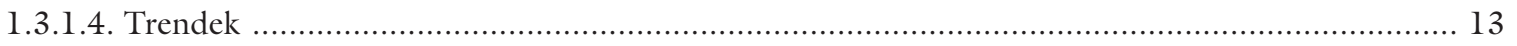

2. A HPV okozta malignus és rekurráló megbetegedések megelőzésére szolgáló vakcinák ............................. 16

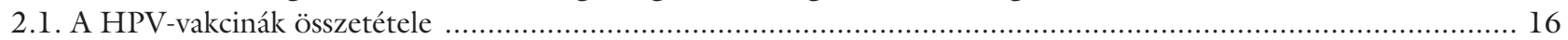

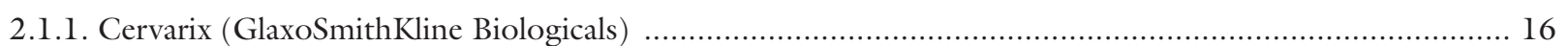

2.1.2. Silgard (GARDASIL; Merck Sharp \& Dohme) ........................................................................ 16

2.2. A HPV-vakcinák protektív hatásának mechanizmusa ..................................................................... 17

2.3. A HPV-vakcinák betegségmegelőző hatása klinikai vizsgálatokban ......................................................... 19

2.3.1. A bivalens vakcina betegségmegelőző hatása (alkalmazási elő́rás) ................................................. 19

2.3.2. A kvadrivalens vakcina betegségmegelőző hatása (alkalmazási előírás) ............................................ 20

2.3.3. A kvadrivalens és a bivalens vakcina hatályos alkalmazási elő́rásának összehasonlítása .............................222

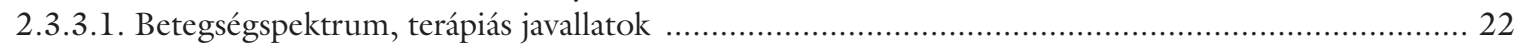

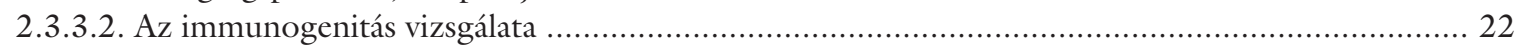

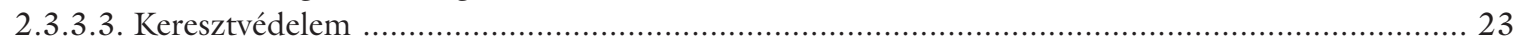

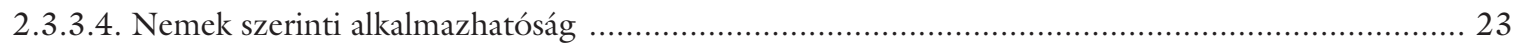

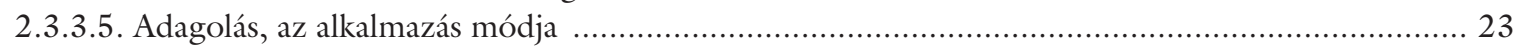

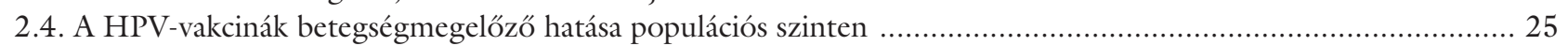

2.4.1. A vakcináció hatása a méhnyak rákmegelőző állapotainak incidenciájára ....................................... 25

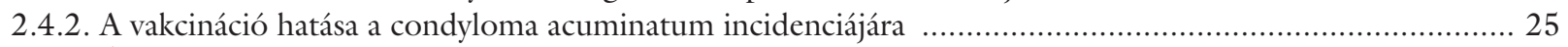

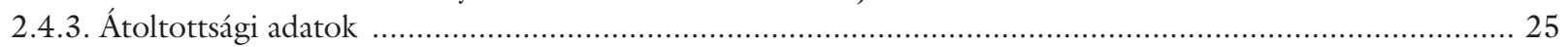

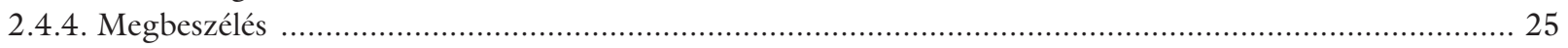

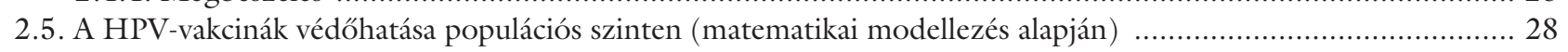

2.5.1. A HPV-vakcinák társadalmi hatásának modellezése (a brit Health Protection Agency [HPA] elemzése) ... 28

2.6. A HPV-vakcinák biztonságossági profilja .................................................................................... 31

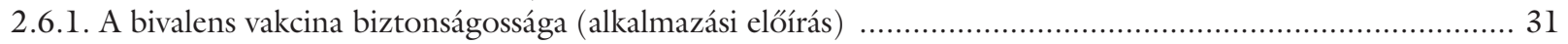

2.6.2. A kvadrivalens vakcina biztonságossága (alkalmazási előírás) …................................................. 31

3. Javaslat a HPV okozta megbetegedések megelőzésének népegészségügyi programjára ................................ 33

3.1. A jelen: szekunder prevenció méhnyakrákszúréssel .......................................................................... 33

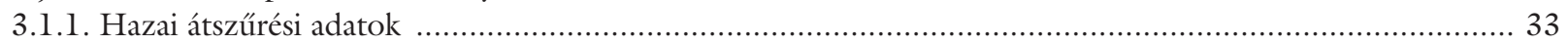

3.1.2. Az elkerült betegségek és halálozások becsült száma .......................................................... 33

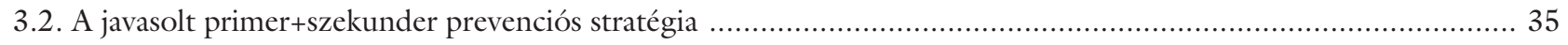

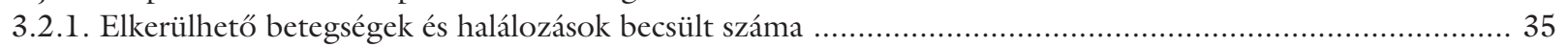

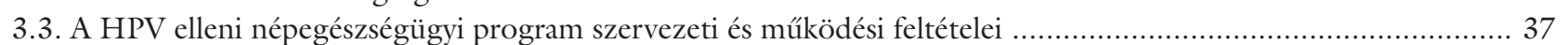

3.3.1. A gyermekkori/serdülőkori védőoltási kampány implementációja .................................................. 37

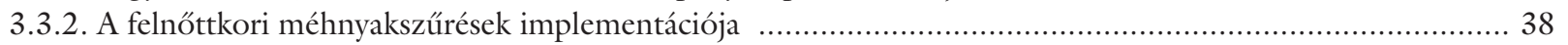




\section{1. \\ A humán papillomavírus okozta malignus és rekurráló megbetegedések társadalmi terhei}

A humán papillomavírus (HPV) egy kisméretú, burok nélküli, kettős szálú DNS-vírus, amelynek legalább 100 típusát különböztetjük meg. Megközelítőleg 30-40 típusról ismert, hogy megfertózheti az anogenitalis régióban lévő bőr epitheliumrétegét vagy a nyálkahártyát [1]. A HPV egy nagyon gyakori és gyorsan, elsősorban szexuális úton terjedó vírus. Több mint $50 \%$ annak az esélye, hogy valaki az élete folyamán HPV-fertőzésen esik át [2]. Az anogenitalis fertózések 90\%-a spontán eliminálódik és nem okoz betegséget, de ha a fertőzés perzisztál (definíció szerint több mint egy évig kimutatható a vírus), akkor fennáll az intraepithelialis dysplasia kialakulásának lehetősége. A vírus több évig, sôt évtizedig perzisztálhat tünetmentesen, tehát a fertőzés és a daganat kialakulása között hosszú idő telhet el. A vakcinációtól eltérően, a természetes HPV-fertőzés legyőzése után nem alakul ki védettség, az újrafertőződés nagyon gyakori [3].

A HPV-típusokat genetikai hasonlóságuk és rákot okozó hajlamuk alapján magas és alacsony rizikócsoportba soroljuk. Amennyiben nagy rizikójú HPV-típus okozta a fertőzést, fennáll a malignus elfajulás veszélye. A nagy rizikójú HPV-típusok a felelősek a méhnyakrákok 99-100\%-áért, a vulvarákok 60\%-áért, a vaginarákok $70 \%$-árt, az analis rákok $85 \%$-áért, és a fej-nyaki rákok közül például a tonsillarákok $80 \%$-árt.

A nagy rizikójú HPV-típusok közül a HPV-16 és -18 okozza a méhnyakrákok $70 \%$-át, a vulvarákok $80 \%$-át, az analis rákok 92\%-át, a szájüregi daganatok 95\%-át [3].

A kis rizikójú HPV-típusok felelősek néhány jóindulatú, de nehezen kezelhetó és komoly pszichés terhet jelentő betegség kialakulásáért. A nőket és férfiakat egyaránt érintő, az anogenitalis régióban előforduló szemölcsök (condyloma acuminatum) $90-100 \%$-a a HPV-6 és -11 fertőzésnek tulajdonítható. Irodalmi adatok alapján a condyloma előfordulásának esélye az élet folyamán $10 \%$ körül van. Ugyancsak ezek a típusok a felelősek a rekurráló respiratorikus papillomatosis kialakulásáért, amelyek jelentős része már ötéves kor előtt manifesztálódik. Ezekben az esetekben a fertőzés már születéskor megtörténik, és a fertőzés forrása a terhesség alatt akut condylomás elváltozással rendelkező anya $[4,5]$.

\subsection{A HPV okozta malignus megbetegedések}

\subsubsection{A HPV elleni védöoltás indikációs körébe tartozó malignus megbetegedések}

\subsubsection{Méhnyakrák}

A Magyar Nemzeti Rákregiszter adatai szerint Magyarországon a méhnyakrákos megbetegedések száma a 2001. évi 1356-os előfordulási gyakoriságról a bevezetett szúrốprogramok hatására 2010-re 932-re csökkent, de a nôk között még mindig ez a nyolcadik leggyakoribb daganatos megbetegedés. Méhnyakrákban csekély ingadozással évente mintegy 420-an halnak meg. Ez az arány 10 év alatt sem változott, és ezzel a nók között a kilencedik leggyakoribb daganatos halálok. Az ötéves túlélési arány 55\% körüli, ami 10-20\%-kal alacsonyabb, mint a hasonló kanadai, norvég, finn vagy olasz túlélési arány [6]. Négyéves intervallumban, 2002 és 2005 között vizsgálva a Rákregiszter adatait, az in situ cervixcarcinoma előfordulásának gyakorisági maximuma a 30-34 éves kor közé esik, míg az invazív méhnyakrák leggyakoribb előfordulása 8-10 évvel később figyelhető meg. Elegendő idő áll tehát rendelkezésre, hogy a méhnyakrákot megelőzzük, de ez mostanáig mégsem következett be, mert a szúrővizsgálatok a női lakosság nem minden részét érik el.

A HPV-típusokat genetikai hasonlóságuk és rákot okozó hajlamuk alapján magas és alacsony rizikócsoportba soroljuk. Korábbi becsléseink szerint Magyarországon a felnőtt nói lakosság körülbelül 25\%-a HPV-vel fertőzött [7], azonban a daganatos transzformáció megindulása az irodalomból ismert rizikófaktorok jelenléte mellett is nagymértékben a HPV-fertőzés jellegétôl függ [8]. A méhnyakrák az úgynevezett transzformációs zónában alakul ki. A vírus a squamocolumnaris junctióban, a laphám-metaplasia vagy a hámsérülés területében hatol be, és más vírusfertőzésektól teljesen eltérően elóbb a bazális membránhoz kötődik, mielőtt a többrétegú laphám bazális sejtjeinek felszínéhez kötődik, majd belép a sejtekbe [9]. Az nem ismert, hogy a HPV mennyi ideig marad a bazális membránhoz kapcsolódva. Ha a páciens előzetesen HPV elleni védőoltást 
kapott, akkor ebben a stádiumban a laphám alatti kapillárisokból vagy a hámsérülés által kiváltott exudátumból az anti-HPV-IgG könnyen eléri a bazális membránon lévő víruspartikulumokat és közömbösítheti azokat. Abban az esetben, ha a HPV már belépett a hámsejtbe, a védőoltás hatástalan. Ha a HPV a sejtekben episomalis formában van jelen, LSIL (low grade squamosus laesio) alakul ki, ami az esetek felében reverzíbilis. Ha a gyürü alakú HPV-DNS felszakad és a vírus integrálódik a sejt genomjába, HSIL (high grade squamosus laesio, CIN2-CIN3) alakul ki. Az LSIL progresszióját HSIL-be az alábbi tényezők segítik elő: a) perzisztáló HPV-fertőzés, ami akkor áll fenn, ha ugyanaz a HPVtípus egy év múlva is kimutatható; b) magas rizikójú HPV-típusok; c) többes vírusfertőzés és ezzel együtt magas a víruskópiaszám (high viral load), ami egy sejtbe akár több kópiavírus-DNS beépüléséhez is vezethet.

A HPV-típusok előfordulási gyakoriságát Magyarországon az 1 . ábra mutatja.

Citológiai vizsgálatra és egyidejű HPV-tesztre beküldött 1302 cervix citológiai mintában a HPV-fertőzés megoszlása a következő volt: HPV-negatív minta 41,2\%-ban, mintánként egy vírus $35,1 \%$-ban, végül mintánként két vagy több HPV-típus 23,7\%-ban fordult elő. A HPV-típusok 60\%-a magas rizikójú, 40\%-a alacsony rizikójú csoportba tartozott. Ha csak a többes vírusfertőzést vesszük, az 54\%-ban HR és 46\%-ban LR-HPV típusokból tevődött össze, és a kimutatott vírusfajták száma citológiai mintánként 2 és 9 között változott. Többes vírusfertőzésnél a kiemelt HPV-típusok gyakorisági sorrendje az ábrán bemutatott előfordulási gyakoriságtól többé-kevésbé eltér az alábbiak szerint. HR- csoport: HPV 16, 51, 52, 31, 39, 58, 18. LR-csoport: HPV 53, 61, CP6108, 62, 66, 42, 84, 6, 73, 56, 81, 83, 11. Ha egy citológiai mintában csak egyféle HPV fordult elo,, akkor HSIL-ben egyebek mellett a HPV-16 előfordulási gyakorisága 12,7\%, a HPV-18-é 11,1\%; LR-HPV HSIL-ben nem fordult elő. Többes HPVfertőzés esetén ez az előfordulási gyakoriság HSIL-ben jelentősen megváltozik, HPV-16 22,5\%-ban, HPV-18 5,3\%-ban és HPV-6 10\%-ban mutatható ki. Mindez azt jelenti, hogy a többes vírusfertőzés önmagában is magasabb HPV-kópiaszámmal jár. Kiemelendő, hogy többes vírusfertőzésnél az alacsony rizikójú HPV-típusok (például HPV-6 és HPV-11) is megjelenhetnek HSIL-ben, vagyis úgy viselkednek, mint a magas rizikójú HPV-féleségek [10]. A transzformáció folyamata többes vírusfertőzésnél lehet gyorsabb, mint egyedüli vírusfertőzésnél, a kormegoszlás alapján általunk becsült LSIL $\rightarrow$ HSIL átmenet ideje három év. Összefoglalva, a többes vírusfertőzés Magyarországon meglepően gyakori, és lényegében a vírusösszetételtől függetlenül magas rákkockázatot jelent.

Ha a méhnyak rákmegelőző állapota kialakult és azt a kolposzkópos és citológiai vizsgálat is megerősíti, az elváltozást rendszerint conisatióval eltávolítják. Ezen beavatkozás után, megfigyeléseink szerint, a betegek fele továbbra is HPV-pozitív marad, annak ellenére is, hogy a dysplasticus elváltozás teljes egészében eltávolításra került. Ez után rendszeres citológiai és időnkénti HPVkontroll következik, amíg a páciens vírusmentessé válik, vagy egy újabb dysplasiás folyamat megjelenik. Korábbi szövettani minták és hosszú idejü betegkövetési adatok felhasználásával arra voltunk kíváncsiak, hogy ezekben az

1360 HPV (35-féle vírus) előfordulási gyakorisága cervix citológiai mintákban
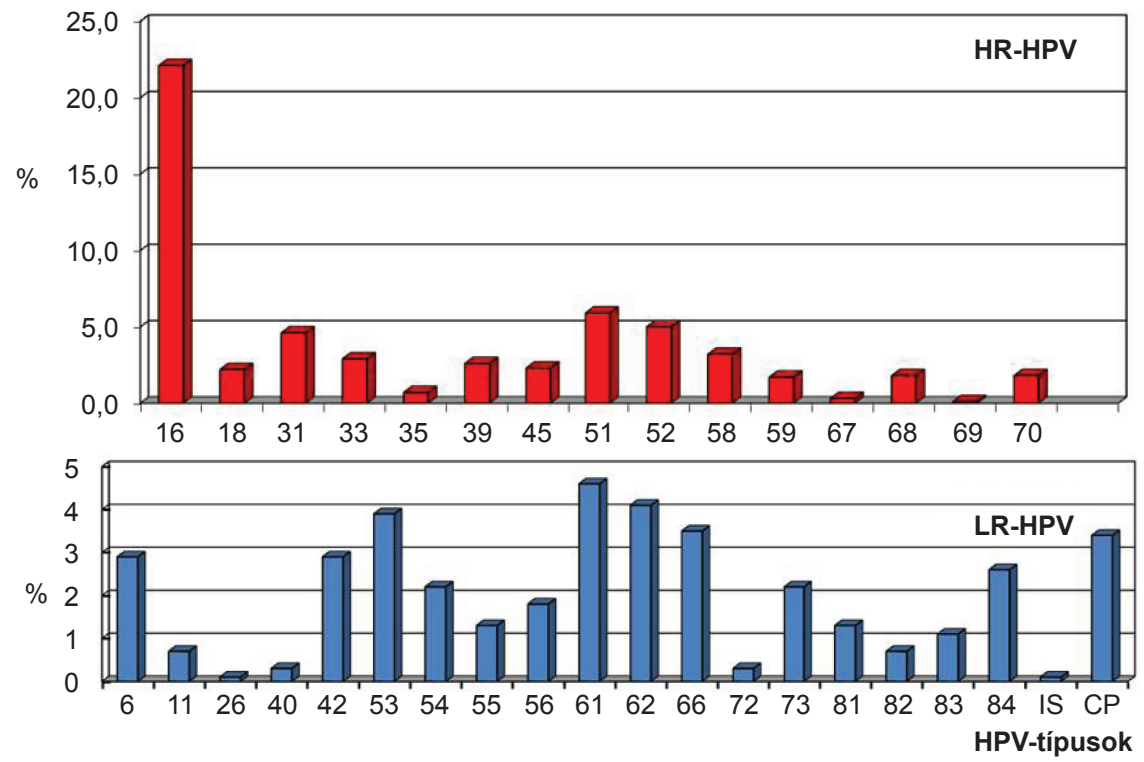

IS = IS39 HPV; CP = CP6108 HPV

1. ábra $\quad$ A leggyakrabban elöforduló HPV-típusok gyakorisági sorrendje a következó: HR-csoport: HPV 16, 51, 52, 31, 58, 33, 39, 18. LR-csoport: HPV 61, 62, 53, 66, CP6108, 6, 42, 84, 54, 73

$\mathrm{HR}=$ high risk $\mathrm{LR}=$ low risk 


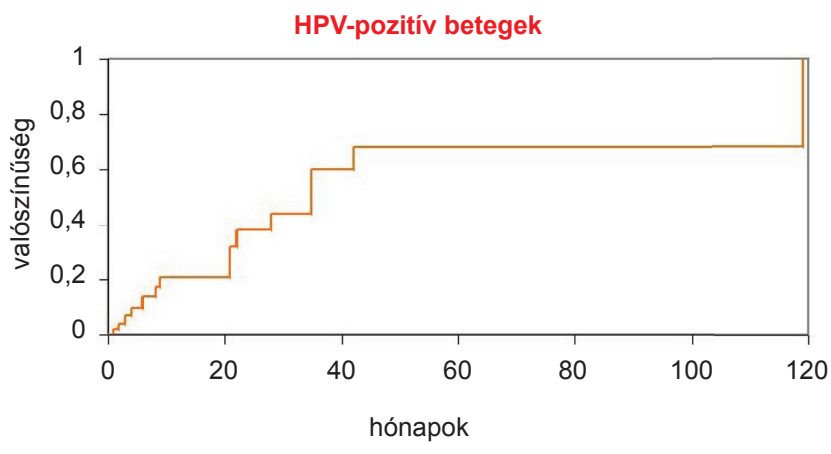

2. ábra

A méhnyak atípusos hámelváltozásai kialakulásának valószi nüsége a conisatio után eltelt idö függvényében védöoltást nem kapott HPV-pozitín betegekben. Az újabb LSIL vagy HSIL ki alakulásának valószinüsége a conisatiót követō négy évben a legnagyobb, de megfigyeltünk 10 év után is megjeleno" rákmegelözo állapotot

esetekben az újabb atípusos hámelváltozás kialakulásának milyen az időbeli valószínúsége, ha a betegek HPVellenes védőoltást még nem kaptak (2. ábra).

\subsubsection{Vagina- és vulvarák}

Magyarországon a Nemzeti Rákregiszter adatai szerint a hüvelyrák előfordulási gyakorisága a 2001-2010 időintervallumban 75 és 107 megbetegedés között ingadozott, a halálozás pedig évi 18 és 38 eset között változott. Szeméremtestrákos megbetegedés a fenti időintervallumban 171 és 221 megbetegedés közötti gyakorisági megoszlást mutatott. Ugyanebben az időben e daganat következtében meghaltak száma stabilan évi 80 és 100 között volt.

A vagina- és vulvarákok fejlődésmenetéről és a bennük előforduló HPV-típusok gyakorisági megoszlásáról megbízható magyarországi adatok nem állnak rendelkezésre. Feltehető, hogy a HPV-fertózés hasonló módon alakul ki, mint méhnyakrákban. Csekély számú saját megfigyelésünk szerint az említett elváltozásokban is a HPV-16 fordul elő leggyakrabban, és ez megegyezik az újabb nemzetközi adatokkal $[11,12]$.

\subsubsection{Perianalis rák}

A Magyar Nemzeti Rákregiszterben megtalálható, a végbélnyílás laphámrákjára vonatkozó gyakorisági adatok 2003-2010 között az alábbi megoszlást mutatják. Férfiaknál a megbetegedések száma 75 és 110 között, nőknél 68 és 128 között változott. A halálozási arány a 20012009 közötti időszakban férfiaknál 8 és 39, nőknél 8 és 42 személy között változott.

Ebben a régióban a HPV-fertőzés fejlődésmenetéről és a fertőzést elősegítő kockázati tényezőkről a HIVfertőzést kivéve nem rendelkezünk megbízható magyar adatokkal. Nemzetközi adatok szerint a perianalis laphámrákokban előforduló HPV-típusok gyakorisági megoszlása nem különbözik a genitalis régióban megfigyelt gyakorisági adatoktól [13].

\subsubsection{A HPV okozta, védōoltással potenciálisan csökkenthetó", indikáción kivüli malignus megbetegedések}

\subsubsection{Penisrák}

Magyarországon 2001-2010 között a penisrák előfordulási gyakorisága évi 56 és 85 megbetegedés között, halálozási aránya évi 15 és 27 eset között változott.

A férfiak genitalis HPV-fertőzöttségéről magyar adatok nem állnak rendelkezésre, becslések közel azonos gyakoriságúnak tartják, mint a nők genitalis fertőzöttsége. Saját, 50 betegen végzett megfigyeléseink szerint a penisrák gyakorisági maximuma 30 és 40 éves életkor közé esik, ami csaknem megegyezik a méhnyak in situ és invazív rákjának előfordulási gyakorisági maximumával. Az összes penisrák 54\%-ában mutattunk ki HPV-fertőzést. A vizsgálati minták többször is rossz minőségú paraffinba ágyazott szövetek voltak, ezért feltételezzük, hogy a HPV-fertőzés valós aránya a fentieknél jóval magasabb. Az összes HPV-féleség közül magasan leggyakrabban, 43\%-ban a HPV-16 fordult elő. Érdekes megjegyezni, hogy a férfi és nő partnerek között 42\%-ban legalább egy azonos vírus előfordult.

\subsubsection{Oropharingealis rákok és gégerák}

A Magyar Nemzeti Rákregiszter adatai szerint 2010-ben a címben megadott régiókban a carcinomák alábbi gyakorisági eloszlását regisztráltuk. Szájüreg (ajak kivételével): férfi 957, nő 309; garat: férfi 1500, nő 378; gége: férfi 1127, nő 206 megbetegedés. Ezek az értékek 2001 óta egyik régióban sem változtak számottevően. Az öszszesített halálozási adat 2009-ben férfiaknál 1165, nőknél 228 személy volt.

Epidemiológiai adatok bizonyítják, hogy szoros öszszefüggés van a fent említett régiók laphámrákjainak bizonyos típusai és a HPV-infekció között [14, 15]. Saját, összesen 213 betegünkben a HPV előfordulási gyakorisága a következő megoszlást mutatja: férfiak szájüreg-, garat- és tonsillarákjában $42 \%$, a nőkében $55 \%$; a férfiak gégerákjában 39,8\%, a nókében 18,2\%. A nők oropharingealis daganataiban észlelt magasabb HPV elöfordulási arány szexuális szokásokkal függhet össze.

A fent említett összes régióban együtt előforduló fejnyaki carcinomák közül a típusos elszarusodó laphámrákok 69\%-ban, a basaloid és verrucosus carcinomák 31\%-ban alakultak ki. A kétféle tumorcsoportban a HPV előfordulási gyakoriság nagyon különbözik, ami a daganatkialakulás eltérő etiológiájára enged következtetni. A típusos elszarusodó laphámrákok rendszerint dohányzással és alkoholfogyasztással függenek össze, és közöttük mindössze 23\%-ban találtunk HPV-pozitív tumort. Ebben a csoportban a HPV-fertőzés elősegíthette, de a daganatos transzformációnak valószínúleg nem volt az elsődleges kiváltó oka. Ezzel szemben a basaloid és verrucosus carinomák között a HPV-pozitív tumorok aránya 85\%, ami a HPV elsődleges transzformáló szerepére utal. 
Az összes HPV-pozitív oropharingealis rákban a HPV16 előfordulási gyakorisága 15,7\%. Meglepő lelet volt, hogy ebben a régióban 5,9\%-ban HPV-6- és HPV-11pozitív tumorok is előfordultak. Az összes HPV-pozitív gégerákban a HPV-16-pozitív tumorok aránya 16,7\%, itt HPV-6-, -11-pozitív carcinomákat nem találtunk.

\subsubsection{A HPV-vel kevésbé szoros összefüggésben álló daganatos megbetegedések}

\subsubsection{Nyelőcső-papilloma és nyelőcsőrák}

Magyarországon a 2001-től 2010-ig terjedő időintervallumban férfiaknál évi 622-792, nőknél évi 156-206 között változott a nyelőcsőlaphámrák előfordulási aránya. Irodalmi adatok utalnak rá, hogy a nyelőcsőrák is bizonyos mértékig összefügg a HPV-fertőzéssel [16, 17].

Korábban 72 nyelőcsőlaphámrák szövettani mintája közül 27 (37\%) volt HPV-pozitív tumor [18, 19]. A HPV-pozitív tumorok között 30\%-ban HPV-16 fordult elő. Vizsgáltuk továbbá 155 beteg 172 nyelőcsőpapillomájának lokalizációját és a bennük előforduló HPV-típusokat [20]. Azt találtuk, hogy a papillomák lokalizációja megegyezik a laphámrákok lokalizációjával a nyelőcsőben. Összesen 93 papillomában (54\%) tudtunk HPV-t kimutatni, amelyek között a 6-os és 11-es típus 50\%-ban, a 16-os típus 22\%-ban fordult elő. Itt érdemes megjegyezni, hogy 23 beteg Barrett-oesophagusból származó szövettani mintája közül nyolc HPVpozitív volt. Az itt előforduló vírustípusok a következők voltak: HPV-16: öt eset; HPV-42, -58, -73: egy-egy eset. Hasonlóan, Acevedo-Nuño és munkatársai összesen 68 , nyelőcsőből származó szövettani mintát vizsgáltak [21]. 17 eset volt nyelöcső-carcinoma, 28 származott Barrett-oesophagusból és 23 eset oesophagitisból. Az oesophagitisek 26\%-a, a Barrett-oesophagusok 96\%-a és a nyelőcsőrákok $88 \%$-a mutatott HPV-pozitivitást. Negyvenegy mintában (60\%) HPV-6 vagy HPV-11 fordult elő. A közölt és saját megfigyelésünk arra utal, hogy a gyulladt nyelőcső-nyálkahártya, illetve a Barrettoesophagus könnyen fertőződik HPV-vel az itt levő squamocolumnaris junctión keresztül. A HPV-fertőzés tehát jelentősen hozzájárul mind a Barrett-carcinoma, mind az egyéb lokalizációjú nyelőcsőrák kialakulásához.

\section{Felhasznált irodalom}

[1] Cogliano, V., et al.: Carcinogenicity of human papillomaviruses. Lancet Oncol., 2005, 6, 204.

[2] Sexually Transmitted Diseases (STDs). Center for Disease Control and Prevention. http://www.cdc.gov/std/hpv/stdfact-hpv.htm

[3] Grulich, A. E., et al.: Cancers attributable to human papillomavirus infection. Sexual Health, 2010, 7, 244-252.

[4] Lacey, C. J., Lowndes, C. M., Shah, K. V.: Chapter 4: burden and management of non-cancerous HPV-related conditions: HPV6/11 disease. Vaccine, 2006, 24 (Suppl. 3), S3/35-S3/41.
[5] Silverberg, M. J., Thorsen, P., Lindeberg, H., et al.: Condyloma in pregnancy is strongly predictive of juvenile-onset recurrent respiratory papillomatosis. Obstet. Gynecol., 2003, 101, 645-652.

[6] Tusnády, G., Gaudi, I., Rejtó, L., et al.: A magyar daganatos betegek túlélési esélye a Nemzeti Rákregiszter adatai alapján. Magyar Onkol., 2008, 52, 339-349.

[7] Veleczki, Zs., Petrás, S., Szentirmay, Z.: Cytological features of the genital human papillomavirus infection in 10000 cervical cytological smears. Presented in the 26th European Congress of Cytology, 26-29 September 1999, Budapest, Hungary.

[8] Wiley, D. J., Masongsong, E. V., Lu, S., et al.: Behavioral and sociodemographic risk factors for serological and DNA evidence of HPV6, 11, 16, 18 infections. Cancer Epidemiol., 2012 Jan 23.

[9] Kines, R. C., Thompson, C. D., Lowy, D. R., et al.: The initial steps leading to papillomavirus infection occur on the basement membrane prior to cell surface binding. Proc. Natl. Acad. Sci. USA, 2009, 106, 20458-20463. Epub 2009 Nov 17

[10] Szentirmay, Z., Veleczki, Zs.: A HPV-típusok magyarországi megoszlásának szerepe a méhnyakelváltozások kialakulásában. 70. Patológus Kongresszus, Siófok, 2011. szeptember 29október 1.

[11] Garland, S. M., Insinga, R. P., Sings, H. L., et al.: Human papillomavirus infections and vulvar disease development. Cancer Epidemiol. Biomarkers Prev., 2009, 18, 1777-1784.

[12] Fuste, V., del Pino, M., Perez, A., et al.: Primary squamous cell carcinoma of the vagina: human papillomavirus detection, pl6(INK4A) overexpression and clinicopathological correlations. Histopathology, 2010, 57, 907-916.

[13] Echenique, I., Phillips, B. R.: Anal warts and anal intradermal neoplasia. Clin. Colon Rectal Surg., 2011, 24, 31-38.

[14] Gillison, M. L., Koch, M. W., Capone, R. B., et al.: Evidence for a causal association between human papillomavirus and a subset of head and neck cancers. J. Natl. Cancer Inst., 2000, 92, 709-720.

[15] Szentirmay, Z., Pólus, K., Tamás, L., et al.: Human papillomavirus in head and neck cancer: clinicopathological correlations. Cancer Metast. Rev., 2005, 24, 19-34.

[16] Qi, Z., Jiang, Q., Yang, J., et al.: Human papillomavirus (HPV) infection and the risk of esophageal squamous cell carcinoma. Dis. Esophagus, 2012 Mar 9. doi: 10.1111/j.14422050.2012.01334.x.

[17] Guo, F., Liu, Y., Wang, X., et al.: Human papillomavirus infection and esophageal squamous cell carcinoma: a case control study. Cancer Epidemiol. Biomarkers Prev., 2012, Feb. 15

[18] Szentirmay, Z., Szántó, I., Melegh, Zs., et al.: Identification of human papillomaviruses (HPVs) in oral, pharyngeal, and esophageal papillomas and carcinomas. XXIII International Congress of the International Academy of Pathology and $14^{\text {th }}$ World Congress of Academic and Environmental Pathology. October 15-20, 2000, Nagoya. Abstr.: Pathol. Internat., 50: Suppl., 2000, FP-26-9

[19] Szentirmay, Z., Szántó, I., Bálint, I., et al.: Causal association between human papilloma virus infection and head and neck and esophageal squamous cell carcinoma. Magy. Onkol., 2002, 46 (1), 35-41. Epub 2003 Feb 3. Hungarian.

[20] Szántó, I., Szentirmay, Z., Banai, J., et al.: A nyelőcső laphámsejtes papillomája. Klinikai és patológiai tapasztalataink 155 beteg 172 papillomája kapcsán. Orv. Hetil., 2005, 146, 547552.

[21] Acevedo-Nuño, E., González-Ojeda, A., Vázquez-Camacho, G., et al.: Human papillomavirus DNA and protein in tissue samples of oesophageal cancer, Barrett's oesophagus and oesophagitis. Anticancer Res., 2004, 24 (2C), 1319-1323. 


\subsection{A HPV okozta rekurráló megbetegedések}

\subsubsection{Condyloma acuminatum (nemi szervi szemölcs)}

A condyloma acuminatum egy nagyon gyakori és igen fertőző betegség, amelyet 90-100\%-ban a HPV 6-os, 1l-es típusai okoznak. Pár évvel ezelőtt még úgy gondolták, hogy a condyloma fooleg az alsóbb társadalmi rétegeket érinti, azonban mára beigazolódott, hogy a HPV-fertőzött férfiakban és nőkben társadalmi rétegtől függetlenül manifesztálódhat.

Bár az anogenitalis condylomatosis nem egy életet veszélyeztető betegség, a condylomás anamnézissel rendelkező nóknél gyakran tapasztaltak fokozott rizikót a dysplasiás méhnyakelváltozások tekintetében is, amely feltehetően az egyéb, nagy rizikójú HPV-típusokkal történt együttes fertőződés eredménye. A condyloma egy jelentős, sőt nagy valószínúséggel egyre növekvő problémát jelent férfiak és nők esetében is. Gyakori elöfordulása, a beteg életminőségére gyakorolt negatív hatásai és az ellátásához kapcsolódó magas kezelési költségek miatt komoly terhet jelenthet az egyénre és a társadalomra egyaránt $[1,2,3,4,5]$.

A condyloma előfordulási gyakoriságára vonatkozóan rendelkezésünkre áll ugyan néhány felmérés eredménye, azonban a betegség természetéből adódóan ezenfelül további becslésekre is kell hagyatkoznunk. Irodalmi adatok alapján $10 \%$ annak az esélye, hogy élete során valaki condylomában fog szenvedni. A condyloma prevalenciája 4-10\% közé tehető, az évente diagnosztizált új condylomás esetek a felnőtt, szexuálisan aktív férfi és női lakosság 1\%-át érintik $[6,7]$.

A legújabb prevalenciára vonatkozó adat egy keresztmetszeti kérdőíves felmérésből származik, amelyben közel 23000 random módon kiválasztott, 18-45 éves dán férfit kérdeztek meg arról, hogy volt-e már valaha klinikailag diagnosztizált condylomájuk. A megkérdezett férfiak 8\%-a válaszolt igennel. Ez nem tartalmazza a nem diagnosztizált, illetve a be nem vallott eseteket, tehát a valós elófordulás ennél nagyobbra becsülhető [8].

Korábban Dánia, Izland, Norvégia és Svédország területén, közel 70000 nő megkérdezésével végzett kérdóíves felmérésben a megkérdezett 18-45 éves nők közel 11\%-a válaszolta, hogy már volt klinikailag diagnosztizált condylomája [9].

Mivel ezek a vizsgálatok random módon kiválasztott, reprezentatív számú, az átlagpopulációt jellemző férfiak/nők megkérdezésével történtek, ezekre az adatokra hagyatkozva azt becsülhetjük, hogy jelenleg ma Magyarországon 100000 condylomában szenvedő beteg lehet.

A condyloma acuminatum leggyakrabban a szexuálisan legaktívabb életperiódusban jelentkezik. Gyakorisága nőkben 15-24 éves, férfiakban 20-29 éves kor közt hirtelen megugrik, és mindkét nemben 20-29 éves kor között éri el maximumát. A nőkben ezután az előfordulás lényegesen csökken, de férfiakban egészen 40 éves korig magas marad [10].

A HIV-fertőzöttekben gyakoribbak a nemi szervi szemölcsök, esetükben többször észlelnek óriás condylomákat (Buschke-Löwenstein-daganatokat) is.

A klinikailag diagnosztizált condylomás esetek alapján a kórkép további rizikófaktorai közé tartozik a dohányzás, az addigi több szexuális partner, a jelenlegi partner előző partnereinek a száma, illetve az anamnézisben szereplő egyéb, szexuális úton terjedő betegség.

A HPV-fertőződés az esetek túlnyomó többségében szexuális aktus következménye, amely nemcsak genitogenitalis, hanem manuális-genitalis, orális-genitalis is lehet [10]. Feltételezhetően fertőzött eszközök, használati tárgyak is közvetíthetik, ha hámsérülés áll fenn.

$\mathrm{Az}$ is bizonyságot nyert, hogy a HPV-vírus anyáról gyermekére terjedhet a fertőzött szülőcsatornán való áthaladás közben.

A HPV 6-os vagy 1l-es típusával fertőzött nők mintegy 50\%-ában 12 hónapon belül, 64\%-ában 36 hónapon belül kialakul a condyloma acuminatum [11].

A condyloma acuminatum klinikai tünetei sokszínűek lehetnek: típusos esetben a nemi szervek területén, a gáton, a végbél körül, a lágyékban, a herezacskón, illetve a szeméremdombon egyszeres vagy többszörös, változó számú és nagyságú, szemölcsös, bőrszínú vagy pigmentált növedéket észlelünk. Az esetek egy részében a szemölcsök a húgycső elülső szakaszában, a húgycsőnyílásban, a hüvely falán, a méhszájon és a végbélben is előfordulnak. Egyre gyakrabban találkozunk szájban, illetve száj körül megjelenő növedékekkel is.

A condyloma acuminatum szubjektív panaszokkal (fájdalom, viszketés stb.) többnyire nem jár, azonban a növedékek szaporodása, esztétikailag visszatetsző külleme előbb-utóbb orvoshoz viszi a beteget. A kezelés célja a növedékek eltávolítása, hiszen magát a HPV-fertőzést jelen tudásunk szerint gyógyítani nem lehetséges.

A fizikai, illetve a kémiai roncsoló kezelések után nem ritka a kiújulás, a választott kezeléstől függően akár 65\%-ban is számolhatunk a betegség kiújulásával [11]. A fizikai eltávolítás módszerei - kimetszés, fagyasztás, diathermiás vagy lézeres égetés - speciális eszközöket igényelnek.

A kémiai roncsoló kezelések szinte minden esetben erôs helyi gyulladásos reakciót váltanak ki duzzanat, vörösség, sebek, fekélyek kialakulásával, relatíve hosszadalmasak, és a kezelés utáni kiújulás az esetek mintegy harmadában várható [11].

A condyloma ellátása embert próbáló feladat mind az orvos, mind a beteg számára. A problémát súlyosbítja a betegség fertőző mivolta és terjedési módja, ami a beteg számára komoly pszichés tehertételt, a párkapcsolat számára pedig súlyos megpróbáltatást jelenthet $[3,5]$.

A következetes óvszerhasználat az anogenitalis condylomatosis kockázatát 60-70\%-kal képes csökkenteni. 
Az óvszer csupán azon a felületen véd, amit lefed, és tekintettel arra, hogy az anogenitalis bőr- és nyálkahártyafelület teljes kontinuuma barrier módszerrel nem védhető, ez egy limitált kapacitású védekezési lehetőség.

\subsubsection{Rekurráló respiratorikus papillomatosis}

A visszatérő gégepapillomatosist szintén fooleg a HPV 6-os és 11-es típusai idézik elő [12, 13]. Attól függően, hogy 12 éves kor előtt vagy után alakul-e ki, megkülönböztetjük fiatalkori és felnőttkori formáját. Előfordulhat akár rögtön születés után, de 84 éves betegnél is diagnosztizálták már. Az egyébként is gyakoribb fiatalkori esetek legnagyobb részét a gyermek ötéves koráig diagnosztizálják. Vezető tünetként a hangképzési zavart írják le. Minél korábban jelentkezik, annál nagyobb a valószínúsége a betegség progressziójának [13].

Retrospektív, majd prospektív vizsgálatok is igazolták, hogy a fertőzés forrása ezekben az esetekben az aktív, kiterjedt condyloma acuminatummal rendelkező anya, aki terhesség vagy szülés közben fertőzi meg gyermekét (vertikális fertőzés). Az anyai condyloma acuminatum megléte 231-szeresére növeli a visszatérő gégepapillomatosis kockázatát az újszülöttben [14].

A felnőttkori esetek általában 20 éves kor körül alakulnak ki. Nem tisztázott, hogy ezek az esetek egy újonnan (szexuális úton) szerzett HPV-fertőzés eredményei, vagy esetleg a születéskor szerzett HPV-fertőzés aktiválódásáról van-e szó a kórkép hátterében.

Az előfordulási gyakoriságra vonatkozó irodalmi adatok némileg eltérőek: 100000 lakosra vonatkoztatva az előfordulás 0,1 és 4 közé tehetô. Dán adatok alapján az előfordulási gyakoriság 3,62 (fiatalkori) és 3,94 (felnőttkori) 100000 lakosra vonatkoztatva, US-adatok alapján 4,3 (fiatalkori) és 1,8 (felnőttkori) 100000 lakosra vonatkoztatva $[13,15]$.

Hazánkban 2010. május és 2011. április között 230 új esetet (86 gyerek és 144 felnőtt) jelentettek. Jelenleg összesen 687 beteg áll gondozás alatt [16].

A visszatérő gégepapillomatosis egy rendkívül roszszul uralható betegség: a légutakban és az emésztőcsatornában szemölcsös daganatok alakulnak ki, amelyeket ismételt mútétekkel kell eltávolítani.

Annak ellenére, hogy a növedékek szövettanilag jóindulatúak, az állapot mégis rendkívül veszélyes, ugyanis a gyorsan növő tumorok elzárhatják a légutakat, és folyton kiújulnak.

A betegség lefolyása változó lehet: néha spontán remisszió is előfordulhat, vagy a betegség stabilizálódik, tehát egy idő után relatíve ritkábban kell mütéteket végezni. Azonban az esetek nagy részében gyakoriak a kiújulások, és hetente vagy akár néhány naponta el kell a növedékeket távolítani. A betegség óriási kihívás a kezelőorvos számára, komoly stresszt jelent a betegnek és családjának, és jelentős költségeket generál az egészségügyben $[12,13,15]$.

\section{Felhasznált irodalom}

[1] Lacey, C. J., Lowndes, C. M., Shah, K. V.: Chapter 4: burden and management of non-cancerous HPV-related conditions: HPV6/11 disease. Vaccine, 2006, 24 (Suppl. 3), S3/35-S3/41.

[2] Woodhall, S. C., Jit, M., Soldan, K., et al.: The impact of genital warts: loss of quality of life and cost of treatment in eight sexual health clinics in the UK. Sex. Transm. Infect., 2011.

[3] Maw, R. D., et al.: An international survey of patients with genital warts: perceptions regarding treatment and impact on lifestyle. Int. J. STD AIDS, 1998, 9 (10), 571-578.

[4] Woodhall, S., et al.: Estimation of the impact of genital warts on health related quality of life. Sex. Transm. Infect., 2008, 84 (3), 161-166.

[5] Mortensen, G. L., et al.: Quality of life of patients with condyloma. Ugeskr. Laeger, 2008, 170 (47), 3858-3862.

[6] Kliewer, E. V., Demers, A. A., Elliott, L., et al.: Twenty-year trends in the incidence and prevalence of diagnosed anogenital warts in Canada. Sex. Transm. Dis., 2009, 36, 380-386.

[7] Palefksy, J. M.: Human papillomavirus-related disease in men: not just a women's issue. J. Adolesc. Health, 2010, 46 (4), S12S19.

[8] Munk, C., Nielsen, A., Liaw, K., et al.: Genital warts in men: a large population-based cross-sectional survey of Danish men. Sex. Transm. Infect., 2012, 88, 640-644.

[9] Kjaer, S. K., Tran, T. N., Sparen, P., et al.: The burden of genital warts: a study of nearly 70,000 women from the general female population in the 4 Nordic countries. J. Infect. Dis., 2007, 196, 1447-1454.

[10] Winer, R. L., et al:: Genital human papillomavirus infection: incidence and risk factors in a cohort of female universitiy students. Am. J. Epidemiology, 2003, 157 (3), 218-226.

[11] Wiley, D. J., Douglas, J., Beutner, K., et al.: External genital warts: diagnosis, treatment, and prevention. CID, 2002, 35 (Suppl 2).

[12] Hartwig, S., Syrjänen, S., Dominiak-Felden, G., et al.: Estimation of the epidemiological burden of human papillomavirus-related cancers and nonmalignant diseases in men in Europe: a review. BMC Cancer, 2012, 12, 30.

[13] Larson, D. A., et al.: Epidemiology of recurrent respiratory papillomatosis. APMIS 2010, 118, 450-454.

[14] Silverberg, M. J., Thorsen, P., Lindeberg, H., et al.: Condyloma in pregnancy is strongly predictive of juvenile-onset recurrent respiratory papillomatosis. Obstet. Gynecol., 2003, 101, 645652.

[15] Novakovic, D., et al.: Estimating the prevalence of and treatment patterns for juvenile onset recurrent respiratory papillomatosis in Australia pre-vaccination: a pilot study. Sexual Health, 2010, 7, 253-261.

[16] ESKI TEA 


\subsection{A HPV okozta malignus és rekurráló megbetegedések terápiás költségeinek becslése}

\subsubsection{Megfontolások a humán papillomavirus (HPV) okozta kórképek betegségterhe kapcsán}

\subsubsection{Problémafelvetés}

A betegségteher-elemzések (disease burden analyses) arra tesznek kísérletet, hogy számszerüsítsék mindazon egészségügyi és társadalmi költségeket, amelyek egy adott megbetegedésre - avagy megbetegedést előidézó kockázati tényezőre, mögöttes faktorra - vezethetók vissza. Kiemelt szerepük, hogy tágabb perspektívában, az egyes társadalmi alrendszerek (például egészségügy, munkaügy, szociális ellátás, bűnmegelőzés) közötti kapcsolatokat figyelembe véve próbálják megbecsülni a betegség okozta direkt és indirekt költségeket, túllépve a finanszírozói nézőpontú elemzések időtávjából és látóköréből (scope) fakadó korlátokon.

A betegségteher-elemzésekben általában $3+1$ költségcsoportot lehet elkülöníteni, amelyeket - a vizsgálat terjedelmétól függően - koncentrikus körökként is ábrázolhatunk (1. ábra). A közvetlen egészségügyi költségek az adott betegség felismerésével, diagnosztikájával és kezelésével kapcsolatos ráfordításokat jelentik, amelyek az alap- és szakellátásban, valamint a gyógyszerelésben és az esetleg szükségessé váló támogató technológiákkal kapcsolatban jelentkeznek. A közvetett egészségügyi költségek közé elsődlegesen a szövődményköltségek tartoznak: azon megbetegedésekkel kapcsolatos egészségügyi ráfordítások, amelyek a fódiagnózisból kifejlődó egyéb kórképekkel, komorbiditásokkal függnek össze.

\section{Életminőség-romlás költségei}

Közvetett társadalmi költségek

Közvetett egészségügyi költségek

Közvetlen egészségügyi költségek

1. ábra

A betegségteher-elemzések szintjei
A szigorú értelemben vett társadalmi költségek az egészségügyi ellátáson kívüli alrendszerek ráfordításait fedik le: idetartozik például a munkából való kiesés (termelékenységveszteség), a beteget gondozó család járulékos költségei, valamint az esetleges devianciaköltségek. Az elemzések célja a társadalmi költségek tekintetében sokszor nem a pontos kalkuláció, hanem a költségtényező́k (cost drivers) feltérképezése és strukturálása. Végezetül az életminôség romlásából fakadó költségek - a szubjektív életminőség-romlás - azok, amelyek talán a legnehezebben számszerúsíthetők, és az objektivizálási erófeszítések ellenére a legkevésbé megragadhatók.

A betegségteher-elemzéseknek különösen azon kórképekben van jelentőségük, amelyek hosszú távú társbetegségek, szövődmények kialakulása révén befolyásolják a lakosság egészségügyi állapotát és/vagy amelyek esetében a korai felismerésnek és prevenciónak kiemelt jelentősége van. E betegségek közé tartoznak egyfelől a fiatalkori megbetegedések, másfelől a szövődményes infekciók, közöttük a humán papillomavírus (HPV) miatt kialakuló megbetegedések, amelyek írásunk szû́kebb tárgyát képezik. A HPV-vel összefüggésbe hozható kórképekre az elmúlt körülbelül 10 évben növekvő figyelem irányul, részben a népegészségügyi vonatkozások miatt, részben pedig azért, mert jelentős visszhangra leltek a szứrővizsgálatok és a profilaktikus védőoltás költséghatékonyságával, a célcsoport kiválasztásával kapcsolatos vizsgálatok (lásd: Dasbach, et al. 2010; Jit, et al. 2011). Egy, a HPV okozta megbetegedések megelőzésére kifejlesztett vakcina költséghatékonyságát vizsgáló tanulmányban a szerzók arra a következtetésre jutottak, hogy Magyarországon a 12 éves lányok számára kialakított rutin vakcinációs program (méhnyakrákszüréssel együtt) lényegesen visszaszoríthatja a méhnyakrák és rákmegelőző megbetegedések incidenciáját, már rövid távon csökkentheti a nemi szervi szemölcsök kialakulását, valamint jelentôsen javíthatja az életminőséget (Dasbach, et al., 2010).

A következőkben arra teszünk kísérletet, hogy felvázoljuk a HPV-vel összefüggő kórképek magyarországi betegségteher-elemzésének modelljét, azonosítsuk az elérhetó adatokat, megfogalmazzuk az ezek alapján leszűrhető következtetéseket, és rámutassunk azokra a pontokra, amelyek esetében további adatgyújtés és elemzés szükséges.

\subsubsection{HPV-vel összefüggésbe hozható kórképek} és előfordulási gyakoriságuk

A HPV-vel összefüggésbe hozható kórképek között meg kell különböztetni a rákos megbetegedéseket (ideértve a rákmegelőző állapotokat is), valamint a rekurráló betegségeket. A rákos megbetegedések közül a morbiditási statisztikákban a fej-nyaki rákok, valamint a méhnyakrák áll az élen; az anogenitalis rákok (peniscarcinoma, perianalis carcinoma, vagina- és vulvacarcinoma) előfordulási gyakorisága jóval alacsonyabb. A szakiroda- 
1. táblázat $\mid$ HPV-vel összefüggésbe hozható rákos és rekurráló betegségek gyakorisága. Forrás: Chaturwedi 2010, ESKI TEA, Goldstone-Vuocolo 2012, Mayeaux 2008, Nemzeti Rákregiszter, Parkin 2000, Parkin-Bray 2006, WHO - IVB 2007

\begin{tabular}{|c|c|c|c|c|c|c|}
\hline Kórkép & $\mathrm{BNO}$ & Gyakoriság & $\begin{array}{l}\text { HPV-korreláció } \\
(\%)\end{array}$ & $\begin{array}{l}\text { Incidencia } \\
\text { ( } 100000 \text { före) } \\
\text { a nemzetközi irodalom } \\
\text { alapján }\end{array}$ & $\begin{array}{l}\text { Incidencia (új esetszám) } \\
\text { Magyarországon } \\
\text { a rákbetegségek esetében } \\
\text { a Nemzeti Rákregiszter alapján }\end{array}$ & $\begin{array}{l}\text { Lejelentett } \\
\text { fekvőbeteg- } \\
\text { (bizonyos esetben: } \\
\text { járóbeteg-) } \\
\text { esetszám } \\
\text { Magyarországon } \\
\text { (2010. május- } \\
\text { 2011. április) }\end{array}$ \\
\hline Ajakrák & $\mathrm{C} 00$ & $\begin{array}{l}\text { Közepesen } \\
\text { gyakori, } \\
\text { fóként férfi }\end{array}$ & $3 \%$ & $\begin{array}{l}\text { 4/100 } 000 \text { férfi } \\
1 / 100000 \text { nő }\end{array}$ & $\begin{array}{l}\text { F: } \quad 176(2010) \\
\text { N: } \quad 35(2010)\end{array}$ & $\begin{array}{ll}\mathrm{F}: & 84 \\
\mathrm{~N}: & 16\end{array}$ \\
\hline Szájüregi rákok & $\begin{array}{l}\mathrm{C} 01, \mathrm{C} 02, \\
\mathrm{C} 03, \mathrm{C} 04, \\
\mathrm{C} 05, \mathrm{C} 06 \\
\mathrm{C} 07, \mathrm{C} 08\end{array}$ & $\begin{array}{l}\text { Gyakori, } \\
\text { föként férfi }\end{array}$ & $\begin{array}{l}\text { F: } 42 \% \\
\mathrm{~N}: 55 \%\end{array}$ & $\begin{array}{l}\text { 20/100 } 000 \text { férfi } \\
6 / 100000 \text { nő }\end{array}$ & $\begin{array}{l}\mathrm{F}: \quad 957(2010) \\
\mathrm{N}: \quad 309(2010)\end{array}$ & $\begin{array}{l}\mathrm{F}: 3618 \\
\mathrm{~N}: 963\end{array}$ \\
\hline Garatrák & $\begin{array}{l}\mathrm{C} 09, \mathrm{C} 10, \\
\mathrm{C} 11, \mathrm{C} 13, \\
\mathrm{C} 14\end{array}$ & $\begin{array}{l}\text { Gyakori, } \\
\text { fóként férfi }\end{array}$ & $35 \%$ & $\begin{array}{l}\text { 31/100 } 000 \text { férfi } \\
7 / 100000 \text { nő }\end{array}$ & $\begin{array}{l}\text { F: } 1500(2010) \\
\text { N: } 358(2010)\end{array}$ & $\begin{array}{l}\text { F: } 5652 \\
N: 916\end{array}$ \\
\hline Gégerák & C32 & $\begin{array}{l}\text { Gyakori, } \\
\text { fóként férfi }\end{array}$ & $\begin{array}{l}\text { F: } 40 \% \\
\text { N: } 18 \%\end{array}$ & $\begin{array}{l}\text { 24/100000 férfi } \\
4 / 100000 \text { nö }\end{array}$ & $\begin{array}{l}\text { F: } 1127(2010) \\
\text { N: } 206(2010)\end{array}$ & $\begin{array}{l}\text { F: } 3895 \\
\text { N: } 600\end{array}$ \\
\hline Nyelőcsőrák & C15 & $\begin{array}{l}\text { Gyakori, } \\
\text { fóként férfi }\end{array}$ & $37 \%$ & $\begin{array}{l}\text { 14-17/100000 férfi } \\
3-4 / 100000 \text { nő }\end{array}$ & $\begin{array}{l}\mathrm{F}: \quad 662-792(2001-2010) \\
\mathrm{N}: \quad 156-206(2001-2010)\end{array}$ & $\begin{array}{l}\text { F: } 2057 \\
\text { N: } 424\end{array}$ \\
\hline Méhnyakrák & C53 & Gyakori & $99-100 \%$ & 15-30/100 000 nő & $\mathrm{N}: \quad 900-1000(2001-2010)$ & $\begin{array}{l}\text { F: } \quad 0 \\
N: 4013\end{array}$ \\
\hline Peniscarcinoma & $\mathrm{C} 60$ & Igen ritka & $40 \%$ & $1 / 100000$ férfi & $56-85(2001-2010)$ & $\begin{array}{lr}\mathrm{F}: & 92 \\
\mathrm{~N}: & 0\end{array}$ \\
\hline Perianalis carcinoma & $\mathrm{C} 21$ & Igen ritka & $90 \%$ & $\begin{array}{l}\mathrm{F}: \quad 0,5-0,8 / 100000 \\
\mathrm{~N}: 0,5-1,2 / 100000\end{array}$ & $\begin{array}{l}\mathrm{F}: \quad 75-110(2001-2010) \\
\mathrm{N}: \quad 68-128(2001-2010)\end{array}$ & $\begin{array}{ll}\mathrm{F}: & 244 \\
\mathrm{~N}: & 250\end{array}$ \\
\hline $\begin{array}{l}\text { Vagina- és vulva- } \\
\text { carcinoma }\end{array}$ & C51, C52 & Igen ritka & $40 \%$ & $0,5-1,5 / 100000$ nő & $\mathrm{N}: \quad 75-107(2001-2010)$ & $\begin{array}{lr}\text { F: } & 0 \\
\mathrm{~N}: & 868\end{array}$ \\
\hline $\begin{array}{l}\text { Condyloma } \\
\text { acuminatum }\end{array}$ & $\begin{array}{l}\text { B9770, } \\
\text { A6300 }\end{array}$ & Gyakori & $90-100 \%$ & 4000-7000/100 000 nő & $\begin{array}{l}\text { Nem áll rendelkezésre külön } \\
\text { magyarországi adat }\end{array}$ & $\begin{array}{l}\text { Fekvőbeteg-ellátás } \\
\text { F: 0, N: } 294 \\
\text { Járóbeteg-ellátás } \\
\text { F: } 4630, \mathrm{~N}: 9498\end{array}$ \\
\hline Gégepapillomatosis & D1410 & Igen ritka & $100 \%$ & $1,8-4,3 / 100000$ fó & $\begin{array}{l}230 \\
(86 \text { gyermek, } 144 \text { felnőtt) }\end{array}$ & $\begin{array}{l}\text { Fekvőbeteg-ellátás } \\
\text { F: } 51, \mathrm{~N}: 21 \\
\text { Járóbeteg-ellátás } \\
\text { F: } 435, \mathrm{~N}: 252\end{array}$ \\
\hline
\end{tabular}

lomban számos, igen eltérő becslés található a HPVpozitivitás és az egyes ráktípusok közötti korreláció erősségéről. A méhnyakrák esetében a korreláció gyakorlatilag 100\%-os, a többi kórkép esetében alacsonyabb, az egyre újabb és újabb vizsgálatok azonban mind szorosabb összefüggéseket tárnak fel. Az anogenitalis rákok és a HPV közötti korrelációt 40-90\% közé tehetjük. A fej-nyaki rákok esetében a koefficiens a fejlett országokban 10-30\% közötti, Kelet-Közép-Európában azonban inkább a 20-50\%-os tartomány a jellemző. A rekurráló megbetegedések között az enyhe betegségnek számító, de sokakat érintő condyloma acuminatumot (nemi szervi szemölcs), valamint az életminőséget súlyosan rontó, fertőzött anya által a magzatnak is átadható gégepapillomatosist kell említeni. Az 1. táblázat áttekintést ad az incidenciaadatokról, esetszámokról és a HPV-korrelációról, a 2. ábra pedig azt mu- tatja, hogy az egyes megbetegedésekért jellemzően mely HPV-vírustörzsek felelősek.

\subsubsection{Betegségteher: adatok és bizonytalanságok}

Nincs tudomásunk arról, hogy a HPV-fertőzéssel öszszefüggő kórképek társadalmi terhét összefoglalóan bemutató tanulmány készült volna Magyarországon. Brandtmüller Ágnes és munkatársai 2008-as konferencia-előadásukban a méhnyakrák és a méhnyakrák-megelőző állapotok közvetlen egészségügyi ellátási költségeit éves szinten 1,44 milliárd forintnak becsülték az Országos Egészségbiztosítási Pénztár (OEP) finanszírozási adatbázisai alapján, figyelembe véve a járóbeteg-szakellátásban, az aktív és krónikus fekvőbetegszakellátásban a releváns BNO-kódokra lejelentett teljesítmények mellett a CT/MRI diagnosztikai költségeket 


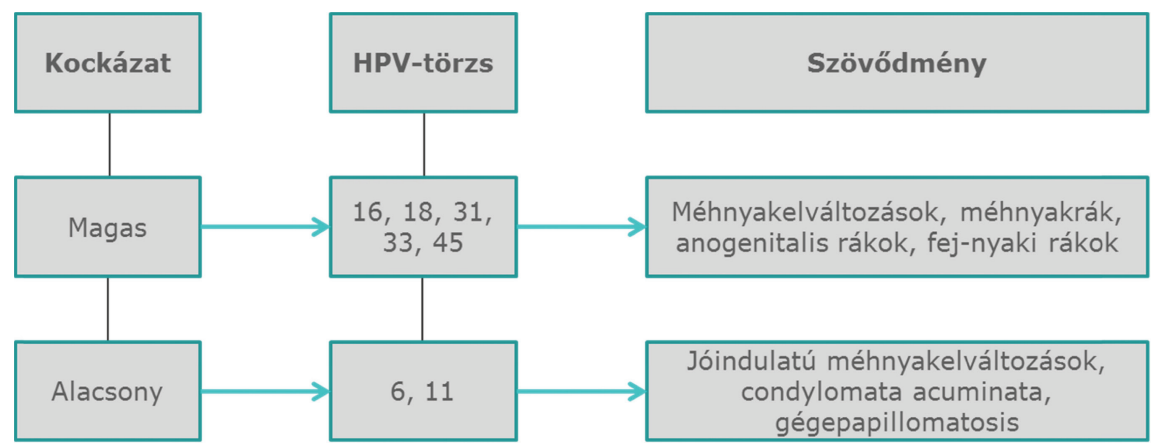

2. ábra

| Az egyes HPV-törzsekre visszavezethető szövődmények. Forrás: Mayeaux 2008

2. táblázat | HPV-vel összefüggésbe hozható megbetegedések közvetlen ellátási költsége Magyarországon, incidenciaalapú megközelítésben. Forrás: saját számítások, a Nemzeti Rákregiszter adatai alapján (a módszertani megfontolásokhoz lásd a Végjegyzeteket)

\begin{tabular}{|c|c|c|c|c|c|c|c|c|c|c|c|}
\hline & 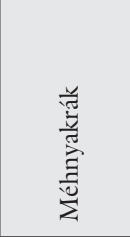 & 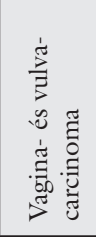 & 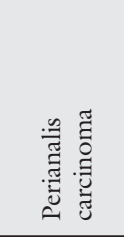 & 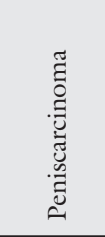 & 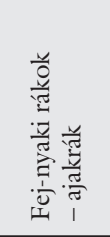 & 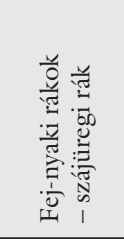 & 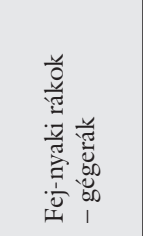 & 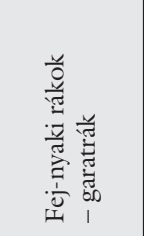 & 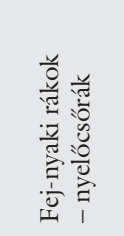 & 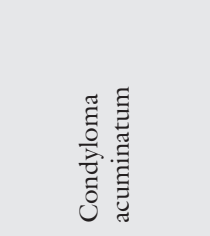 & 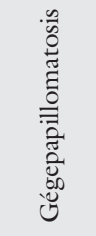 \\
\hline $\begin{array}{l}\text { Esetszám } \\
(2010)\end{array}$ & 932 & 107 & $\begin{array}{l}110+128 \\
=238\end{array}$ & 85 & $\begin{array}{l}176+35 \\
=211\end{array}$ & $\begin{array}{l}957+309 \\
=1266\end{array}$ & $\begin{array}{l}1127+206 \\
=1333\end{array}$ & $\begin{array}{l}1500+358 \\
=1858\end{array}$ & $\begin{array}{l}792+206 \\
=998\end{array}$ & \multirow{5}{*}{$\begin{array}{l}\text { Hazai } \\
\text { incidenciaadatok } \\
\text { hiányában nem } \\
\text { vizsgáljuk }\end{array}$} & 230 \\
\hline $\begin{array}{l}\text { HPV okozta } \\
(\%)\end{array}$ & $99-100 \%$ & $40 \%$ & $90 \%$ & $40 \%$ & $3 \%$ & $42-55 \%$ & $18-40 \%$ & $35 \%$ & $37 \%$ & & $100 \%$ \\
\hline $\begin{array}{l}\text { HPV okozta } \\
\text { esetszám }\end{array}$ & 932 & 43 & 214 & 34 & 6 & 572 & 489 & 650 & 369 & & 230 \\
\hline $\begin{array}{l}\text { Egy eset } \\
\text { ellátási } \\
\text { költsége } \\
(\text { E Ft) }\end{array}$ & 1102,0 & 227,0 & 1226,0 & 490,0 & 1305,0 & 1305,0 & 1305,0 & 481,0 & 1577,0 & & 322,0 \\
\hline $\begin{array}{l}\text { Teljes költség } \\
\text { (E Ft) }\end{array}$ & $\begin{array}{l}\text { Kb. } \\
943031\end{array}$ & $\begin{array}{l}\text { Kb. } \\
9767\end{array}$ & $\begin{array}{l}\text { Kb. } \\
262330\end{array}$ & $\begin{array}{l}\mathrm{Kb} . \\
16660\end{array}$ & \multicolumn{4}{|c|}{ Kb. 1705085} & $\begin{array}{l}\text { Kb. } \\
584000\end{array}$ & & $\begin{array}{l}\text { Kb. } \\
74060\end{array}$ \\
\hline
\end{tabular}

is, mindezt a 2004. január 1. és 2004. december 31. közötti időszakra vonatkoztatva. Elemzésük nem tért ki ugyanakkor a közvetett egészségügyi és társadalmi költségekre.

Jelen közlemény szerzői a HPV okozta rákos és rekurráló megbetegedések közvetlen egészségügyi ellátási költségének becslésére a HPV okozta megbetegedések diagnosztikája és kezelése során felmerülő beavatkozások finanszírozási díjtételei, valamint egyfelől a Nemzeti Rákregiszter 2010. évi új esetszámai (incidenciaadatai), másfelől az OEP felé a 2010. május és 2011. április közötti 12 hónapos időszakban lejelentett betegszámok (prevalencia jellegú megközelítés) alapján tettek kísérletet. A finanszírozási díjtételeket mindkét megközelítésben a 2011. évi, járóbeteg- és fekvőbetegellátásban érvényes paraméterek szerint szerepeltetik. A kapott eredményeket a 2. és 3. táblázatok mutatják - ezek egyéves időtávra vonatkoznak. Hazai incidenciaadatok hiányában a condyloma acuminatum esetében az incidenciaalapú megközelítést nem vizsgáljuk.

Tételes finanszírozási adatok hiányában az eredmények szükségszerüen pontatlanok: nem biztos (noha a kezelőintézmények gazdasági racionalitása így diktálná), hogy a betegek esetében ténylegesen minden elvégzendő vizsgálat és beavatkozás elszámolásra kerül. $\mathrm{Az}$ incidenciaalapú megközelítés a valós egészségügyi ellátási költségeket inkább alulbecsüli (mivel csak az új betegeket veszi figyelembe), a prevalenciaalapú megközelítés pedig inkább túlbecsüli (a nem szükségszerü, s emiatt el nem végzett beavatkozások okán). A számítások finanszírozói perspektívából készültek, így eltekintenek a betegek által teljesített esetleges magánjellegü és informális fizetésektől. A HPV-re visszavezethető esetszám becslésekor mindvégig a konzervatívabb adatokat használjuk.

A fenti adatokból látható, hogy a legnagyobb közvetlen egészségügyi ellátási költséget a fej-nyaki rákok, valamint a méhnyakrák okozzák. E betegségek - más, HPV-vel összefüggő rákos megbetegedéshez képest vett - tehernagyságának elsődleges oka a magasabb betegszám. Az egy esetre vonatkozó ellátási költség jóval szúkebb sávban ingadozik a vizsgált betegségek esetében, mint az előfordulási gyakoriság. Az incidenciaalapú megközelítésben a fej-nyaki rákokra, valamint a méh- 


\begin{tabular}{|c|c|c|c|c|c|c|c|c|c|c|c|}
\hline & $\frac{\frac{y}{\pi}}{\frac{\sqrt[3]{3}}{3}}$ & 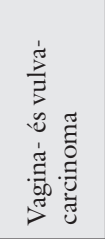 & 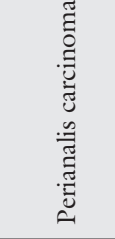 & 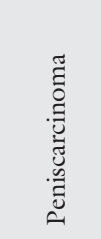 & 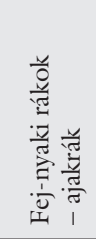 & 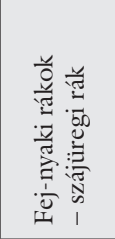 & 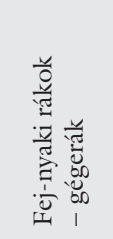 & 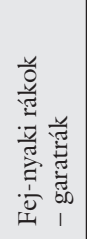 & 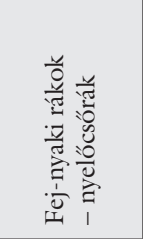 & 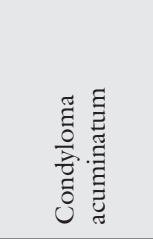 & 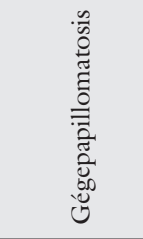 \\
\hline Esetszám (2010) & 4013 & 868 & 494 & 92 & 100 & 4581 & 4495 & 6568 & 2481 & $\begin{array}{l}9498 \\
\text { (járóbeteg- } \\
\text { betegszám) }\end{array}$ & $\begin{array}{l}687 \\
\text { (járóbeteg- } \\
\text { betegszám) }\end{array}$ \\
\hline HPV okozta (\%) & $100 \%$ & $40 \%$ & $90 \%$ & $40 \%$ & $3 \%$ & $42-55 \%$ & $18-40 \%$ & $35 \%$ & $37 \%$ & $90-100 \%$ & $100 \%$ \\
\hline HPV okozta esetszám & 4013 & 347 & 445 & 37 & 3 & 2061 & 1663 & 2299 & 918 & 8548 & 687 \\
\hline $\begin{array}{l}\text { Egy eset ellátási } \\
\text { költsége (E Ft) }\end{array}$ & 977 & 227 & 1226 & 490 & 1305 & 1305 & 1305 & 481 & 1577 & 6,8 & 322 \\
\hline Teljes költség (E Ft) & $\begin{array}{l}\text { Kb. } \\
3922774\end{array}$ & $\begin{array}{l}\text { Kb. } \\
78868\end{array}$ & $\begin{array}{l}\text { Kb. } \\
545010\end{array}$ & $\begin{array}{l}\mathrm{Kb} . \\
18129\end{array}$ & \multicolumn{4}{|c|}{ Kb. 5969554} & $\begin{array}{l}\text { Kb. } \\
1447886\end{array}$ & $\begin{array}{l}\text { Kb. } \\
58127\end{array}$ & $\begin{array}{l}\text { Kb. } \\
221214\end{array}$ \\
\hline
\end{tabular}

nyakrákra fordított egészségbiztosítói kiadások együttesen évi 2,8-2,9 milliárd forintra becsülhetők. A méhnyakrák vonatkozásában kapott kb. 1,0 milliárd forint/ év adat összhangban van Brandtmïller és munkatársai 2008-as munkájával, mivel saját számításainkban a méhnyakrák-megelőző állapotokat nem vettük figyelembe. Incidenciaalapú megközelítésben a HPV okozta rákos és rekurráló megbetegedések közvetlen egészségügyi költsége éves szinten 2011-ben meghaladta a 3,9 milliárd forintot, aminek messze túlnyomó többségét a carcinomák kezelésére fordított források jelentették. Prevalenciaalapú megközelítésben a közvetlen egészségügyi ellátási költségek is magasabbnak adódnak: becsléseink szerint meghaladják az évi 14,0 milliárd forintot, amelynek jelentős részét itt is a fej-nyaki rákok és a méhnyakrák kezelése teszi ki. A prevalenciaalapú megközelítéssel kapcsolatban megemlítendő a condyloma acuminatum kérdése: a közvetlen ellátási költségek azért adódnak alacsonynak, mert elenyésző az orvoshoz forduló, felismert betegek aránya (körülbelül évi 10000 járóbeteg-eset a 400-700 ezer fós vélelmezhetó populációhoz képest). Ennek elsősorban a közvetett költségekre lesz jelentős hatása.

A közvetlen egészségügyi ellátási költségek átfogóbb, illetve pontosabb elemzésnek akadályát jelenti, hogy az OEP finanszírozási adatbázisai nyilvánosan nem hozzáférhetók; az intézményeknek ténylegesen kifizetett finanszírozási díjtételek pénzért, több hónapos átfutási idő után válnak csak elemezhetővé. A későbbiekben ugyanakkor indokolt lehet a Brandtmüller és munkatársai által végzett vizsgálat reprodukálása az OEP által ténylegesen ellentételezett 2011. évi szolgáltatói teljesítmények alapján, hogy a két eredmény közvetlenül összevethető lehessen egymással.

A bemutatott direkt egészségügyi költségeken túl a HPV-fertőzésre visszavezethető betegségek számos indirekt társadalmi költséggel is járnak. Noha itt nem lehet célunk ezek számszerúsítése, az egyes megbetegedésekhez kapcsolódó legspecifikusabb indirekt költségtényezőket lehatároljuk. A HPV-pel korreláló rákfajták esetében jelentős költségeket okoznak a következők: a beteg és/vagy az otthoni ellátásban segédkezô családtagjának munkaerôpiacról való kiesése, termelékenységcsökkenése a betegség éveire vonatkoztatva, továbbá a nyugdíjas kor elôtt bekövetkező halál esetén a gazdaság számára elvesztett, a bruttó hazai termékhez hozzáadott érték. Nem hagyhatók figyelmen kívül a méhnyakon végzett, a méhszáj záróstruktúráját károsító mútéteknek a fertilitásra gyakorolt kedvezőtlen hatásai sem. A rákmegelőző állapotok és a korai méhnyakrák miatt végzett mútétek meddőséget eredményezhetnek, és teherbe esés esetén is magasabb a vetélések, éretlen újszülöttek, valamint a koraszülések aránya. Ez rövid távon a természetes szaporulatot, hosszabb távon - a meg nem született aktív munkaeró ténye miatt - a nemzetgazdaság produktivitását csökkenti.

A HPV okozta rekurráló megbetegedések indirekt költségei a condyloma acuminatum esetében elsősorban az időlegesen kieső munkaerő hozzáadottérték-veszteségébőll, illetve a szégyenérzet miatti improduktivitásból adódó termelékenységcsökkenésből adódnak. A komplexusérzés szexuális tevékenységbe való begyúrúzése miatti tervezett gyermekvállalás elmaradása is társadalmi indirekt költségként jelenik meg. A társadalmi terhet növelik a kezeletlen betegek több partnerrel folytatott kapcsolatai - felmérések szerint például egy magyar nő élete során 9,5 szexuális partnerrel kerül kapcsolatba (GSS, 2004). A gégepapillomatosis indirekt költségei a huzamos időre kieső, improduktívvá váló munkaerő nemzetgazdasági veszteségeiből, továbbá beteg gyermek esetén a gondozás és otthon maradás költségeiből tevődnek össze. A gyermek szégyenérzete és a betegség idejére - a korának megfelelő - szociális kapcsolataiból való kiesése a későbbi szocializációjára 
4. táblázat | HPV-vel összefüggésbe hozható kórképek magyarországi betegségterhéról rendelkezésre álló elemzések

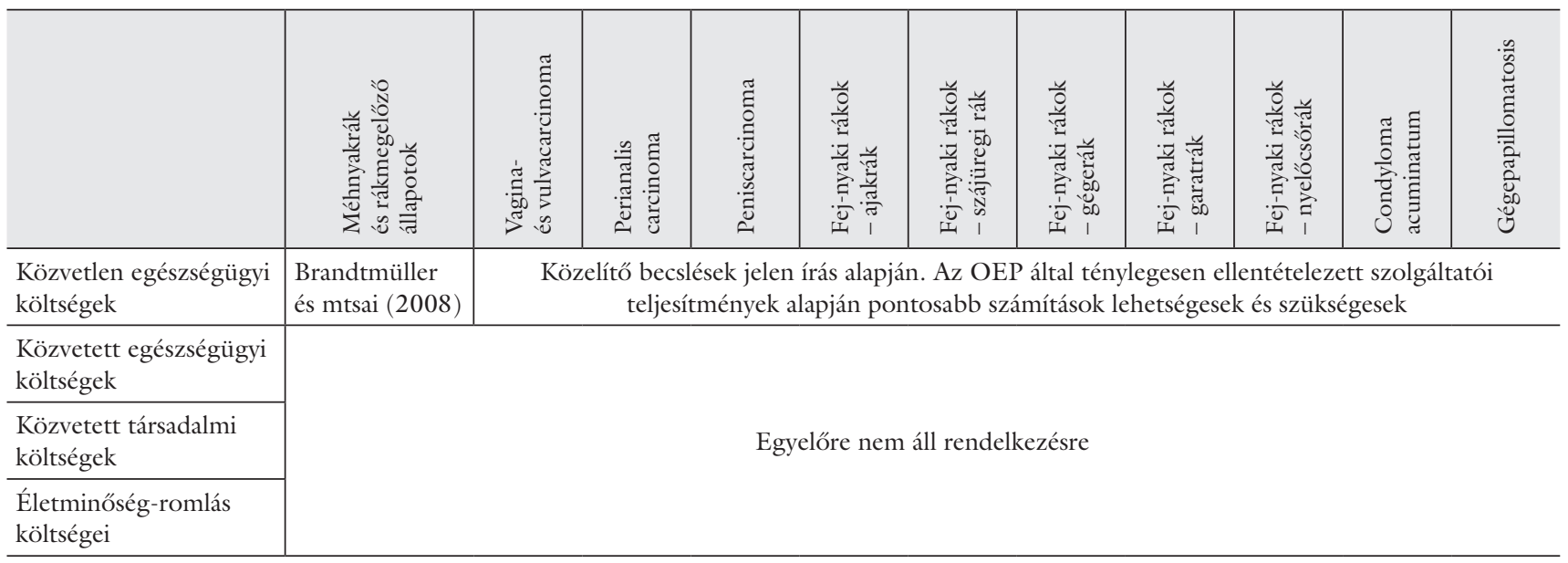

nyomhatja rá a bélyegét; ez a későbbi tanulási folyamat, végeredményben a humán tőke, a munkaerő-piaci beilleszkedés kapcsán járhat káros következményekkel.

Összefoglalva mindezeket, továbbá kitérve a közeljövőben célszerüen elvégzendő elemzési feladatokra, azt látjuk, hogy a HPV-vel összefüggésbe hozható teljes betegségtehernek egyelőre viszonylag kis szegmensét tudjuk pontosan becsülni. Helyes képet akkor kapnánk, ha a különböző rákos kórképek, valamint rekurráló betegségek közvetett egészségügyi és társadalmi költségeit is figyelembe tudnánk venni, azonban egy-egy ilyen modell elkészítése több hónapos munkát igényelhet. A 4. táblázat összefoglaló jelleggel mutatja a jelenleg elérhető elemzéseket.

\subsubsection{Trendek}

Mayeaux (2008) és Chaturwedi (2010) elemzései szerint a HPV-fertőzések kordában tarthatók ugyan, s ez a fejlett országokban egyelőre sikerül is, de a kockázati faktorok súlyának növekedését csak jól megszervezett szúróprogramok és profilaktikus vakcináció ellensúlyozhatják. A közepes jövedelmű országokban - s Magyarország az egészségügyi ellátórendszer múködési minősége tekintetében inkább ezekhez áll közel - a HPV okozta fenyegetés egyre erôsödik, mivel a HPV-szűrések intézményi háttere nem tart lépést a kockázati tényezők fokozódásával. Ezek között a méhnyakrák kapcsán elsődlegesen a szexuális partnerek számának megnövekedését (négy-öt partnernél több), a szexuális élet megkezdésének korábbra (16 év előtti korra) helyeződését, az azonos nemú partnerek közötti szexuális kapcsolatot, a körülmetéletlen péniszt, valamint nők esetében a férfi partner korábbi promiszkuitását szokás említeni, ám a szakirodalom utal a hormonális fogamzásgátló terápiák, az étrend, valamint a párhuzamos genitalis fertőzések (például herpes, chlamydia) szerepére is. A fej-nyaki tumorok kapcsán megfigyelhető a HPV-vel kapcsolatba hozható megbetegedések incidenciájának növekedése, miközben a HPV-független esetek előfordulási gyako- risága csökkenő trendet mutat (Bosch, et al. - 2002; Chaturwedi 2010; Dasbach, et al. 2010; Donovan, et al. 2011; Insinga 2004; Lacey 2007; Mayeaux 2008; Parkin-Bray 2006; WHO-ICO 2007). E szempontból elsődlegesen a fejlettebb országokban élő férfiak jelentik a kiemelt kockázati csoportot, míg az alacsonyabb jövedelmú társadalmakban továbbra is a dohányzás marad az elsődleges prognosztikai faktor.

A HPV-fertőzés és a méhnyakrák jelentkezése között 10-20 év is eltelhet, így a kockázati tényezők közül a szexuális magatartás átrendeződése a fiatalkori szex, illetve a magasabb partnerszám irányába felveti annak eshetőségét, hogy a közepes jövedelmű országokban - megfelelő népegészségügyi intézkedések hiányában egy-két évtized távlatában a méhnyakrák hirtelen előretörésével szembesülünk (WHO-ICO 2007). Ezzel szemben a HPV indukálta fej-nyaki tumorok látszólag a magasabb jövedelmű országokban fognak fenyegetést jelenteni, és a dohányzás mint társadalmi jelenség visszaszorulásával párhuzamosan relatíve több figyelmet kell majd rájuk fordítani (Chaturwedi 2010; Herrero 2003). Azt megbecsülni, hogy a kockázati tényezők előtérbe kerülése pontosan mekkora mértékben növelheti az egészségügyi ellátási költségeket, meglehetősen bizonytalan feladat, szinte bizonyosra vehetjük ugyanakkor, hogy a HPV-profilaxis költséghatékonysága az elkövetkező időszakban még dominánsabbá fog válni az ajánlásokban szereplő 12 éves leányok kohorsza esetében.

\section{Felhasznált irodalom}

[1] Brandtmüller, A., Erdész, D., Nagy, L.: A méhnyakrák és méhnyakrák-megelőző állapotok járóbeteg- és kórházi ellátási költsége Magyarországon. IME-META konferencia, 2008. július 9.

[2] Chaturwedi, A. K.: HPV and incidence trends for head and neck cancer. National Cancer Institute 2010. URL: http://www. thelancetconferences.com/hpv-and-cancer/presentations/ chaturvedi_presentation.pdf. Letöltve: 2012.06.01. 
[3] Dasbach, E. J., Nagy, L., Brandtmüller, A., et al.: The cost effectiveness of a quadrivalent human papillomavirus vaccine $(6 / 11 /$ 16/18) in Hungary. Journal of Medical Economics, 2010, 13 (1), 110-118

[4] Donovan, B., et al.: Quadrivalent human papillomavirus vaccination and trends in genital warts in Australia: analysis of national sentinel surveillance data. Lancet Infectious Diseases, 2011 (11), 39-44.

[5] Durex Global Sex Survey 2004, Result Report.

[6] Giuliano, A. R. et al.: Epidemiology of human papillomavirus infection in men, cancers other than cervical and benign conditions. Vaccine, 2008, 26 (Suppl. 10), k22-k25.

[7] Goldstone, S. E., Vuocolo, S.: A prophylactic quadrivalent vaccine for the prevention of infection and disease related to HPV-6, $-11,-16$ and -18. Expert Rev. Vaccines, 2012, 11 (4), 395-406.

[8] Herrero, R., et al.: Human papillomavirus and oral cancer: the International Agency for Research on Cancer multicenter study. J. Natl. Cancer Inst., 2003, 95 (23), 1772-1783.

[9] Insinga, R. P.: The health care costs of cervical human papillomavirus-related disease. Am. J. Obstet. Gynecol., 2004, 191, 114-120.

[10] Kásler, M.: Klímaváltozás és a fej-nyaki onkológia. Magyar Tudomány, 2011, 2, 154-160.

[11] Lacey, C. J. N., et al.: Burden and management of non-cancerous HPV-related conditions: HPV-6/11 disease. Vaccine, 2006, 24 (suppl 3), 35-41.

[12] Lehtinen, M.: Time trends in incidence and prevalence of human papillomavirus type 6,11 and 16 infections in Finland. Journal of General Virology, 2003, 84, 2105-2109.

[13] Mark, H. B., Robert, B.: MSD Orvosi kézikönyv. Diagnózis és terápia. Budapest, Melania Kiadó Kft., 1999.

[14] Mayeaux, M. J.: Reducing the Economic Burden of HPV-Related Diseases. J. Am. Osteopath. Assoc., 2008, 108 (suppl 2), S2-S7.

[15] Ottó, Sz., Kásler, M.: Rákmortalitás és -incidencia hazánkban, az európai adatok tükrében. Magyar Onkológia, 2002, 46 (2), 111-117.

[16] Parkin, D. M.: The global health burden of infection-associated cancers in the year 2000. Int. J. Cancer, 2006, 118 (12), 3030-3044

[17] Parkin, D. M., Bray, F.: The burden of HPV-related cancers. Vaccine, 2006, 24S3, S3/11-S3/25.

[18] Szentirmay, Z., Ottó, Sz., Kásler, M.: A humán papillomavírus (HPV) molekuláris biológiai meghatározásának indikációi. Magyar Onkológia, 2002, 46, 235-237.

[19] Szentirmay, Z., Szántó, I., Bálint, I., et al.: Oki összefüggés a humán papillomavírus-fertőzés és a fej-nyaki régió, valamint a nyelőcső laphámrákjának egyes típusai között. Magyar Onkológia, 2012, 46, 35-41.

[20] Walboomers, J. M., et al:: The current status of development of prophylactic vaccines against human papillomavirus infection. J. Pathol., 1999, 189, 12-19.

[21] WHO-ICO: Human papillomavirus and cervical cancer - Summary Report Hungary, 2007.

[22] http://www.ksh.hu/docs/hun/xtabla/nepmozg/tablnepl l _04.html

[23] WHO-IVB. Human papillomavirus and HPV vaccines: technical information for policy-makers and health professionals, 2007.

\section{Végjegyzetek}

Méhnyakrák: A betegség felismerése kapcsán a cervicalis kenetvétellel és a festett kenetben lévő hüvelyváladék vizsgálatával számoltunk, továbbá csak a szúréseken kiszűrt páciensek számával kalkuláltunk a kenetvétel és a vizsgálat elenyésző költségei miatt. A petefészekrák korai diagnosztizálási arányának analógiájára a méhnyakrákos betegek negyedrésze kapcsán éltünk azzal a feltételezéssel, hogy a betegek korai stádiumban fordulnak orvoshoz, így esetükben a célzott mellkasfelvétel kiegészítő vizsgálata is szükséges, illetve natív és iv. kontrasztanyag adását követően a teljes has és medence CT- vagy MRvizsgálata is elvégezhető (kalkulációnkban ez utóbbiakat fele-fele arányban szerepeltettük). A kezelések költségkalkulációja kapcsán az I-II.A, valamint a II.B-IV. stádiumokban lévő betegek számát illetően 20-80\%-os eloszlást feltételeztünk. (Az I-IV. stádiumba tartozók ötéves túlélési valószínűsége alapján az öt évvel később meghaltak számának stádiumokba történő beosztása, majd ennek az aránynak az egész, még életben lévő betegcsoportra történő alkalmazása alapján.) Az I-II.A stádiumban lévő beteg kezelése kapcsán cervixmútéttel és sugárterápiával számoltunk, a II.B-IV. stádiumok 60\%-ában csak sugárkezeléssel (a daganatok 40\%-ánál eredménytelen a radioterápia), 20\%-ban a radioterápia utáni sikeres malignus folyamatokban végzett nőgyógyászati kis mútéttel, a maradék 20\%-ban a radioterápia utáni eredménytelen malignus folyamatokban végzett nőgyógyászati kis mútéttel és (CDDP/B protokoll szerinti) négy fázis rosszindulatú daganat esetén kombinált sugár- és gyógyszeres „C” kezeléssel kalkuláltunk.

Vagina- és vulvacarcinoma: A vaginacarcinoma felismerésének költségkalkulációjában a szokásos feldolgozási módszerrel történő szövettani vizsgálat, míg a vulvacarcinoma kapcsán a kismedence transvaginalis ultrahangos vizsgálat, a cervicalis kenetvételhez és a festett kenetben történő hüvelyváladék-vizsgálat beavatkozási költségeit vettük alapul. A hüvelydaganat kezelésének számszerúsítéséhez nagyrészt (80\%-ban, a méhnyakrákos betegek betegségstádium szerinti eloszlásszámításnál alkalmazott módszertan alapján) a sugárterápia költségét vettük alapul, kisebb részben (20\%-ban) pedig a vagina kimetszésének költségével kalkuláltunk. A vulvacarcinoma kezelésének kalkulációja kapcsán a nem előrehaladott esetben (20\%) vulvamútét költségével, míg az előrehaladott esetben rosszindulatú daganat esetén kombinált sugár- és gyógyszeres „E” (FEC+dexrazoxan protokoll szerint) kezelés egy fázisának költségével számoltunk.

Perianalis carcinoma: A felismerés költségszámítása általános gasztroenterológiai vizsgálat, szövettani mintavétel, endoszkópos ultrahangvizsgálat, tükrözés, illetve CTvizsgálatok beavatkozási költségeinek figyelembevételével történt. A kezelés költségkalkulációjánál a „rectumreszekció társult betegséggel”, a „sugárterápia”, továbbá „rosszindulatú daganat esetén kombinált sugár- és gyógyszeres „A” kezelés öt fázisának („Radiokemoterápia anális rák esetén 5FU-MMC protokoll szerint)" fekvőbeteg-ellátási költségeit vettük alapul a méhnyakráknál is alkalmazott betegszámeloszlás módszertanának felhasználásával.

Penisrák: A felismerésnél alkalmazott ellátások a következők: „biopsia penis”, „hasi (áttekint”, komplex) ultrahangvizsgálat” és „teljes has és medence MR-vizs- 
gálata natív plusz iv. kontrasztanyag adását követően”. Kezelésnél a HBCs-besorolás alapján a rosszindulatú daganat esetén a súlyos társult betegséggel járó férfi szaporító/nemi szerv mútéteit, illetve az amputációt, továbbá a rosszindulatú daganat C" kezeléssel történő kemoterápiát $(\mathrm{CDDP}+5 \mathrm{FU} / \mathrm{D}$ protokoll szerint egy fázis) vettük figyelembe (80-20\%-os betegszámmegoszlással).

Fej-nyaki rákok, kivéve nyelöcsörák: A felismerés kapcsán száj-garat-gége esetében az alábbi kezeléseket vettük figyelembe: átfogó vizsgálat, laborvizsgálat, biopsziát, rhino-pharyngo-laryngo-fiberoszkópiát, röntgenfelvételt, radiographia dentalis panoramicát, arckoponya CT- és MR-vizsgálatát natív plusz kontrasztanyag adását követően vettük figyelembe. A kalkuláció során a súlyos betegséggel társult fül-, orr-, torok-, gége-, szájmütéteket (kivéve: nagyobb fej-nyaki mütétek rosszindulatú daganat miatt), sugárterápiát, valamint a kombinált sugár- és gyógyszeres „A” kezelést hét fázissal (fej-nyaki rák esetén $\mathrm{CDDP}$ és $\mathrm{CDDP}+5 \mathrm{FU}$ protokoll szerint), illetve a garatráknál egy fázissal a rosszindulatú daganat "H” kemoterápiáját (TPF-protokoll szerint) és azok kombinációját vettük figyelembe a vonatkozó HBCs-súlyszámok és költségeik szerint, illetve azok egyenletes eloszlását feltételeztük a betegek körében. Ajakrák esetében átfogó vizsgálat, CT, röntgen, ultrahang, biopszia és egy fázissal a rosszindulatú daganat „H” kemoterápiája (TPF-protokoll szerint) került elszámolásra.

Nyelöcsörák: A felismerésnél a következőket vettük figyelembe: biopszia, az organikus nyelőcsőszúkület endoszkópos szondatágítása, illetve ennek kizárása esetén (a betegek felénél ezt feltételeztük) a nyelősső kontrasztanyaggal történő röntgenvizsgálata, továbbá célzott mellkasfelvétel és végül vérkép elemzése. A kezelésnél a „fül-, orr-, torok-, gége-, szájmütétek (kivéve: nagyobb fej-nyaki mútétek rosszindulatú daganat miatt) súlyos társult betegséggel" HBCs szerinti költsége és a kombinált sugár- és gyógyszeres „A” kezelés hét fázissal (fej-nyaki rák esetén CDDP-protokoll és fej-nyaki rák esetén CDDP+5FU protokoll szerint), továbbá ez utóbbi és a sugárkezelés kombinációjának - HBCs szerinti - költsége került elszámolásra a kalkulációban fele-fele megoszlású betegszámmal.

Condyloma acuminatum: A felismerés esetében az orvoshoz fordulási alacsony hajlandóság miatt nem szerepeltettünk a felismeréshez kapcsolódó beavatkozási költségeket, azok elhanyagolható mértéke miatt. A kezelés kapcsán a férfi szaporító/nemi szerv lézeres mútéti költségeit és a kis sebészeti beavatkozások költségeit számszerüsítettük 1-99\%-os betegeloszlási aránnyal.

Gégepapillomatosis: A felismerésnél laringoszkópiás vizsgálatot, a kezelésnél a rosszindulatú daganat miatti fej-, nyaktájék egyéb nagyobb mütét HBCs szerinti költségeit vettük alapul. 


\section{2. \\ A HPV okozta \\ malignus és rekurráló megbetegedések megelőzésére szolgáló vakcinák}

\subsection{A HPV-vakcinák összetétele}

Jelenleg két, HPV-fertőzésekben hatékony vakcina van forgalomban világszerte.

\subsubsection{Cervarix \\ (GlaxoSmithKline Biologicals) [1]}

Szuszpenziós injekció

Humán papillomavírus vakcina [16-os és 18-as típus] (rekombináns, adjuvánssal adszorbeált)

A Cervarix egy adjuvált, nem fertőző, rekombináns vakcina, amelyet az onkogén HPV-16 és HPV-18 típusok jellemző Ll kapszidproteinjeiből álló, nagymértékben tisztított vírusszerû részecskékből (VLP) állítanak elő. Mivel a VLP-k nem tartalmaznak virális DNS-t, nem képesek megfertőzni a sejteket, szaporodni vagy betegséget okozni.

Egy adag (0,5 ml) tartalma az alkalmazási előírás szerint:

- Humán papillomavírus ${ }^{1}$ 16-os típus Ll protein²,3,4 20 mikrogramm

- Humán papillomavírus ${ }^{1}$ 18-as típus Ll protein²,3,4 20 mikrogramm

Segédanyagok:

- nátrium-klorid $(\mathrm{NaCl})$,

- nátrium-dihidrogén-foszfát-dihidrát $(\mathrm{NaH} 2 \mathrm{PO} 4.2$ $\mathrm{H} 2 \mathrm{O})$,

- injekcióhoz való víz.

1 Humán papillomavírus $=\mathrm{HPV}$

2 az AS04 adjuváns tartalmaz: 3-O-dezacil- $4^{\prime}$-monofoszforil lipid A (MPL) ${ }^{3}$ 50 mikrogramm

3 hidratált alumínium-hidroxidhoz $\left(\mathrm{Al}(\mathrm{OH})_{3}\right)$ kötött 0,5 milligramm $\mathrm{Al}^{3+}$ öszszesen

4 Ll fehérje, nem fertőző vírusszerü részecske (VLP) formájában, amelyeket rekombináns DNS-technológiával állítanak elő egy Baculovírus expressziós rendszer alkalmazásával, amely Trichoplusia ni-ból származó Hi-5 Rix4446 sejteket használ fel.

\subsubsection{Silgard \\ (GARDASIL; Merck Sharp \& Dohme) [1]}

Szuszpenziós injekció

Humán papillomavírus vakcina [6-os, 11-es, 16-os, 18-as típus] (Rekombináns, adszorbeált)

A Silgard adjuvánssal adszorbeált, nem fertőző, rekombináns, kvadrivalens vakcina, amely a 6-os, 11-es, 16-os és 18-as HPV-típusok Ll-es fó kapszidfehérjéjének nagy tisztaságú vírusszerű részecskéiből (VLP-k) készül. A VLP-k nem tartalmaznak vírus-DNS-t, így nem képesek a sejteket megfertőzni, reprodukálódni, illetve betegséget okozni.

Egy adag $(0,5 \mathrm{ml})$ tartalma az alkalmazási előírás szerint:

- 6-os típusú humán papillomavírus ${ }^{1} \mathrm{Ll}$ fehérjéje $\mathrm{f}^{5,6}$ 20 mikrogramm

- 11-es típusú humán papillomavírus ${ }^{1}$ Ll fehérjéje $e^{5,6}$ 40 mikrogramm

- 16-os típusú humán papillomavírus ${ }^{1}$ Ll fehérjéje $\mathrm{f}^{5,6}$ 40 mikrogramm

- 18-as típusú humán papillomavírus ${ }^{1}$ Ll fehérjéje $\mathrm{e}^{5,6}$ 20 mikrogramm

Segédanyagok:

- nátrium-klorid,

- L-hisztidin,

- poliszorbát 80 ,

- nátrium-tetraborát,

- injekcióhoz való víz.

\section{Felhasznált irodalom}

[1] Cervarix alkalmazási elóírás: http://ec.europa.eu/health/ documents/community-register/html/alfregister.htm

[2] Silgard alkalmazási előírás: http://ec.europa.eu/health/ documents/community-register/html/alfregister.htm

5 Saccharomyces cerevisiae élesztőgomba CANADE 3C-5 törzse (1895 törzs) által termelt Ll fehérje, vírusszerü részecskék formájában, rekombináns DNS-technológiával előállítva.

6 Amorf alumínium-hidroxi-foszfát-szulfát adjuvánsra (225 mikrogramm $\mathrm{Al})$ adszorbeálva. 


\subsection{A HPV-vakcinák protektív hatásának mechanizmusa}

A humán papillomavírusok (HPV) DNS-vírusok, faj- és szövetspecifikusak, több mint 180 fajtáját klónozták már különböző klinikai laesiókból. A vírust a DNS-szekvencia alapján tipizálják, ezért genotípusoknak nevezzük. Ezek a vírusok hám- és epithelsejteket fertőznek. Két nagy csoportjuk különíthető el, az egyik alacsony rizikójú benignus hám- és mucosaelváltozást okoz, a másik csoport a magas rizikójú csoport, amelyek a hám és epithel malignus elváltozásaiért tehetők felelőssé. A HPV kizárólagosan intraepithelialis patogén és a vírus replikációja idő- és differenciációfüggő́. A bazális, nem differenciálódó hámsejteket támadja meg a vírus, amíg a sejt osztódik, addig a vírusfehérje kifejeződése erős kontroll alatt áll. Amint a sejt osztódása leáll és differenciálódni kezd, a vírus génaktivációja elszabadul, a virális proteinek magas expressziója és a víruspartikulum kialakulása a differenciálódó hámsejtekben bekövetkezik. Több ezer enkapszulált vírusgenom alakul ki, majd ezek a fertőző víruspartikulumok elhagyják a sejteket. A vírus genomja kisméretû, $8 \mathrm{~kb}$, ami nyolc gént tartalmaz, ebból hat strukturális korai $($ early $=\mathrm{E})$ fehérjéket kódol (E1, E2, E4, E5, E6 és E7), kettő pedig úgynevezett késői (late $=\mathrm{L}, \mathrm{L} 1$ és L2) fehérjét. Infekciót követóen a vírus sokáig latens maradhat. Bár a kialakuló elváltozások visszaszorításában immunológiai reakciók részt vesznek, a vírus teljes eliminálása nem történik meg, a vírus genomja tünetmentes hámban is kimutatható. Feltehetó, hogy a latens fertőzést lokális, sejt mediálta immunitás tartja kontroll alatt, elsősorban a sejt mediálta immunitást gátló immunszuppresszió következtében gyakoriak a tünetek fellángolásai (például: transzplantált betegek, HIV-fertőzöttek és autoimmun betegségben szenvedők). Regrediált anogenitalis víruspapilloma szövettanára CD4+ Th 1 típusú sejtek infiltrációja jellemző. A bazális keratinocytát megfertôzött vírus a hámsejt innate immunreakcióit visszaszorítja, ezért tud latens módon a sejten belül hosszasan túlélni, az effektív sejtes immunválasz ugyanakkor visszaszorítja a vírus szaporodását a differenciált keratinocytákban.

A mechanizmus, amelyen keresztül a HPV-vakcinák kifejtik védőhatásukat a HPV-fertőzés és a HPV okozta megbetegedésekkel szemben, még nem teljesen tisztázott, állatkísérletek alapján valószínúsíthetô, hogy mind a humorális, mind pedig a sejt mediálta immunválasz szerepet játszik a hatás kialakulásában. A vírus bazális hámsejtekbe jutása sérült hám esetén történik. Vélhetőleg az elsődleges hatásmechanizmus azon alapul, hogy a környező kapillárisokból neutralizáló antiHPV-IgG antitestek jutnak az epithelialis mucosa bazális sejtjeihez (a HPV-infekció kizárólagos célsejtjeihez), elég nagy koncentrációban ahhoz, hogy megkössék a víruspartikulumokat. A védelemben szerepet játszhat a hámsérülést követően a szérum-IgG exudációja a genitalis mucosalis felszínre, gyulladásos válaszreakciót indukálva, amely elősegíti az immunsejtek gyulladás helyére történő migrációját. A szérum-IgA és a genitalis mucosa által termelt szekretoros neutralizáló IgA transsudatiója vélhetőleg szintén szerepet játszik a mucosalis immunitásban.

A kiváltott antitestszint azonban a szervezet válaszreakciójának csupán egyik paramétere, az antitestek jelenléte vagy hiánya önmagában még nem jelenti azt, hogy az illetô védett vagy sem. Például bizonyos gyermekkori védőoltások (kanyaró, rubeola) által indukált antitestek szintje az idôvel csökken, azonban revakcináció vagy infekció másodlagos immunválaszt okoz antitesttermeléssel - ennek magyarázata az immunmemória.

A forgalomban lévő HPV-vakcinák klinikai vizsgálataiban különböző antitestmérési módszereket alkalmaztak (bivalens vakcina: teljes IgG-meghatározás, amely az összes termelődött antitest szintjét határozza meg; kvadrivalens vakcina: cLIA, amely csak egyetlen epitop ellen termelődött antitestek szintjét méri), így az eredmények sem összehasonlíthatóak. Mindkét esetben teljes IgG-meghatározást végezve például a HPV-18 elleni szeropozitivitás két év után is hasonló a két vakcina esetében.

A HPV-vakcinák esetében a védőhatással összefüggő minimális antitestszintet még nem határoztak meg, azonban az immunmemória megléte mindkét vakcina esetében bizonyított, aminek alapján a hosszú távú hatékonyság mindkét esetben feltételezhető.

Protektív immunválasz kialakítása általában igényli valamilyen adjuválószer együttes alkalmazását, enélkül a vakcina antigénjei nem elég immunogének, nem váltanak ki megfelelő specifikus aktív immunválaszt. A klaszszikusan alkalmazott, betegséget megelózni célzó, preventív vakcinák adjuvánsként az alumínium különböző formáit használják. Bár az alumínium-hidroxid majd' száz éve használatos a vakcinációban mint adjuváns, az általa okozott immunstimuláció pontos hatása még ma sem tisztázott teljes mértékben. Az alumínium a hozzá kötött antigént elnyújtva, lassan bocsátja ki, „depot” hatást fejt ki, ez is hozzájárul a sikeres aktív immunválasz kialakításához.

A vakcináció hatása az adjuváns mellett függ az alkalmazás módjától, az antigén dózisától, minőségétől, tisztaságától, az oltott személy korától, feltehetôen az oltott személy részben genetikusan, részben az aktuális környezeti hatások által meghatározott immunstátusától. A vakcinák humorális immunválaszt indukálnak, a kialakuló B-sejt-aktiváció mellett T-sejt-aktiváció is bekövetkezik.

Az utóbbi idóben megjelent vizsgálatok alapján úgy túnik, hogy az alumínium nem specifikus immunaktiváló hatása az intracelluláris természetes immunválasz aktiválásán keresztül érvényesül. Az inflammaszómaaktiválódást a makrofágok által termelt IL-1-béta- és IL-18termelés segíti. 
Irodalmi adatok alapján feltételezhető, hogy a vakcináció során kialakuló mellékhatások egy részéért az adjuváns nem specifikus immunaktivációt kiváltó hatása lehet felelős, ezért megfontolandó minél kevesebb adjuváns hatással minél szélesebb specifikus immunstimuláció kialakítása. Ebből a szempontból előnyös lehet a szélesebb antigénspektrumot lefedő, multivalens vakcinák alkalmazása, HPV esetében a kvadrivalens vakcináé.

\section{Felhasznált irodalom}

[1] Gravitt, P. E.: The known unknowns of HPV natural history. J. Clin. Invest., 2011, 121, 4593-4599.

[2] Stanley, M. A.: Epithelial cell responses to infection with human papillomavirus. Clin. Microbiol. Rev., 2012, 25, 215-222.

[3] Tomljenovic, L., Shaw, C. A.: Mechanisms of aluminum adjuvant toxicity and autoimmunity in pediatric populations. Lupus, 2012, 21, 223-230.

[4] Eisenbarth, S. C., Colegio, O. R., O'Connor, W., et al.: Crucial role for the Nalp3 inflammasome in the immunostimulatory properties of aluminium adjuvants. Nature, 2008, 453, $1122-$ 1126.

[5] Aimanianda, V., Haensler, J., Lacroix-Desmazes, S., et al.: Novel cellular and molecular mechanisms of induction of immune responses by aluminum adjuvants. Trends Pharmacol. Sci., 2009, 30, 287-295.
[6] Tomljenovic, L., Shaw, C. A.: Aluminum vaccine adjuvants: are they safe? Curr. Med. Chem., 2011, 18, 2630-2637.

[7] Einstein, M. H., Baron, M., Levin, M. J., Chatterjee, A., Fox, B., Scholar, S., Rosen, J., Chakbtoura, N., Meric, D., Dessy, F. J., Datta, S. K., Descamps, D., Dubin, G.; HPV-010 Study Group: Comparative immunogenicity and safety of human papillomavirus $(\mathrm{HPV})-16 / 18$ vaccine and $\mathrm{HPV}-6 / 11 / 16 / 18$ vaccine: follow-up from months $12-24$ in a Phase III randomized study of healthy women aged 18-45 years. Human. Vaccines., 2011, 7, $1343-1358$.

[8] Frazer, I.: Correlating immunity with protection for HPV infection. Int. J. Infect. Dis., 2007, 11 (Suppl 2), S10-6.

[9] Hernandez-Montes, J., Rocha-Zavaleta, L., Monroy-Garcia, A., et al.: Peripheral blood lymphocytes from low-grade squamous intraepithelial lesions patients recognize vaccine antigens in the presence of activated dendritic cells, and produced high levels of CD8 + IFNgamma + T cells and low levels of IL- 2 when induced to proliferate. Infect. Agent. Cancer, 2012, 29, 12.

[10] Human Papillomavirus (HPV) Vaccine Background Paper, September 2008. WHO http://www.who.int/immunization/ documents/HPVBGpaper_final_03_04_2009.pdf

[11] Nelson, W. E.: A gyermekgyógyászat tankönyve: 1015. Melania Kiadói Kft., Budapest, 1997.

[12] Brown, D. R., et al.: The humoral response to Gardasil over four years as defined by total $\operatorname{IgG}$ and competitive luminex immunoassay. Human Vaccines, 2011, 7, 230-238.

[13] Silgard alkalmazási elóírás: http://ec.europa.eu/health/ documents/community-register/html/alfregister.htm

[14] Cervarix alkalmazási elő́rás: http://ec.europa.eu/health/ documents/community-register/html/alfregister.htm 


\subsection{A HPV-vakcinák betegségmegelőző hatása klinikai vizsgálatokban}

\subsubsection{A bivalens vakcina betegségmegelózó hatása (alkalmazási eloírás) [1]}

A bivalens vakcina (Cervarix) a HPV 16, 18 típusai ellen kifejlesztett védőoltás, az EMA (European Medicines Agency - Európai Gyógyszerügyi Hatóság) a következó indikációkban törzskönyvezte:

- Kilencéves kortól adva egyes onkogén HPV-típusok által okozott perzisztáló fertôzés, premalignus cervicalis laesiók és a cervixcarcinoma prevenciójára szolgál.

Tekintettel arra, hogy a méhnyakrák kialakulásához hosszú idő szükséges, a megelőzésére létrehozott vakcinák hatékonysága leginkább a rákmegelőző állapotok (CIN 2/3 [cervicalis intraepithelialis neoplasia] és az in situ adenocarcinoma [AIS]) elófordulásának csökkenésével bizonyítható. Az előbb említett betegségvégpontokon kívül a vakcinációnak a perzisztáló fertőzésekre, illetve az antitesttermelésre kifejtett válaszát is vizsgálták. Az ilyen, virológiai vagy immunológiai pótmarkervégpontú tanulmányokból származó eredmények azonban klinikai jelentőségük, hasznosságuk szerint nem tekinthetők olyan erejünek a hatékonyság megítélésében, mint a betegségvégpontú vizsgálatok.

A Cervarix vakcinával több randomizált, placebokontrollált, klinikai vizsgálatot végeztek, összesen több mint 19700 nő bevonásával, amelyekben a „három vakcina hat hónap alatti" séma hatékonyságát és biztonságosságát vizsgálták.

Ezek közül a legjelentősebb egy nemzetközi, fázis III, randomizált, kettős vak, placebokontrollált vizsgálat (008 jelzésủ vagy PATRICIA vizsgálat).

A vizsgálatba olyan nem terhes, 15 és 25 év közötti fiatal nőket vontak be, akiknek életük során maximum hat szexuális partnerük volt. A bevonáskor a HPV-pozitivitás nem volt kizáró kritérium. Az elsődleges hatékonysági végpontot a HPV-16 és/vagy HPV-18 (HPV 16/18) függő CIN 2+ képezte.

$\mathrm{Az}$ elsődleges hatásossági elemzést a protokoll szerint kezelt kohorszban (According to Protocol avagy ATP-kohorsz) végezték el. Ebben a csoportban a vakcina mindhárom adagja beadásra került, az elemzésben vizsgált HPV-típusokra nézve DNS-negatívak, valamint szeronegatívak voltak a 0 . hónapban és DNS-negatívak maradtak a 6. hónapban.

A vakcina HPV 16/18-cal összefüggő nagyfokú cervicalis laesiók különböző kohorszban megfigyelt hatásosságát a vizsgálat zárásakor az 1 . és 2 . táblázat mutatja. Az átlagos utánkövetési idő 40 hónap volt.

A Teljes Beoltott Kohorsz (TVC, Total Vaccinated Cohors) minden résztvevőt magában foglalt, aki legalább egyvakcinányi dózisban részesült, függetlenül a kielemzése a HPV-naiv ATP-populációban

\begin{tabular}{|c|c|c|c|}
\hline & $\begin{array}{l}\text { Cervarix } \\
\mathrm{n}=7338\end{array}$ & $\begin{array}{l}\text { Placebo } \\
\mathrm{n}=7305\end{array}$ & \multirow{2}{*}{$\begin{array}{c}\text { Százalékban } \\
\text { mért } \\
\text { hatásosság } \\
(95 \% \text {-os CI) }\end{array}$} \\
\hline & Esetek száma & Esetek száma & \\
\hline $\begin{array}{l}\text { HPV 16/18-cal } \\
\text { összefü̈ggö CIN 2+ }\end{array}$ & 5 & 97 & $\begin{array}{c}94,9 \% \\
(87,7 ; 98,4)\end{array}$ \\
\hline $\begin{array}{l}\text { HPV 16/18-cal } \\
\text { összefü̈ggö CIN 3+ }\end{array}$ & 2 & 24 & $\begin{array}{c}91,7 \% \\
(66,6 ; 99,1)\end{array}$ \\
\hline
\end{tabular}

2. táblázat

A Cervarix nagyfokú cervicalis laesiók elleni hatásosságának elemzése a TVC-populációban, amelybe a vizsgálat kezdetekor fennálló $H P V$-státustól függetlenül vonták be a nôi résztvevőket

\begin{tabular}{l|c|c|c}
\hline & $\begin{array}{c}\text { Cervarix } \\
\mathrm{n}=8694\end{array}$ & $\begin{array}{c}\text { Placebo } \\
\mathrm{n}=8708\end{array}$ & $\begin{array}{c}\text { Százalékban } \\
\text { mért } \\
\text { hatásosság } \\
(95 \% \text {-os CI })\end{array}$ \\
\cline { 2 - 3 } & Esetek száma & Esetek száma & $\begin{array}{c}60,7 \% \\
(49,6 ; 69,5)\end{array}$ \\
\hline $\begin{array}{l}\text { HPV 16/18-cal } \\
\text { összefüggö CIN 2+ }\end{array}$ & 90 & 228 & $\begin{array}{c}45,7 \% \\
\text { HPV 16/18-cal } \\
\text { összefüggö CIN 3+ }\end{array}$ \\
$\begin{array}{l}\text { HPV 16/18-cal } \\
\text { összefüggö AIS [2] }\end{array}$ & 51 & 94 & $\begin{array}{c}22,9 ; 62,2) \\
76,9 \% \\
(16,0 ; 95,8)\end{array}$ \\
\hline
\end{tabular}

indulási idôpontban megállapított HPV-DNS státusától, citológiai eredményétól és szerológiai státusától. Ez a populáció a vizsgálat kezdetekor fennálló HPV-fertőzés vagy megbetegedések tekintetében az általános nôi populációhoz hasonló. Az esetszámlálás az első dózis beadását követő első napon megkezdődött.

A vizsgálat során értékelték a Cervarix keresztvédelemben való hatásosságát a hisztopatológiai és virológiai végpontokban (perzisztáló fertőzés) is 12 , a vakcina által nem tartalmazott onkogén HPV-típussal szemben. A vizsgálat statisztikai ereje nem tette lehetővé az egyes HPV-típusok által okozott betegségek elleni hatásosság értékelését. A primer végponttal kapcsolatos analízisben zavaró tényezót jelentettek a CIN 2+ laesiókban bekövetkező többszörös egyidejű fertőzések. A HPV-31, -33 és -45 esetében konzisztens keresztvédelem mutatkozott a hat hónapos perzisztáló fertózés és a CIN 2+ végpontokban, az összes vizsgálati kohorszban.

A 26 évnél idősebb nők esetén a Cervarix hatásosságát egy olyan kettős vak, randomizált, fázis III klinikai vizsgálatban értékelték, amelyben összesen 5777, 26 évesnél idősebb nő vett részt. Elsődleges végpontként a hat hónapos, perzisztens HPV 16/18 fertőzés (pótmarker) szerepelt. 48 hónapos utánkövetéssel, ATP hatásossági kohorszban a fenti virológia végpont elleni hatásosság 82,19\% $(97,7 \%$ CI: 53,8; 95,1), míg TVCben $47 \%$ (97,7\% CI: 25,$4 ; 62,7)$.

A vakcinák vizsgálata során fontos, hogy milyen hatékonysággal indukálnak szerokonverziót, ezért egy másik 
klinikai vizsgálatban 9 és 55 év közötti, összesen 5465 lányban/nőben megvizsgálták a bivalens vakcina által indukált immunogenitást. A vakcina harmadik adagja után egy hónappal a kiinduláskor szeronegatív alanyok több mint 99\%-ánál figyeltek meg szerokonverziót a HPV-16 és a HPV-18 tekintetében. A vakcina által indukált IgG geometriai átlagtitere (GMT) jelentősen meghaladta az azon nókben mért ellenanyagszintet, akiknek korábban HPV-fertőzésük volt, de az megszűnt (természetes fertőzés utáni állapot).

Egy csoportban folytatták az ellenanyagszintek monitorizálását; 8,9 éves átlagos követési idővel ezen alanyok 100\%-a HPV-16- és HPV-18-szeropozitív maradt.

A HPV-vakcinák esetében a védőhatással összefüggó minimális antitestszintet még nem határoztak meg.

$\mathrm{Az}$ anamnesztikus immunválaszt (immunmemóriát) egy 65 nőn végzett egyadagnyi Cervarix próbaoltással igazolták. A korábban teljes oltási sorozatot kapott nők átlagban 6,8 évvel a legelső oltás után egy próbaoltást kaptak. A próbaoltás utáni egy hónapos GMTértékek meghaladták azokat, amelyeket egy hónappal a primer, háromoltásos sorozatot követően mértek.

A HPV-vakcinák elsődleges célcsoportja a praeadolescens korban levő lányok, ezért külön megvizsgálták a vakcinálást követő immunogenitási adatokat ebben a csoportban, s ez arra enged következtetni, hogy a Cervarix hatékony a 9-14 éves korcsoportban is.

A klinikai vizsgálatok egyértelmúen azt mutatják, hogy a bivalens HPV-vakcina hatékony védelmet nyújt a 16-os és a 18-as HPV-törzsek okozta méhnyaki premalignus intraepithelialis laesiók, a méhnyakrák és a méhnyak in situ adenocarcinomája ellen. A vakcina által nem tartalmazott bizonyos HPV-típusok ellen keresztvédelem is kialakul. A védelem azoknál a nőknél a legnagyobb, akik még nem estek át korábban onkogén HPV-infekción.

\subsubsection{A kvadrivalens vakcina betegségmegelözö hatása (alkalmazási elöirás) [3]}

A kvadrivalens vakcina (Silgard) a HPV 6, 11, 16, 18 típusai ellen kifejlesztett védőoltás, az EMA a következő indikációkban törzskönyvezte:

\section{- Kilencéves kortól}

- a HPV bizonyos onkogén típusai által okozott premalignus genitalis laesiók (cervicalis, vulvalis és vaginalis), méhnyakrák, valamint

- specifikus HPV-típusok által okozott genitalis szemölcsök (condyloma acuminatum) megelözésére szolgál.

Tekintettel arra, hogy a méhnyakrák kialakulásához hoszszú idő szükséges, a megelőzésére kifejlesztett vakcinák hatékonysága a rákmegelőző állapotok (CIN 2/3 és az in situ adenocarcinoma [AIS]) előfordulásának csökkenésével bizonyítható.
A Silgard hatékonyságát számos nagy klinikai vizsgálatban kutatták, több mint 20500 nő bevonásával, ezek közül a legjelentősebb két nemzetközi, fázis III, randomizált, kettős vak, placebokontrollált vizsgálat (FUTURE I és FUTURE II).

A vizsgálatokba olyan nem terhes, 16 és 26 év közötti fiatal nőket vontak be, akiknek életük során maximum négy szexuális partnerük volt. A bevonáskor a HPVpozitivitás nem volt kizáró kritérium.

Egy korai fázis II vizsgálat igazolta, hogy a kvadrivalens vakcina 90\%-ban hatékony a perzisztáló HPV-6, -11,-16 és -18 fertőzés megelőzésében. A beoltott nők 100\%-ánál figyeltek meg szerokonverziót az oltás harmadik dózisát követően.

A FUTURE I klinikai vizsgálat megállapította, hogy a protokoll szerint kezelt HPV-naiv populációban (PPEpopuláció) a vakcina hatékonysága $100 \%$-os volt a HPV$6,-11,-16,-18$ okozta cervicalis, vulvaris, vaginalis és perianalis premalignus intraepithelialis laesiók megelözésében. Ugyancsak 100\%-os hatékonyságot mutatott a HPV-6, -11 okozta genitalis condylomák kialakulásával szemben.

A FUTURE II vizsgálat megállapította, hogy a protokoll szerint kezelt HPV-naiv populációban (PPE) a kvadrivalens vakcina $100 \%$-os hatékonyságot mutatott a HPV 16/18 asszociált CIN 2/3, AIS és méhnyakrák megelőzésében.

Táblázatok mutatják be a négy klinikai vizsgálat eredményeit, összegezve a kvadrivalens vakcina hatékonyságát a cervicalis premalignus laesiókkal szemben.

Az átlagos utánkövetési idő 3,6 év volt.

A 3. táblázatban a PPE-populációra vonatkozó eredmények láthatók. Ebben a csoportban a vakcina mindhárom adagjának beadása megtörtént, nem voltjelentôs eltérés a vizsgálati protokolltól, és a bevont nők nem fertőződtek az adott HPV-típusokkal (HPV-6, -11, -16 vagy -18) sem az első dózis beadását megelőzően, sem a harmadik dózis beadását követően egy hónapon át.

A kezelési szándék szerinti (intention to treat - ITT), módosított populáció (4. táblázat) olyan nókből állt, akik a vizsgálat első napján fennálló HPV-státusuktól függetlenül legalább egy adag vakcinát vagy placebót kaptak. Ez a populáció a vizsgálat kezdetekor fennálló HPV-fertőzés vagy megbetegedések szempontjából az általános női populációhoz hasonló.

A FUTURE vizsgálatokban értékelték a Silgard hatékonyságát a vulva és a vagina rákmegelőző állapotaival szemben is. A vizsgálatok PPE-populációjában a Silgard hatékonysága a HPV-6, -11, -16 és -18 okozta VIN 2/3-mal és VaIN 2/3-mal szemben egyenként 100\%-os volt. (VIN: vulvaris intraepithelialis neoplasia; VaIN: vaginalis intraepithelialis neoplasia.) A kezelési szándék szerinti (ITT) módosított populációban hatékonysága a HPV-6, -11, -16, -18 okozta VIN 2/3-mal szemben $73,3 \%$, a HPV-6, -11, -16, - 18 okozta VaIN $2 / 3$-mal szemben $85,7 \%$ volt. 
A Silgard nagyfokú cervicalis laesiók elleni hatásosságának elemzése a HPV-naiv PPE-populációban

\begin{tabular}{|c|c|c|c|}
\hline & $\begin{array}{c}\text { Silgard } \\
\mathrm{n}=8493\end{array}$ & $\begin{array}{l}\text { Placebo } \\
\mathrm{n}=8464\end{array}$ & \multirow{2}{*}{$\begin{array}{c}\text { Százalékban } \\
\text { mért } \\
\text { hatásosság } \\
(95 \% \text {-os CI) }\end{array}$} \\
\hline & Esetek száma & Esetek száma & \\
\hline $\begin{array}{l}\text { HPV 16/18-cal } \\
\text { összefüggö CIN } 2 / 3 \\
\text { vagy AIS }\end{array}$ & 2 & 112 & $\begin{array}{c}98,2 \\
(93,5 ; 99,8)\end{array}$ \\
\hline $\begin{array}{l}H P V \text { 16/18-cal } \\
\text { összefüggö CIN } 3\end{array}$ & 2 & 64 & $\begin{array}{c}96,9 \\
(88,4 ; 99,6)\end{array}$ \\
\hline $\begin{array}{l}H P V \text { 16/18-cal } \\
\text { összefüggo" AIS }\end{array}$ & 0 & 7 & $\begin{array}{c}100 \\
(30,6 ; 100,0)\end{array}$ \\
\hline
\end{tabular}

4. táblázat

A Silgard nagyfokú cervicalis laesiók elleni hatásosságánah elemzése az ITT-populációban, amelybe a vizsgálat kezdeteko fennálló HPV-státustól függetlenül vonták be a női résztvevőket

\begin{tabular}{l|c|c|c}
\hline & $\begin{array}{c}\text { Silgard } \\
\mathrm{n}=9836\end{array}$ & $\begin{array}{c}\text { Placebo } \\
\mathrm{n}=9904\end{array}$ & $\begin{array}{c}\text { Százalékban } \\
\text { mért } \\
\text { hatásosság } \\
(95 \% \text {-os CI })\end{array}$ \\
\cline { 2 - 3 } & Esetek száma & Esetek száma & $\begin{array}{c}51,8 \\
(41,1 ; 60,7)\end{array}$ \\
\hline $\begin{array}{l}\text { HPV 16/18-cal } \\
\text { osszefüggö CIN 2/3 } \\
\text { vagy AIS }\end{array}$ & 146 & 303 & $\begin{array}{c}46,0 \\
\text { HPV 16/18-cal } \\
\text { osszefüggö CIN 3 }\end{array}$ \\
$\begin{array}{l}\text { HPV 16/18-cal } \\
\text { osszefüggö AIS }\end{array}$ & 103 & 191 & $\begin{array}{c}61,0 ; 57,9) \\
60,0 \\
(<0 ; 87,3)\end{array}$ \\
\hline
\end{tabular}

A kvadrivalens vakcina nagy előnye, hogy védelmet nyújt az anogenitalis szemölcsök (condyloma acuminatum) kialakulása ellen is. A HPV-naiv PPE-csoportban a vakcina 99\%-os hatékonysággal előzte meg a HPV 6/11 asszociált anogenitalis szemölcsök megjelenését.

A vizsgálatokban értékelték a Silgard keresztvédelemben való hatékonyságát. Ennek során szignifikáns, 23\%-os (95\% CI: 5,1-37,7) hatékonyság igazolódott a vakcina által nem tartalmazott további $10 \mathrm{HPV}$-típus által okozott CIN 2/3-mal, vagy AIS-sel szemben (ideértve a laboratóriumi vizsgálattal azonosított, vakcina által nem tartalmazott HPV-31, $-33,-35,-39,-45,-51$, $-52,-56,-58$ és -59 típusokat). A vizsgálatokat statisztikai szempontból nem az egyes HPV-típusok által okozott megbetegedések elleni hatásosság megállapítására tervezték.

A Silgard esetében a vakcina által kiváltott immunogenitást 9-26 éves lányoknál és nőknél, valamint 9-26 éves fiúknál és férfiaknál, és 24-45 éves nőknél értékelték. A 16-26 éves nőkön végzett klinikai vizsgálatok során a Silgarddal oltott személyek 99,8\%-a vált antiHPV-6-, 99,8\%-a anti-HPV-11-, 99,8\%-a anti-HPV16- és 99,5\%-a anti-HPV-18-szeropozitívvá egy hónappal a harmadik dózis beadását követően. A 24-45 éves nőkön végzett klinikai vizsgálatok során a Silgarddal oltott személyek 98,4\%-a vált anti-HPV-6-, 98,1\%-a anti-HPV-11-, 98,8\%-a anti-HPV-16- és 97,4\%-a anti-
HPV-18-szeropozitívvá egy hónappal a harmadik dózis beadását követően. A 16-26 éves férfiakon végzett klinikai vizsgálatok során a Silgarddal oltott személyek 98,9\%-a vált anti-HPV-6-, 99,2\%-a anti-HPV-11-, 98,8\%-a anti-HPV-16- és 97,4\%-a anti-HPV-18-szeropozitívvá egy hónappal a harmadik dózis beadását követően. A várakozásoknak megfelelően, a 24-45 éves nőknél megfigyelt antitesttiter alacsonyabb volt a 16-26 éves nőknél megfigyeltnél. A HPV-vakcinák elsődleges célcsoportja a preadoleszcens korban levő lányok, ezért külön megvizsgálták a vakcinálást követő immunogenitási adatokat ebben a csoportban; ezek szerint gyermekekben (10-15 év között) a vakcina magas hatékonysággal indukált szerokonverziót.

A védelem tartósságának igazolásához utánkövették a vakcinálást követő szerológiai választ, amely a vakcinációt követően 8,5 éven keresztül detektálható maradt.

A HPV-vakcinák esetében a védőhatással összefüggő minimális antitestszintet még nem határoztak meg.

$\mathrm{Az}$ anamnesztikus immunválaszt (immunmemóriát) Silgard esetén is igazolták. Az előzetesen teljes oltási sort kapott nők, az első vakcinát követő ötödik évben Silgard próbaoltást kaptak, amelyre gyors és erős anamnesztikus választ mutattak. (A próbaoltás utáni GMT meghaladta az eredeti oltási sor harmadik dózisa után egy hónappal mért anti-HPV geometrikus átlagtitert.)

\section{Hatásosság 16-26 éves férfiaknál}

A hatásosságot HPV-6, -11, -16, -18 okozta külső genitalis szemölcsök, $1 / 2 / 3$ fokozatú penis/perinealis/ perianalis intraepithelialis neoplasia (PIN) és perzisztens fertőzés ellen értékelték. A Silgard hatásosságát 16-26 éves férfiaknál egy placebokontrollos, kettős vak, randomizált fázis III klinikai vizsgálatban értékelték, összesen 4055 férfi részvételével, akiket előzetes humán papillomavírus-szû́rés nélkül vontak be a vizsgálatba és oltottak be. A követés medián időtartama 2,9 év volt. A HIV-fertőzés kizárási kritérium volt.

A vakcina $H P V$-típusok (HPV-6, -11, -16 vagy -18) hatásosságának elsődleges elemzéseit a per protokoll (PPE) populációban végezték el, vagyis mind a három oltás beadása megtörtént a vizsgálatba való bevonástól számított egy éven belül, nincs jelentős eltérés a vizsgálati protokolltól és a beteg nincs kitéve az adott HPVtípus(ok)nak az első dózis beadását megelőzően és a harmadik dózis beadását követően egy hónapig. A klinikai vizsgálatok során az analis intraepithelialis neoplasia (AIN) 2/3 fokozatát (közepes/nagyfokú dysplasia) használták az analis carcinoma helyettesítő markereként. A követés medián időtartama 2,4 év volt. A vizsgálat eredményeit az 5. táblázat foglalja össze.

A kezelési szándék szerinti (ITT) módosított populáció olyan férfiakból állt, akik a vizsgálat első napján fennálló HPV-státusuktól függetlenül legalább egy adag vakcinát kaptak, és az esetek összeszámolása az első na- 
5. táblázat | A Silgard külsögenitalis laesiók elleni hatásossága a 16-26 éves férfiak PPE-populációjában

\begin{tabular}{|c|c|c|c|c|c|}
\hline \multirow[t]{2}{*}{ Végpont } & \multicolumn{2}{|c|}{ Silgard } & \multicolumn{2}{|c|}{ Placebo } & \multirow{2}{*}{$\begin{array}{l}\text { \%-ban mért hatásosság } \\
\qquad(95 \%-\text { os } \mathrm{CI})\end{array}$} \\
\hline & $\mathrm{N}$ & Esetek száma & $\mathrm{N}$ & Esetek száma & \\
\hline \multicolumn{6}{|c|}{ HPV 6/11/16/18 okozta } \\
\hline Külső genitalis laesiók & 1394 & 3 & 1404 & 32 & $90,6(70,1,98,2)$ \\
\hline Genitalis szemölcsök & 1394 & 3 & 1404 & 28 & $89,3(65,3,97,9)$ \\
\hline 1/2/3 fokozatú PIN & 1394 & 0 & 1404 & 4 & $100,0(-52,1,100,0)$ \\
\hline
\end{tabular}

pon kezdődött. Ez a populáció a vizsgálat kezdetekor fennálló HPV-fertőzés vagy megbetegedések szempontjából az általános férfi populációhoz hasonló.

A Silgard hatásossága a HPV-6, -11, -16, -18 okozta külső genitalis szemölcsök ellen 68,1\% (95\%-os CI: 48,8, 79,3 ) volt.

A klinikai vizsgálatok egyértelmúen azt mutatják, hogy a kvadrivalens HPV-vakcina hatékony védelmet nyújt a 6-os, 11-es, 16-os, illetve a 18-as HPV típusai okozta méhnyakrák, hüvelyi és vulvaris intraepithelialis neoplasia, a méhnyak in situ adenocarcinomája (AIS), valamint a genitalis szemölcsök ellen, legnagyobb mértékben azoknál a nőknél, akik még nem estek át korábban HPV-infekción. Emellett 16-26 éves férfiak esetében is szignifikáns hatékonyságot mutat a HPV-6, -11, -16 és -18-as típusai által okozott külső genitalis laesiókkal és genitalis szemölcsökkel szemben.

A két vakcinával elvégzett fenti klinikai vizsgálatok eredményei egymással nem összehasonlíthatóak, mivel azokat különböző HPV-háttérprevalenciájú populációkban végezték, a bevont pácienek körében különböző volt a HPV 16/18 koinfekció mértéke, különbözött a vizsgálatok tervezése, valamint a vizsgálatokban nyert adatokat különbözőképpen dolgozták fel.

\section{Felhasznált irodalom}

[1] Cervarix alkalmazási elóírás: http://ec.europa.eu/health/ documents/community-register/html/alfregister.htm

[2] Lehtinen, M., Paavonen, J., Wheeler, C. M., et al.: Overall efficacy of HPV-16/18 AS04-adjuvanted vaccine against grade 3 or greater cervical intraepithelial neoplasia: 4-year end-of-study analysis of the randomised, double-blind PATRICIA trial. Lancet Oncol., 2012, 13, 89-99.

[3] Silgard alkalmazási elóírás: http://ec.europa.eu/health/ documents/community-register/html/alfregister.htm

\subsubsection{A kvadrivalens és a bivalens vakcina batályos alkalmazási elöirásának összehasonlitása}

A két forgalomban lévő vakcinával kapcsolatban nem ismert olyan direkt összehasonlító vizsgálat, amely azonos körülmények között, azonos populációban vetette volna össze a két vakcina hatékonyságát, elsődleges végpontként virológiai vagy rákmegelőző állapotot megjelölve. Az egyetlen direkt összehasonlítás a két vakcina immunogenitásának összehasonlítására szolgált, a kiváltott antitestszinteket vizsgálta vakcinánként 553 nöt randomizálva [1]. Mivel azonban a HPV-vakcinák tekintetében a védőhatással összefüggő minimális antiestszintet még nem határozták meg, ezt a vizsgálatot nem elemezzük részletesen a hatékonyság összehasonlítása céljából. Azonos körülmények között végzett vagy betegségvégpontú direkt összehasonlító vizsgálat hiányában a vakcinák összehasonlítását az alábbi szempontok mentén tehetjük meg.

\subsubsection{Betegségspektrum, terápiás javallatok $[2,3]$}

Vizsgálhatjuk a vakcinákkal megelőzhető betegségek spektrumát. Amennyiben a cél a méhnyakrák hatékony megelőzése, mind a bivalens (HPV-16, -18), mind a kvadrivalens (HPV-6, -11,-16,-18) vakcina egyformán jó hatékonysággal alkalmazható. Ha a ritkábban előforduló vulva és a hüvely rosszindulatú daganatait, valamint a méhnyakráknál nagyságrenddel gyakoribb nemi szervi szemölcsök kialakulásának a megelőzését is el akarjuk érni, erre csak a kvadrivalens vakcina alkalmazása esetén van lehetőség. A kvadrivalens és bivalens vakcinák klinikai vizsgálataiban igazolódott, különböző betegségek elleni hatékonyságot a 6. táblázat foglalja össze.

\subsubsection{Az immunogenitás vizsgálata}

A vakcinák vizsgálata során fontos, hogy milyen hatékonysággal indukálnak szerokonverziót, ezért mindkét vakcina klinikai vizsgálataiban értékelték a vakcinák által indukált immunogenitást. A részletes eredményeket az előző fejezet tárgyalja.

Az eredmények értékelésénél figyelembe kell vennünk a klinikai vizsgálatokban alkalmazott ellenanyagszintmérési módszereket. Neutralizáló antitestek ugyanis számos epitop ellen termelődnek a vakcinációt követően. Egyes ellenanyagszint-mérési módszerek (például kompetitív Luminex-alapú immunoassay [cLIA]) csak egyetlen epitop ellen termelt ellenanyagok szintjét mérik, míg más módszerek (például teljes IgG-meghatározás) az összes termelődött antitest szintjét határozzák meg. A két HPV-vakcina klinikai vizsgálataiban különböző antitestmérési módszereket alkalmaztak, így az eredmények sem összehasonlíthatóak. Mindkét esetben teljes IgG-meghatározást végezve például a HPV-18 elleni szeropozitivitás két év után is hasonló a két vakcina ese- 


\begin{tabular}{llr}
\hline & Bivalens vakcina & Kvadrivalens vakcina \\
\hline HPV-16, -18-cal összefüggö CIN 3 & $91,7 \%(95 \%$ CI: 66,6-99,1) & $96,9 \%(95 \%$ CI: 88,4-99,6) \\
HPV-6, -11, -16 és -18 okozta vulvarák & Nincs klinikai vizsgálati eredmény & $100 \%(95 \%$ CI: 67,2-100) \\
HPV-6, -11, -16 és - 18 okozta vaginarák & Nincs klinikai vizsgálati eredmény & $100 \%(95 \%$ CI: 55,4-100) \\
HPV-6, -11 okozta condyloma acuminatum & A vakcina nem véd a HPV 6-os és 11-es típusaival szemben & $99 \%(95 \%$ CI: 96,2-99,9) \\
\hline
\end{tabular}

tében [4]. A két vakcina immunogenitásának összehasonlítására irányuló vizsgálatban a bivalens vakcina által kiváltott ellenanyagszint magasabb volt, mint a kvadrivalens vakcina esetén, azonban ennek jelentősége nem ismert, hiszen a HPV-vakcinák esetében a védőhatással összefüggő minimális antitestszintet még nem határoztak meg. Az immunmemória megléte (revakcináció vagy a fertőzés megjelenése másodlagos immunválaszt okoz antitesttermeléssel) mindkét vakcina esetében bizonyított, aminek alapján a hosszú távú hatékonyság mindkét esetben feltételezhető.

\subsubsection{Keresztvédelem}

A keresztvédelemre vonatkozó részletes eredményeket az előző fejezet tárgyalja. A keresztvédettség alá eső HPV-típusok relatíve kis prevalenciája (a 16/18-as típusok nagy gyakoriságához képest), de fóként az ellenük mérhető, lényegesen gyengébb protektív hatás (a 16/18-as típusokra gyakorolt, közel 100\%-os hatáshoz képest) miatt a vakcinán kívüli típusokból adódó előny töredéke a 16/18-as megbetegedések megelőzéséből származó előnynek [5]. A két készítmény összes HPV-típus elleni százalékos hatékonysági eredményeinek indirekt összehasonlításakor figyelembe kell vennünk továbbá, hogy azok nem azonos HPV-prevalenciájú populációkban születtek. Az összes HPV-típus ellen nagyobb relatín százalékos hatást mutató bivalens vakcina klinikai vizsgálatait fơként alacsonyabb HPVprevalenciájú területeken végezték, míg a kvadrivalens vakcinát többnyire magas HPV-prevalenciájú országok pácienseinek bevonásával vizsgálták. A 16/18 elleni oltásokkal ki nem védhető típusokkal fennálló méhnyakrákok gyakorisága tehát nem változik az oltott és az oltatlan csoportban, ezért minél nagyobb ezek háttér-prevalenciája, annál jobban „felhígítja” a kivédhető típusok okozta méhnyakrákok csökkenésében mutatkozó abszolút vakcinahatást, amely mindkét vakcina esetében megközelítőleg azonos mértékú, azaz a megelőzhető méhnyakrákok száma 100000 vakcinált nőre vonatkoztatva közel azonos $[5,6,7,8]$. Ugyanazt a vakcinát egy nagyobb össz-HPV-prevalenciájú populációban vizsgálva kisebb relatív százalékos csökkenést fogunk tapasztalni, mert a meg nem előzhető HPVtípusok jobban felhígítják a megelőzhető fertőzésekre gyakorolt hatást. Azaz mindkét vakcina esetén biztonsággal elmondható, hogy a HPV-naiv, fiatal korosztályban az alkalmazási elóírásban szereplő 16/18-as típusok által okozott CIN 3+ elváltozások megelőzésében közel 100\%-os hatékonyságúak, és hosszú távon megőrzik preventív képességüket. A vakcinák által nem tartalmazott típusokkal szembeni védelem azonban lényegesen kisebb, típusonként nagyon eltérő, és időtartama is rövidebb, mint a 16/18-as típusokkal szembeni védettség. Az összes HPV-típussal szembeni prevenció pedig félrevezető adat lehet a klinikai vizsgálatokban nem járatos szakembereknek is, mert ezek közel 70\%-a mögött kizárólag a 16/18-as típusok által okozott megbetegedések kivédése áll, mivel a vizsgált laesiókban HPV-16- és -18-koinfekció volt kimutatható a vakcina által nem tartalmazott HPV-típusok mellett. Minél fiatalabb korcsoportot vizsgálunk (15-17, 18-20, 21-25 év), annál nagyobb ugyanis a 16/18-as típusok aránya.

\subsubsection{Nemek szerinti alkalmazhatóság [2, 3]}

A bivalens vakcina vizsgálatai csak nók körében igazolták a vakcina hatékonyságát, míg a kvadrivalens vakcina esetében az elvégzett klinikai vizsgálatokban a nők mellett a 16-26 éves férfiak esetében is szignifikáns hatékonyság igazolódott a HPV-6, -11, -16 és -18 típusok által okozott külső genitalis laesiókkal és genitalis szemölcsökkel szemben. A kvadrivalens vakcina 9-15 éves fiúkban történő alkalmazásának alapjául három, ebben a korosztályban is immunogenitást igazoló klinikai vizsgálat szolgál.

\subsubsection{Adagolás, az alkalmazás módja [2, 3]}

Mindkét HPV-vakcina kilencéves kortól indikált, felső korhatárt az alkalmazási elóírás terápiás javallatok pontja egyik vakcina esetében sem jelöl meg. A teljes oltási sorozat mindkét esetben három oltásból áll, amelyet fél év alatt kell beadni. Az adagolás ütemezésétől adott esetben el lehet térni, azonban a teljes oltási sorozatot, azaz a három oltást egy éven belül be kell adni. Az emlékeztető oltás szükségességét még egyik vakcina esetében sem állapították meg. Mindkét vakcinát intramuscularis injekció formájában kell beadni.

\section{Felhasznált irodalom}

[1] Einstein, M. H., et al.: Comparative immunogenicity and safety of human papillomavirus (HPV)-16/18 vaccine and HPV$6 / 11 / 16 / 18$ vaccine. Human Vaccines, 2011, 7 (12), 13431358 .

[2] Cervarix alkalmazási elő́rás: http://ec.europa.eu/health/ documents/community-register/html/alfregister.htm

[3] Silgard alkalmazási elóírás: http://ec.europa.eu/health/ documents/community-register/html/alfregister.htm 
[4] Brown, D. R., et al.: The humoral response to Gardasil over four years as defined by total IgG and competitive luminex immunoassay. Human Vaccines, 2011, 7 (2), 230-238.

[5] Jit, M., Chapman, R., Hughes, O., et al.: Comparing bivalent and quadrivalent human papillomavirus vaccines: economic evaluation based on transmission model. BMJ, 2011, 343, d5775.

[6] Lebtinen, M., Paavonen, J., Wheeler, C. M., et al.: Overall efficacy of HPV-16/18 AS04-adjuvanted vaccine against grade 3 or greater cervical intraepithelial neoplasia: 4-year end-of-study analysis of the randomised, double-blind PATRICIA trial. Lancet Oncol., 2012, 13, 89-99.
[7] Lehtinen, M., Paavonen, J., Wheeler, C. M., et al.: Lancet Oncol., 2012, 13, 89-99. http://download.thelancet.com/mmcs/journals/ lanonc/PIIS $1470204511702868 / \mathrm{mmcl} \cdot \mathrm{pdf} ? \mathrm{id}=\mathrm{e} 162413$ 98b8eb460:-573c09ac:13543a82358:6501328282336235. Supplement tables 1-3; supplement figures 1-3. Accessed February $3,2012$.

[8] Munoz, N., et al.: The impact of human papillomavirus (HPV) $6 / 11 / 16 / 18$ vaccine on all $\mathrm{HPV}$-associated genital diseases in young women. J. Natl. Cancer Inst., 2010, 102, 325-339. 


\subsection{A HPV-vakcinák betegségmegelőző hatása populációs szinten $[1,2]$}

A forgalomban lévő HPV-vakcinák hatásosságának öszszehasonlítása történhet a klinikai vizsgálatok, populációs ökológiai vizsgálatok és a modellezett hatástanulmányok szintjén.

A vakcináció társadalmi, a valós életben tapasztalható hatásait populációs ökológiai vizsgálatokban értékelhetjük legreálisabban.

Ausztrália volt az első ország, ahol 2007 áprilisában átfogó, államilag finanszírozott nemzeti HPV-vakcinációs programot indítottak a kvadrivalens Silgard vakcina alkalmazásával, a már régóta jelentős és sikeresen múködő nemzeti méhnyakrákszưrő program kiegészítéseként.

A program keretein belül Ausztrália Victoria Államában 2007. április 1-jétől a 12-13 éves lányok kapták meg térítésmentesen a négykomponensü Silgard vakcinát az iskolákban. A 13-17 éves lányoknak az iskolákban, a 18-26 éves nőknek főként a háziorvosnál biztosítottak térítésmentesen felzárkóztató oltási lehetőséget. A programban csak ausztráliai lakosok vehettek részt.

\subsubsection{A vakcináció hatása a mébnyak rákmegelözó állapotainak incidenciájára}

A vizsgálatban a vakcinációt követő közel hároméves periódusban (2007. április 1.-2009. december 31.) előforduló, a méhnyak rákmegelőző állapotainak (CIN 2+, AIS) gyakoriságát hasonlították össze a vakcinációt megelőző időszakban (2003. január 1.-2007. március 31.) megfigyelhető előfordulással. A citológiai eredményeket a Victorian Cervical Cytology Registryből (VCCR: Victoria állambeli méhnyak-citológiai regiszter) nyerték. A VCCR szinte valamennyi, Victoria államban végzett cervix citológiai és hisztopatológiai vizsgálat eredményét tartalmazza, átfogó képet adva ezáltal az oltóprogram kimeneteléról szinte a teljes populációra vonatkoztatva.

A vakcináció bevezetését követően három éven belül 48\%-os relatív kockázatcsökkenés volt tapasztalható a méhnyak rákmegelőző állapotainak előfordulási gyakoriságában a 18 évesnél fiatalabb korosztályban. Ugyanakkor nem mutatkozott szignifikáns csökkenés a 18 év feletti korosztályban (1. ábra). (Relatív kockázatcsökkenés: a vizsgált esemény gyakoriságában bekövetkezett százalékos csökkenés az oltott csoportban a kontrollcsoporthoz képest.)

\subsubsection{A vakcináció hatása a condyloma acuminatum incidenciájára}

A vizsgálatban a vakcinációt követő kétéves periódusban (2007. június-2009. december) értékelték a condyloma acuminatum előfordulási gyakoriságát is, összevet- ve a vakcinációt megelőző időszak (2004. január-2007. június) előfordulási gyakoriságával. Az adatgyújtéshez nyolc vizsgálóhelyet jelöltek ki, elszórtan Ausztrália területén. A centrumokat a méretük, elhelyezkedésük, valamint a számítógépes betegadat-nyilvántartó rendszerük alapján választották ki.

A vakcináció bevezetését követően két éven belül nagymértékü, 59\%-os csökkenés mutatkozott a condyloma előfordulási gyakoriságában is a 26 évesnél fiatalabb nők körében. Nem tapasztaltak csökkenést a 26 évesnél idősebb és a nem ausztrál női lakosok között, valamint a homoszexuális férfiak között sem. Emellett azonban a heteroszexuális, 26 évnél fiatalabb férfiak körében 39\%-os, következményes csökkenés volt megfigyelhető a condylomák előfordulásában, bizonyítva az átoltottság növekedésének pozitív populációs hatásait (2. ábra).

\subsection{3. Átoltottsági adatok}

Az átoltottság az iskolai programban az első dózisra vonatkoztatva $80 \%$-os, a komplett három dózisra 70\%-os lefedettséget mutatott. A 15-26 évesek körében a felzárkóztató oltási program keretében a kohorsz 58\%-a kapott legalább egy vakcina dózist a háziorvosától.

\subsubsection{Megbeszélés}

A III. fázisú, klinikai vizsgálatok mellett az ausztráliai vizsgálat a világon elsőként a valós életben, populációs szinten, népegészségügyi szempontból is igazolja a kvadrivalens HPV-vakcina hatékonyságát mind a HPV okozta malignus, mind pedig a rekurráló megbetegedések terén.

A HPV-fertőzés és a malignus betegség kialakulása között évtizedek telhetnek el, így a program hatása a rákkockázat hosszú távú csökkenésére csak később ítélhető meg pontosan. Azonban a condyloma acuminatum előfordulási gyakoriságának csökkenése jó indikátora a vakcináció hatékonyságának, mivel a condyloma a malignus megbetegedéseknél sokkalta gyakoribb, valamint a fertőzéstől számítva korábban manifesztálódik.

A vizsgálat azon eredménye, miszerint a méhnyak rákmegelőző állapotainak incidenciája elsőként a legfiatalabb beoltott kohorszban következett be, a felzárkóztató oltásokban részesülő, vélhetőleg szexuálisan már aktív kohorszokat megelőzve, megerősíti a szexuálisan még nem aktív korosztály oltásának fontosságát.

Az ausztráliai ökológiai vizsgálat eredményei a továbbiakban felvetik a szűrőprogramok átalakításának szükségességét, adaptálva egy posztvakcinációs környezethez, valamint szürési algoritmusok kidolgozását teszik szükségessé az átoltott populációkban.

Mivel az ausztráliai vizsgálat eredményei bizonyították a világon elsőként a $\mathrm{HPV}$-vakcináció populációs hatásait, ezért ebben a fejezetben csak ezzel foglalkoztunk. 

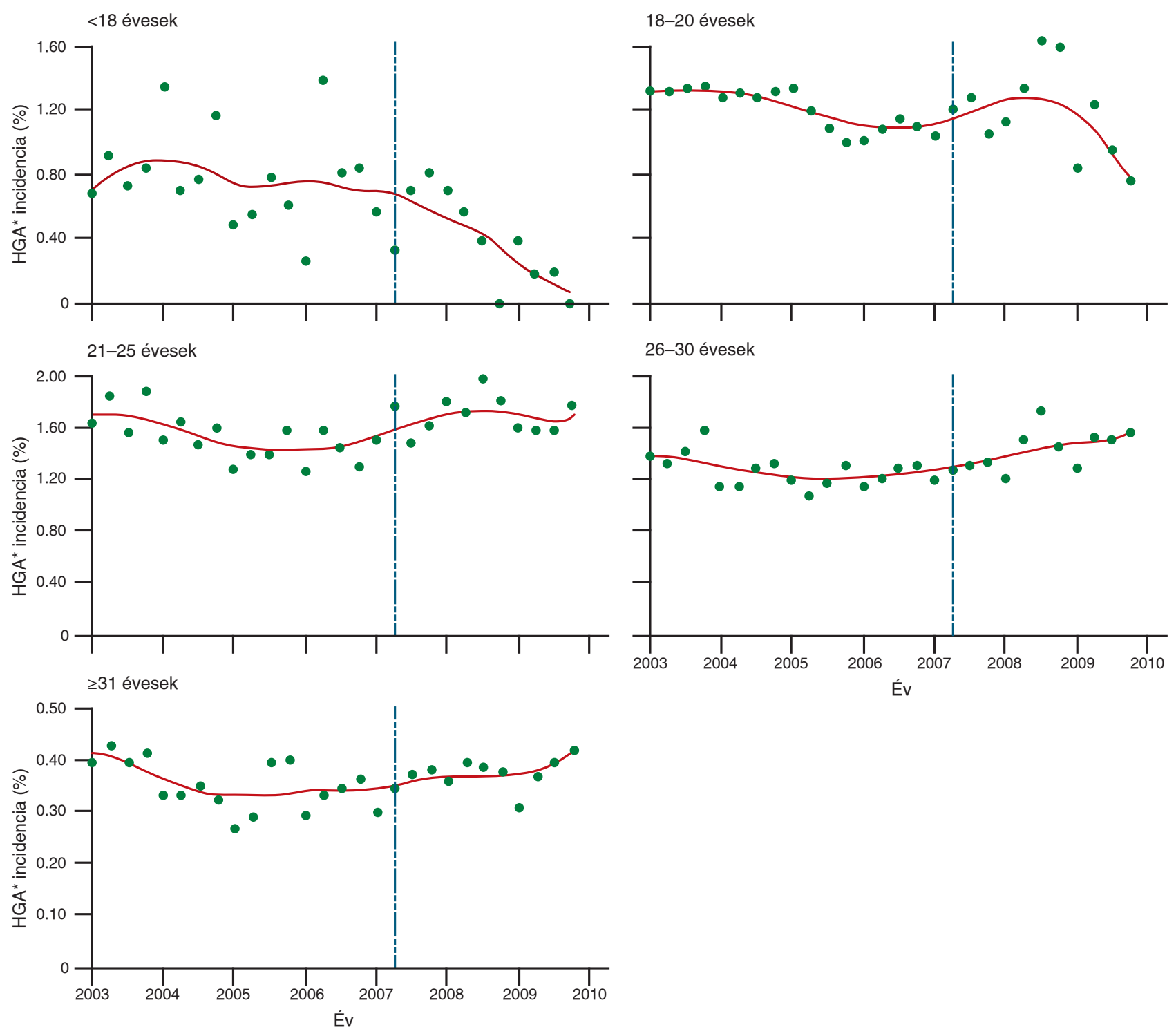

\begin{tabular}{l|l} 
1. ábra & $\begin{array}{l}\text { A méhnyak rákmegelőzó állapotainak (CIN 2+, AIS) incidenciája korcsoportonként } \\
\text { * } \mathrm{HGA}=\text { high-grade abnormality }\end{array}$
\end{tabular} 

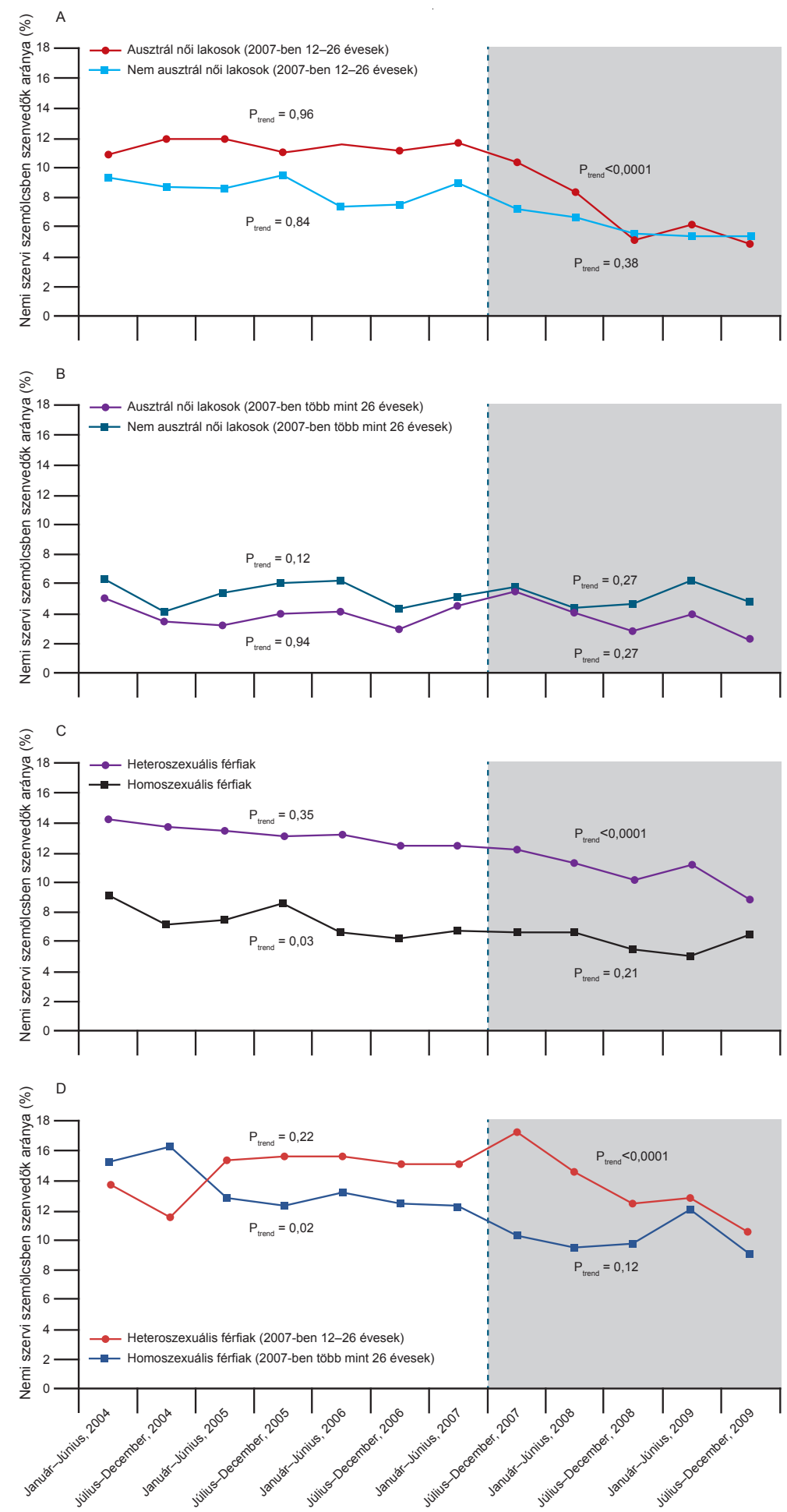

\section{Felhasznált irodalom}

[1] Brotherton, J. M. L., et al.: Early effect of the HPV vaccination programme on cervical abnormalities in Victoria, Australia: an ecological study. Lancet, 2011, 377, 2085-2092.

[2] Donovan, B., et al.: Quadrivalent human papillomavirus vaccination and trends in genital warts in Australia: analysis of national sentinel surveillance data. Lancet Infect. Dis., 2011, 11, $39-44$. 


\subsection{A HPV-vakcinák védőhatása populációs szinten (matematikai modellezés alapján)}

\subsubsection{A HPV-pakcinák társadalmi hatásának modellezése (a brit Health Protection Agency [HPA] elemzése)}

A széles körben publikált megfigyelések egyértelmúen bizonyítják, hogy a humán papillomavírus (HPV) okozta infekció a méhnyakrák kialakulásának meghatározó oki tényezője. Jelentős továbbá a szerepe az anogenitalis condylomatosis mellett a régió egyéb daganatainak kialakulásában is $[1,2,3]$. Az ingyenesen hozzáférhető vakcináció bevezetését megelőzően sor került az illető országokban a bivalens és kvadrivalens vakcina hatásának és költséghatékonyságának elemzésére. Az Egyesült Királyságban (UK) az ingyenes vakcinációs program 2008-ban indult el a 12-13 éves leányok korosztályában, amihez sporadikus, felzárkóztató vakcináció (catch-up) csatlakozott 18 éves korig.

A Brit Health Protection Agency munkatársainak 2011-ben publikált elemzése módszerként a szerzók 2008-as publikációjában kifejtett dinamikus transzmiszsziós modellt alkalmazta, aktualizálva azt a cikk megírásának időpontjára $[4,5]$. Az ökonómiai matematikai modell keretei közötti értékelés lényeges paramétere az alkalmazott 20 000-30 000 angol font/év QUALY(quality adjusted life year) érték, amely megfelel a költséghatékonyság National Institute of Health and Clinical Excellence (NICE) által használt gazdaságossági határértékének. Az aktualizálás lényeges eleme volt annak figyelembevétele, hogy a UK-ban a vakcinált HPV-típusok által igazolt méhnyakrákos megbetegedések száma emelkedést mutat. A modellben a HPV-16 és -18 által okozott méhnyakrákos megbetegedések aránya a laphámcarcinoma esetén $76,4 \%$, a mirigyhámcarcinoma esetén $81,9 \%$ értékkel került figyelembevételre [6].

A méhnyakrákon túl az egyéb daganattípusokkal szembeni védelem a kvadrivalens vakcina egyik fó értéke. A védőhatás magas evidenciaszintû́ vizsgálatok szerint kiterjed a vulva, a vagina és az anus rákmegelőző állapotaira, amelyek progressziója invazív rák kialakulását eredményezi. Lényeges észlelés, hogy a penis és az oropharynx rákos megbetegedései szintén kapcsolatban állnak a HPV 16/18 infekcióval $[2,7,8]$. A bivalens vakcina esetén nem történtek vizsgálatok az utóbbi daganattípusokra vonatkozóan. Az optimisztikus szcenáriók feltételezik, hogy a bivalens vakcina hatékonysága a 16/18 típusokkal szemben kiterjedhet a fenti lokalizációkra is, de ezt klinikai vizsgálatok nem erôsítették meg. Újabb közlések szerint a bivalens vakcina hatékony az analis infekciókkal szemben [9].

$\mathrm{Az}$ anogenitalis condylomamegbetegedések száma a UK-ban 156 000-re becsülhető évente [10], így jelentős betegségterhet képvisel. A kvadrivalens vakcina preventív spektrumának egyre emelkedő jelentőségú eleme ez a betegségcsoport. A low-grade citológiai elváltozások többségének hátterében ugyancsak HPV 6/11 infekció áll. Bár az elváltozás onkológiai jelentősége kisebb, számottevő költségterhet jelent a citológiai kenetek megismétlése, valamint a csatlakozó kolposzkópos vizsgálat a National Cervical Cancer Screening Programme adatai szerint. Mindezek figyelembevétele megtörtént a modell értékelése során. A rekurráló légúti papillomatosis fiatalkori és felnőttkori formája szintén a betegségteher része, és hangsúlyozandó, hogy a juvenilis forma $2 \%$-ban halálos kimenetelú.

A HPV-vakcinák hatékonyságának és a ráfordítások összegének lényeges befolyásoló tényezője az átoltottság elért szintje. A UK adatai szerint a 12-13 éves korosztály $84,1 \%$-a vette fel mindhárom oltást, $87,7 \%$-a minimálisan kettő, 89,8\%-a minimálisan egy dózisban részesült. A 13-17 év közöttiek 65\%-a, a 17-18 évesek $30 \%$-a került oltásra az úgynevezett catch-up csoporton belül. Az adatok részben becslésen alapszanak.

A vakcinák hatásának értékelése során a pontosságnak talán legjelentősebb limitáló tényezője az immunogenitás, a hatékonyság időtartama körüli bizonytalanság. A hatékonyság tartamát értékelő, az oltás utáni követés leghosszabb időtartama jelenleg a bivalens vakcina esetén a 16-os és 18-as típusra 7,3 év, a kvadrivalens vakcina 16-os típusára 9 év. Fontos megfigyelés, hogy az ellenanyagszint-csökkenés nem eredményezte „áttöréses” megbetegedések jelentkezését. A jelen tanulmányban alkalmazott, különböző forgatókönyvek szerinti hatékonysági és ráfordítási értékelést talán leginkább a hatékonyság időtartama pontos ismeretének hiánya teszi szükségessé. A tanulmány a következő három alternatíva szerint értékel: mindkét vakcina hatékonyságának időtartama 20 év, mindkét vakcina a teljes élettartamra biztosítja a védettséget, mindkét vakcina védelmet biztosít a teljes élettartamra, kivéve a kvadrivalens vakcina 6,11 és 18 -as típusát, ahol a védettség időtartama 20 év.

További, a többféle forgatókönyv szerinti értékelést indokló körülmény a keresztvédelem kiterjedtségére és annak időtartamára vonatkozó adatok körüli bizonytalanság. A modellben a kvadrivalens vakcina esetén a nem vakcinált típusok által okozott megbetegedésekre kiterjedő védőhatást $23,4 \%$-ra [10], a bivalens vakcinára 47,7\%-ra becsülték [11]. A különbség validitását megkérdőjelezi az alkalmazott vizsgáló és értékelési paraméterek különbözősége a két tanulmány során. További, a keresztvédelemmel kapcsolatos ellentmondásos paraméter a védelem valószínúleg a vakcinált típusokat jellemző́nél lényegesen rövidebb tartama. Így mindenképpen számolni kell olyan forgatókönyvekkel is, amelyek figyelembe veszik ezt a körülményt is.

A multiplex, több típussal történt egyidejü fertőzések értékelésének újabb módszere a „laser capture microdissection", amely lehetôvé teszi a daganatos szöveten belül jelen lévő, az adott daganat kialakulásáért felelős HPV-típus azonosítását. Ez utóbbi új megvilá- 
gításba helyezi a cross-protection kérdését, bizonyítva, hogy minden individuális daganat csak egy magas kockázatú HPV-típust tartalmaz [12]. Egyetlen modell sem számol jelenleg azzal a lehetőséggel, hogy a vakcinált típusok helyét egyre nagyobb arányban átvehetik kompetitív, ugyanakkor nem vakcinált típusok, a vonatkozó evidence-based vizsgálati eredmények hiányában.

A fenti, a vakcináció hatékonyságát lényegesen befolyásoló, ugyanakkor jelenleg még nem egyértelmű paraméterek megnehezíthetik a felhasználandó vakcina típusáról szóló döntést. Az utóbbi segítését szolgálja az olyan különböző forgatókönyvek szerinti elemzési modell, amely figyelembe veszi a fent részletezett, a vakcinák hatékonyságát és a költségráfordításokat egyaránt érintő paraméterek többféle konstellációját is. A HPA közleménye az említett változók kombinálásával 12 forgatókönyv szerint végez elemzést, az alábbiak szerint variálva a paramétereket:

- a védelem tartama a vakcinált és nem vakcinált HPVtípusokra - 20 év/teljes élettartam;

- a védelem által lefedett carcinomatípusok - bármilyen HPV-típus által okozott cervixcarcinoma;

- bármilyen HPV-típus által okozott minden típusú rák;

- bármilyen HPV-típus által okozott cervixcarcinoma és a vakcinált HPV-típusok által okozott minden egyéb típusú rák.

A célbetegségekre kifejtett hatást illetően a közlemény megállapítja, hogy a forgalomban lévő vakcinák várhatóan lényegesen csökkentik a HPV-infekció okozta megbetegedéseket, a vakcina típusától függetlenül. A hatékonyság szempontjából igen fontos, de jelenleg bizonytalan paraméter a hosszú távú hatékonyság tartama. A vakcinák által nyújtott haszon akkor a legjelentősebb, ha a teljes élettartamra érvényes hatástartammal számolhatunk. A költséghatékonyságot értékelő matematikai modellek szabályait követve jelen tanulmány is százéves periódust vesz figyelembe. A modell szerint a kvadrivalens vakcina 700-1000 méhnyakrákos megbetegedés megelőzésének évenkénti medián értékével számol, a bivalens vakcina esetén pedig 730-1100, annak függvényében, hogy a vakcinák hatástartamát és a keresztvédelem kiterjedtségét milyen adatokra támaszkodva adjuk meg. A különbség a méhnyakrák megelőzésének vonatkozásában nem mondható jelentősnek, annak ellenére sem, hogy a kalkuláció optimista forgatókönyvei a bivalens vakcina esetén azokat a közléseket veszik figyelembe, amelyek a vakcina szélesebb keresztvédelmére utalnak, továbbá kalkulálnak a kvadrivalens vakcina rövidebb hatékonyságtartamával a HPV-18 esetében. Ez a különbség nem lehet számottevő, mivel a méhnyakrákos megbetegedések túlnyomó többségét a HPV-16 típus okozza.

A modellnek ugyancsak a százéves értékelési intervallumával számolva 2109-re 620-950 nem cervicalis eredetű daganat megelőzése prognosztizálható. Amennyiben a vakcinák alkalmazási leírásaiban említett értékelési végpontokat vesszük figyelembe, a kvadrivalens vakcina 430-630 vulva-, vagina- és analis rák megelőzését biztosítja évente. A kvadrivalens vakcina ugyancsak jelentősen csökkenti (95\%) az anogenitalis condylomatosis és a rekurráló respiratorikus papillomatosis incidenciáját. A bivalens vakcina kapcsán említett 1,1-4,1\% előny a rákos halálozások csökkentését illetően csak a bivalens vakcina szempontjából optimális értékekkel számoló forgatókönyv szerint áll fenn, amely szerint mindkét vakcina biztosítja a védelmet a HPVinfekcióval kapcsolatos rákos daganatok teljes körét illetően. Ismert, hogy ilyen irányú vizsgálat nem történt a bivalens vakcinával.

A vakcinák által nyújtott egészséggazdálkodási haszon tekintetében a modell jelzi, hogy mindkét vakcina jelentős megtakarításokat biztosít, csökkentve a betegségcsoport által igényelt ráfordításokat, valamint ugyancsak csökkentve a megbetegedéscsoport által okozott, a QUALY által mért egészségromlást. Kiemeli az anogenitalis condylomatosis megelőzésének jelentőségét, amely a kvadrivalens vakcina alkalmazása mellett biztosított. Ezen megbetegedések incidenciája emelkedő tendenciát mutat, továbbá jelentős körülmény ökonómiai szempontból is, hogy ez a fajta védőhatás a vakcinációt követően már igen rövid időn belül is érzékelhető, csökkentve a kapcsolódó egészségügyi ráfordításokat. A jelenlegi epidemiológiai adatok, valamint a kapcsolatos, vakcinációra vonatkozó ökonómiai modellezés szerint a nem cervicalis rákokkal szembeni védelem egészségügyi szempontból igen jelentős lehet, de gazdasági súlya elmarad a méhnyakrák mögött.

A kvadrivalens vakcina modell szerint számított költséghatékonysága lényegesen az alkalmazott $30 \quad 000$ font/QUALY küszöbérték alatt tartható, ha a vakcina hatására vonatkozó bármelyik paraméterkombinációt vesszük figyelembe. Értéke a nem vakcinált populációhoz történt viszonyításban $12000-19000$ font, az anus, a penis és az oropharynx daganataival szembeni védelmet is figyelembe véve. Ugyancsak alacsony marad az érték - 22000 font - akkor is, ha csak az alkalmazási leírásban szereplő indikációkat tekintjük. A bivalens vakcina hasonló teljesítménye magasabb költségvonzatú, 16 000-25 000 font, egy szélesebb daganatellenes hatást értékelő végpont-konstelláció mellett, és tovább romlik a költséghatékonyság, ha csak az alkalmazási előírásban szereplő végpontokat vesszük figyelembe. Az utóbb említettekből következik, hogy a modell kedvezőtlenebb forgatókönyve szerint, amely nem veszi figyelembe a bivalens vakcina feltételezett, de nem bizonyított védőhatását a nem cervixeredetú daganatok vonatkozásában, a bivalens vakcináció nem tekinthető költséghatékonynak a modellben alkalmazott dózisonkénti 84,5 font ár mellett. A kvadrivalens vakcina által hordozott hozzáadott értéket, ha csak a vakcinák alkalmazási előírásaiban szereplő megbetegedések megelőzését vesszük figyelembe, 48-68 font árkülönbség fejezheti ki. Előtérbe került továbbá az a tény is, hogy a kvadrivalens vakcina által biztosított klinikai végpontú vizsgálatokkal bizonyított védelem az anogenitalis condylomatosissal szemben a modellben magasabb szinten 
értékesül, mint a bivalens vakcina által biztosított virológiai és immunológiai végpontú vizsgálatokkal bizonyított nagyobb fokú keresztvédelem, és a magasabb ellenanyagszint.

A vakcinációt térítésmentesen bevezető országok döntéshozatalához nélkülözhetetlen hasonló, a költséghatékonyságra vonatkozó modellek készítése és értékelése $[13,14]$. Ugyanakkor kevés azon vizsgálatok száma, amelyek fölvállalnák a bivalens és kvadrivalens vakcina ára közti reális különbség, az értékarányos ár meghatározásának feladatát. Egy ír tanulmány [15] szerint a bivalens vakcina értékarányos árának 22\%-kal kell alatta lenni a kvadrivalens vakcina árának, és a különbséget elsősorban az anogenitalis condyloma elleni védelemmel indokolja. Egy kanadai tanulmány 35 dollárban állapítja meg az indokolt árkülönbözetet [16].

Természetesen a jelen modell szerinti vizsgálatnak is megvannak a korlátai. Maguk a gyártók is igyekeznek kiemelni a vakcinák közti különbségeket, elsősorban azok összetétele (valencia és adjuváns), a védelem kiterjedtsége, az immunogenitás tartama és a nem vakcinált típusokkal szembeni védelem területén. Ugyanakkor sok esetben nem egyértelmü, hogy a fenti paraméterek milyen hatással vannak a vakcina hatékonyságára azok széles körű alkalmazása esetén, azaz populációs szinten. Példaként említhető, hogy az immunogenitás nem bizonyult a klinikai védelem megbízható markerének, továbbá, hogy a nem vakcinált típusokra kiterjesztett keresztvédelem nem bizonyul a gyakorlatban tartósnak. A bivalens vakcina nem cervicalis kiindulású daganatokkal szemben biztosított protektív hatása nem bizonyított a gyártó által, de ennek ellenére feltételezhető. Ugyancsak nehezíti az értékelést, hogy a keresztvédelem igazolása szükségessé tenné a megbetegedést ténylegesen okozó vírustípus meghatározását a jelenlegi experimentális vizsgálatokat lényegesen meghaladó körben, aminek korlátja a vizsgálatok költségessége és magas szintü laboratóriumi háttérigénye.

Mindezen körülmények figyelembevételét tükrözi, hogy Jit és munkatársainak 2011-ben publikált közleménye a két vakcina differenciált költséghatékonysági elemzése során alkalmazott modellben fel kellett hogy vállalja a fenti variációk figyelembevételével elkészített többféle forgatókönyv szerint elvégzett értékelést. A többféle forgatókönyv szerinti elemzés egyik jelentős tanulsága, hogy a modell figyelemre méltó különbségeket észlelt annak függvényében, hogy a vakcina hatástartamára, a keresztvédelem mértékére és a nem cervicalis daganatokkal szembeni védelemre vonatkozó adatok mely konstellációját veszi figyelembe az értékelt vakcinák esetén.

Összegzésképpen elmondható, hogy a népegészségügyi döntéshozás során nem lehet eltekinteni a vakcinák hatékonyságára vonatkozó, magas evidenciaszintú tanulmányok publikált eredményeitől. A vakcinákra vonatkozó adatokat a maguk súlyának, evidenciaszintjének megfelelően kell értékelni. A jelenleg rendelkezésre álló evidenciák a bivalens vakcina hatását a méhnyakrák megelőzésének területén igazolták. Mindenképpen a döntést meghatározó lényeges körülmény, hogy a kvadrivalens vakcina hatása ezen túlmenően bizonyítást nyert a HPV-asszociált nem cervicalis daganatok széles körében és az anogenitalis condyloma megelőzése terén is. A hatékonyság körének ökonómiai vonzataként kezelendő a költséghatékonyság. A kvadrivalens vakcinát bizonyítottan széles körü hatékonysági adatai kedvezőbb költséghatékonysági szintre emelik.

\section{Felhasznált irodalom}

[1] Bosch, F. X., Lorincz, A., Munoz, N., et al.: The casual relation between human papillomavirus and cervical cancer. J. Clin. Pathol., 2002, 55, 244-265.

[2] Parkin, D. M., Bray, F.: Chapter 2: The burden of HPV-related cancers. Vaccine, 2006, 24 (suppl 3), S3-11-S3/25.

[3] Clifford, G.: The growing evidence of an epidemiological link between oral cancers and HPV. Presented at EUROGIN 2010, Monte Carlo, Monaco, Feb. 20, 2010.

[4] Jit, M., Chapman, R., Hughes, O., et al.: Comparing bivalent and quadrivalent human papillomavirus vaccines: economic evaluation based on transmission model. BMJ, 2011, 343, d5775. Doi: $10.1136 /$ bmj.d5775

[5] Jit, M., Choi, Ү. H., Endmunds, W. J.: Economic evaluation of human papillomavirus vaccination in the United Kingdom. BMJ, 2008, 337, a769.

[6] Howell-Jones, R., Bailey, A., Beddows, S., et al.: Multi-site study of HPV type-specific prevalence in women with cervical cancer, intraepithelial neoplasia and normal cytology, in England. Br. J. Cancer, 2010, 103, 209-216.

[7] Joura, E. A., Leodolter, S., Hernandez-Avila, M., et al.: Efficacy of a quadrivalent prophylactic human papillomavirus (types 6,11 , 16 and 18) Ll virus-like-particle in against high-grade vulval and vaginal leions: a combined analysis of three randomised clinical trials. Lancet, 2007, 369, 1693-1702.

[8] Giuliano, A. R., Palefsky, J. M., Goldstone, S., et al.: Efficacy of quadrivalent $\mathrm{HPV}$ vaccine against $\mathrm{HPV}$ infection and disease in males. N. Engl. J. Med., 2011, 364, 401-411.

[9] Kreimer, A. R., González, P., Katki, H. A., et al.: Efficacy of a bivalent HPV 16/18 vaccine against anal HPV 16/18 infection among young women: a nested analysis within the Costa Rica Vaccine Trial. Lancet Oncol., 2011, 12, 862-870.

[10] Desai, S., Wetten, S., Woodhall, S. C., et al.: Genital warts and cost of care in England. Sex. Transm. Infect., 2011, 87, 464-468.

[11] Tjalma, W., Paavonen, J., Naud, P., et al.: Efficacy of the HPV16/18 AS04-adjuvanted vaccine against abnormal cytology and low-grade histopathological lesions in an oncogenic HPVnaive population. Presentation at the 16th International Meeting of the European Society for Gynaecological Oncology, Belgrade, October 11-14, 2009. Int. J. Gynecol. Cancer, 2009, $19,1-1024$.

[12] Quint, W., Moljin, A., Colau, B., et al.: One HPV virus, one lesion as determined by LCM/PCR technology. Abstract 06.04 25th International Papillomavirus Conference, Malmö, Sweden, 2009.

[13] Stern, P. L.: For debate: that Australia should consider changing to the bivalent vaccine. Sex. Health, 2010, 7, 238-241.

[14] Haas, M., Ashton, T., Blum, K., et al.: Drugs, sex, money and power: an HPV vaccine case study. Health Policy, 2009, 92, 288-295

[15] Dee, A., Howell, F.: A cost-utility analysis of adding a bivalent or quadrivalent HPV vaccine to the Irish cervical screening programme. Eur. J. Public Health, 2010, 20, 213-219.

[16] Brisson, M., Van de Velde, N., De Wals, P., et al.: The potential cost-effectiveness of prophylactic human papillomavirus vaccines in Canada. Vaccine, 2007, 25, 5399-5408. 


\subsection{A HPV-vakcinák biztonságossági profilja}

A védőoltásokkal szemben támasztott biztonságossági követelmények szigorúbbak, mint a legtöbb gyógyszerrel szemben támasztott követelmények, mivel az oltóanyag egy biológiai termék és széles tömegek immunizálására szolgál.

Annak ellenére, hogy az oltóanyagokat számos szigorú biztonsági tesztnek vetik alá forgalomba hozatal előtt, a klinikai vizsgálatokban részt vevők száma nem elég nagy ahhoz, hogy a ritka mellékhatások kockázatát teljes biztonsággal felmérjék (10 000-100 000 oltásból egy esetben jelentkező mellékhatás-kockázat).

A forgalomba hozatali engedély kiadását követő folyamatos megfigyelés elengedhetetlenül szükséges a biztonságossági profil megállapítására. A HPV-vakcinák vonatkozásában is ez a monitoringrendszer múködik. A megfigyelések azt igazolják, hogy mindkét HPVvakcina jól tolerálható, hasonló biztonságossági profillal rendelkezik.

\subsubsection{A bivalens vakcina biztonságossága (alkalmazási elöirás) [1]}

A bivalens vakcinával végzett klinikai vizsgálatokban 16142 lány/nő részesült Cervarix oltásban, míg 13811 lány/nő kontrollanyagot kapott. Ezeknél az egyéneknél a vizsgálat teljes időtartama alatt követték a súlyos nemkívánatos események előfordulását.

A vakcina beadását követően észlelt leggyakoribb mellékhatás az oltás helyén fellépő fájdalom volt, ami az összes adag 78\%-ának beadása után előfordult. Ezen reakciók többsége enyhe vagy közepes súlyosságú volt és nem volt tartós.

Az egyes mellékhatások előfordulási gyakorisága klinikai vizsgálatokban:

Nagyon gyakori $(\geq 1 / 10)$ :

- Az injekció beadásának helyén fellépő reakciók, így fájdalom, bőrpír, duzzanat.

- Fáradékonyság.

- Fejfájás.

- Izomfájdalom.

Gyakori $(\geq 1 / 100-<1 / 10)$ :

- Emésztőrendszeri tünetek, így hányinger, hányás, hasmenés és hasi fájdalom.

- Viszketés/pruritus, bőrkiütés, urticaria.

- Ízületi fájdalom.

- Láz $\left(\geq 38^{\circ} \mathrm{C}\right)$.

Nem gyakori $(\geq 1 / 1000-<1 / 100)$ :

- Felső légúti fertőzések.

- Szédülés.

- Az injekció beadásának helyén fellépő egyéb reakciók, például induratio, helyi paraesthesia.
A forgalomba hozatalt követően a következő mellékhatásokat jelentették spontán (gyakoriságukat nem lehet megbízható módon megbecsülni):

- Lymphadenopathia, allergiás reakciók (anaphylaxiás és anaphylactoid reakciókat is beleértve), angiooedema, az injekció kiváltotta ájulás vagy vasovagalis válasz (néha tónusos-clonusos mozgások kíséretében).

\subsubsection{A kvadrivalens vakcina biztonságossága (alkalmazási elöírás) [2]}

Hét klinikai vizsgálatban (hat placebokontrollos) a vizsgálati személyek a vizsgálatba való bevonásuk napján és mintegy két és hat hónappal azután Silgardot vagy placebót kaptak. Kevés vizsgálati személy $(0,2 \%)$ hagyta abba a vizsgálatot mellékhatások miatt. A biztonságosságot a teljes vizsgálati populációban (hat vizsgálat) vagy a vizsgálati populáció előzetesen kiválasztott alcsoportjában (egy vizsgálat) vakcinációs mellékhatás-jelentő lapok segítségével értékelték a Silgard, illetve a placebo minden egyes dózisának beadását követő 14 nap során. Azok közül, akiket vakcinációs mellékhatás-jelentő lapok segítségével monitoroztak, 10088 személy (6995, a bevonáskor 9-45 éves leány vagy nő és 3093, a bevonáskor 9-26 éves fiú vagy férfi) kapott Silgardot, 7995 (5692 leány vagy nő és 2303 fiú vagy férfi) pedig placebót.

A leggyakrabban megfigyelt mellékhatások az injekció beadásának helyén fellépő mellékhatások (a beoltottak 77,1\%-ánál, bármelyik vakcináció után öt napon belül léptek fel) és a fejfájás voltak (a beoltottak 16,6\%-ánál lépett fel). Ezek a mellékhatások általában enyhe-közepes intenzitásúak voltak.

Nagyon gyakori $(\geq 1 / 10)$ :

- Az injekció beadásának helyén: erythema, fájdalom, duzzanat.

- Fejfájás.

Gyakori $(\geq 1 / 100-<1 / 10)$ :

- Hányinger.

- Végtagfájdalom.

- Láz $\left(\geq 38^{\circ} \mathrm{C}\right)$.

- Az injekció beadásának helyén: heamatoma, pruritus.

Nem gyakori $(\geq 1 / 1000-<1 / 100)$ :

- Felső légúti fertôzések.

- Szédülés (csak nőknél volt gyakoribb a vakcinát kapó csoportban a placebocsoporthoz viszonyítva, férfiaknál nem).

- Az injekció beadásának helyén fellépó egyéb reakciók, például induratio, helyi paraesthesia.

Ritka ( $\geq 1 / 10000-<1 / 1000)$

- Urticaria - kilenc esetben $(0,06 \%)$ jelentettek urticariát a Silgard-csoportban és 20 eset $(0,15 \%)$ került jelentésre az adjuvánst tartalmazó placebocsoportban.

Nagyon ritka $(<1 / 10000)$ :

- Bronchospasmus. 
A forgalomba hozatalt követően a Silgard világszerte történő alkalmazása során spontán jelentett nemkívánatos eseményeket is folyamatosan rögzítik. Mivel ezeket az eseményeket egy bizonytalan nagyságú betegcsoportból, önkéntesen jelentették, gyakoriságukat, illetve az összes eseményre vonatkozóan a vakcinációval való okokozati összefüggést nem mindig lehet megbízhatóan megbecsülni. Következésképpen ezeknek a nemkívánatos eseményeknek a gyakorisága a „nem ismert” kategóriában kerül besorolásra.

A következő mellékhatásokat jelentették a forgalomba hozatalt követően:

- Cellulitis az injekció beadása helyén, idiopathiás thrombocytopeniás purpura, lymphadenopathia, túlérzékenységi reakciók, Guillain-Barré-szindróma, eszméletvesztés, némely esetben tónusos-clonusos mozgásokkal kísérve, arthralgia, myalgia, asthenia, hidegrázás, fáradtság, rossz közérzet.

\section{Felhasznált irodalom}

[1] Cervarix alkalmazási elöírás: http://ec.europa.eu/health/ documents/community-register/html/alfregister.htm

[2] Silgard alkalmazási elő́rás: http://ec.europa.eu/health/ documents/community-register/html/alfregister.htm 


\section{Javaslat a HPV okozta megbetegedések megelözésének népegészségügyi programjára}

\subsection{A jelen: szekunder prevenció méhnyakrákszüréssel}

\subsubsection{Hazai átszûrési adatok}

A méhnyakszűrés két típusa van jelen hazánkban. Szervezett méhnyakszúrésrôl beszélünk, amikor a szúrés kezdeményezője a hatóság, illetve annak képviselője, és annak értesítése alapján jelentkezik a lakosság szürésre. Ezt a formát nevezzük másképp behívásos rendszerú szürésnek [1]. A szưrés kezdeményezője tehát a szűrés szolgáltatója, ha közvetett formában is. A szürés másik típusa esetén a szúrés kezdeményezője a lakosság, amikor is „opportunisztikus” szúrést említ a vonatkozó szakirodalom. A gyakorlatban ez azt jelenti, hogy a nói lakosság szúrés céljából vagy egyéb okból felkeresi az állami vagy magánüzemeltetésű nőgyógyászati szakrendeléseket. Mindkét esetben a szúréseket nőgyógyász szakorvosok végzik. Történt próbálkozás a behívásos rendszerú szűrésen belül a méhnyakszűrésre kiképzett egészségügyi szakdolgozók által végzett szüréssel is. A hazai méhnyakszúrési gyakorlat szerint a méhnyakszúrés elindítása a nemi élet elkezdésével együtt ajánlható. A szürési intervallum tekintetében egy és három év közötti ajánlások fogalmazódtak meg az elmúlt évtized során.

A nyugat-európai és tengerentúli tapasztalatok szerint az onkológiai epidemiológiai mutatók (jelen esetben a méhnyakrákos morbiditás és mortalitás csökkenése) jelentős, kedvező irányú változása a két típus közül csak a behívásos rendszerú tömegszúréssel biztosítható. Mindezt hazai tapasztalatok is alátámasztják, jóllehet, amennyiben egy adott országban az opportunisztikus szưrés volumene jelentôs, nem hagyható annak szerepe figyelmen kívül [2]. Összehasonlítva egy olyan időszakot, amikor csak az opportunisztikus szúrés volt hozzáférhető egy későbbi időszakkal, amikor már a behívásos rendszer is múködött, a szúrések számának országosan mintegy 82 000-rel való növekedése volt észlelhetô, ami tükröződött a hároméves szúrési lefedettség javulásában is. Ugyanakkor hangsúlyoznunk kell, hogy a szürés optimális hatékonyságának feltétele a minimálisan 70\%-ot elérő lefedettség.
Magyarországon a szervezett, behívásos méhnyakszüréseken történő megjelenési arány emelésére, a szürési lefedettség javítására több népegészségügyi program $[3,4]$ keretében is történt próbálkozás. Ennek ellenére, bár észlelhetó javulási tendencia, a szúrési lefedettség kevéssé emelkedett és jelenleg is alacsony. A publikált országos adatok szerint a szervezett szúrés bevezetését követően [2] az egyéves lefedettségi arány az értékelt évek egyikében sem érte el a 20\%-ot $(16,3-16,8 \%)$. A hároméves lefedettségi arány 32,9\% értéket mutatott, szemben a nyugat-európai, többnyire a 60\%-ot meghaladó átlagos lefedettséggel. A lefedettségi paraméterek mutathatnak kisebb eltéréseket mindkét irányban értékelési időszakonként, régiónként és talán leginkább korcsoportonként. A hazai, egyébként viszonylag magas lefedettséggel $(52,6 \%)$ jellemezhető 45-64 éves korosztály esetében, sajnos, többnyire a „szűrés” már elkésett, nem rákmegelőző állapotra vagy korai stádiumú tünetmentes méhnyakrákra derít fényt, hanem kedvezőtlen prognózisú, esetenként előrehaladott stádiumú daganatra, így nem is tekinthetố valóban szúrésnek. Különösen kedvezőtlen ez az adat, ha figyelembe vesszük azt a HPV-infekciók kóroki jelentőségével kapcsolatos megfigyelést, hogy a méhnyakrák kialakulásának predilekciós életkora egyre fiatalabb korosztályra tevődik át.

\subsubsection{Az elkeriult betegségek és halálozások becsült száma}

A méhnyakszúrés hatékonyságának abszolút mutatója a méhnyakrákos halálozások számának csökkenése a szûrt populációban. Ugyanakkor a szürés hatékonyságát korábban is jelezhetik egyéb epidemiológiai paraméterek. Az elsố ilyen mutató a korai stádiumú, optimális esetben rákmegelőző stádiumban felismert esetek számarányának növekedése a stádiummegoszlás következményes eltolódásával a jobb prognózisú korai stádiumok irányába. Ez utóbbi eredményezi a hosszabb túlélést és tükröződik majd a mortalitás javulásában. Az incidencia, a prevalencia, majd a mortalitás következményes csökkenése tehát csak a szûrés elkezdését követően évekkel, évtizedekkel később bontakozik ki. 
Nagy szürési hagyományokkal rendelkező országok adataiból a hazai viszonyokra extrapolációt végezni [5, $6,7,8$ ] a jelenlegi alacsony lefedettségi adatok mellett csak közelítőleg és mintegy teoretikusan lehetséges. Legkorábban mintegy két évtizeddel a megfelelő lefedettséggel végzett méhnyakszürés bevezetését követően lenne várható a hazai incidencia 20 körüli értékről egy nagyságrenddel való csökkenése. A méhnyakrákos mortalitásnak a hazai 10 feletti értékról 2 körüli értékre való csökkenése még ennél is későbbre tehető. Mindez a csökkenés természetesen csak a 90\%-ot megközelítő lefedettség mellett várható el.

Az elkerülhető betegségek és halálozások számának csökkenése a fentiek előrebocsátásával becsülhető meg. Hazánkban évente, az elmúlt évek átlagában, mintegy 1100 új méhnyakrákos megbetegedés került felismerésre. A szüréseket hároméves intervallumokkal végezve, a lefedettséget 90\%-ra emelve a 2030-as évekre lenne várható a méhnyakrákos megbetegedések 100 újonnan felismert megbetegedés/év értékre csökkenése.

A hazai méhnyakrákos megbetegedésekre visszavezethető elhalálozások évi száma az elmúlt évek átlagában mintegy 500-ra tehető. A korábban említett szúrési paraméterek mellett és a lefedettség lényeges javulása esetén legkorábban hat-nyolc szürési ciklust követően, a 2030-as évek második felében csökkenhetne az 50-es érték alá a méhnyakrákban évente elhaltak száma hazánkban.

Ugyanakkor a Magyarországon regisztrált 30\% körüli lefedettség mellett mindezen redukciók a méhnyakrák morbiditásában és mortalitásában nem teljesíthetők a szekunder prevenció napjainkban gyakorolt formájával. A hazai morbiditás és mortalitás csökkenésének mértéke várhatóan alacsonyabbnak bizonyul majd a példákban említetteknél. Epidemiológiai értelemben is jelentős javulás kevéssé valószínű, ugyanis a szekunder prevenció kedvező hatását elfedhetik a nem szûrt populációban folyamatosan és jelentős számban kialakuló invazív méhnyakrákos megbetegedések. Így tehát mindenképpen indokolt lenne a hagyományos méhnyakszürést támogató egyidejű primer prevenciós eljárás széles körû alkalmazása is, megakadályozandó az új esetek folyamatos újrapótlódását. Csak egy ilyenfajta komplex prevenciós stratégiától várható a méhnyakrákban megbetegedettek és a méhnyakrákos megbetegedésben elhaltak számának számottevő hazai csökkenése.

\subsection{A javasolt primer+szekunder prevenciós stratégia}

\subsubsection{Elkerülhetō betegségek és halálozások becsült száma}

A méhnyakrák primer prevenciójának módszere a HPVinfekcióval szemben védelmet nyújtó vakcináció. A nemzetközi tapasztalatok szerint a vakcináció ideális idő- pontja 12 éves életkorra tehető [9]. Ez az életkor nagy valószínúséggel a szexuális élet elkezdése előtti időszakra esik a magyarországi leánygyermekek meghatározó többségénél. Epidemiológiai felmérések szerint a HPV-infekciók prevalenciája csúcsértékét a késői tizenévesek és a huszonévesek korosztályában éri el. A méhnyak rákmegelőző állapotok prevalenciája mintegy 10 évvel későbbi életkorban észlelhető. Az invazív méhnyakrák legmagasabb prevalenciaértékei pedig a 40-50 év közötti életkorban regisztráltak [10]. A méhnyakrákszűrés klasszikus modellje az ismételt citológiai kenetvételeket és kolposzkópos vizsgálatokat foglalja magában. A klasszikus szûrés az utóbbi években HPV-teszttel került kiegészítésre.

A hagyományos modellbe a serdülőkorú lányok vakcinációját beillesztve történtek becslések az elkerülhető betegségek és halálozások becsült számára vonatkozóan. Az Amerikai Egyesült Államok vonatkozó epidemiológiai adatbázisa alapján (a HPV-prevalencia 1417\%, a HRHPV-fertőzések aránya 59\%, a standardizált méhnyakrák mortalitása 2,7/100 000, a kétéves intervalummal történt átszürtség 70\%), 250 leány 12 éves kori vakcinálása eredményezheti egy méhnyakrákos halálozás megelőzését [11]. A hazai epidemiológiai helyzet kedvezőtlenebb (HPV-prevalencia: 17-25\%, HRHPV: $80 \%$, standardizált méhnyakrákos mortalitás: 6,1/100 000, kétéves szürési lefedettség 30\%), így a vakcináció erőteljesebb hatása várható, és már 130 gyermek beoltása is eredményezhetné egy méhnyakrákos megbetegedés megelőzését [12]. A vakcinációban nem részesült és a 12 éves korban vakcinált leányok epidemiológiai adatait összehasonlító becslések szerint a HPV okozta megbetegedések számának csökkenése egyértelmú. Ez a kedvező hatás a kvadrivalens vakcina alkalmazása esetén legkorábban a genitalis condylomamegbetegedések számának csökkenésében észlelhető, de már a vakcinációt követó évtizedben jelentkezik a rákmegelőző állapotok incidenciája terén is $[13,14$, 15]. Értelemszerüen később csökken az invazív méhnyakrákos megbetegedések száma, majd évtizedekkel később várható a mortalitás csökkenése. A 12 éves korosztály oltási program szerinti vakcinációját kiegészítheti a már szexuálisan aktív fiatal nők felzárkóztató oltása is.

Real-life típusú vizsgálatok eredményei bizonyítják, hogy azokban az országokban, ahol ingyenes vakcinációs programok múködnek, biztosítva az adolescens korosztály mintegy 80\%-os átoltottságát, a vakcinációs program elkezdését követően három-öt évvel már kimutatható az oltott populációban a cervicalis rákmegelőző állapotok előfordulási gyakoriságának csökkenése [16]. Kvadrivalens vakcinát alkalmazva a HPV 6/11 típus által okozott genitalis condyloma acuminatum megbetegedések számának csökkenése szintén megfigyelhető, sőt korábban és nagyobb mértékben, továbbá következményes védőhatás mutatható ki a nem oltott szexuális partnerek körében is [16, 17]. 
A primer prevenció, a HPV-vakcináció esetén is a széles körben történő alkalmazás, az oltási lefedettség az epidemiológiai értelemben vett hatékonyság alapfeltétele. Az oltási igény, a lakosság érdeklődése a HPVvédőoltás iránt a komplex problémakör jelentős tényezője [18]. Ezen a téren a tájékoztatás, az egészségügyi nevelés jelentősége, hasonlóan a hagyományos szüréshez, meghatározó. Így hasznos lenne a megelőzés két módszerének, a primer és szekunder prevenciónak együttes népszerúsítése és gyakorlása a méhnyakrákmegelőzési programok keretében. Az oltási lefedettség további fontos tényezője a ma még hazai viszonylatban meglehetősen költséges oltásokhoz való hozzáférés támogatása egy rendelkezésre álló vagy erre a célra létrehozott prevenciós alapból. Mindezen tényezők kedvező összehangolásától és együttes hatásától várható a hazai méhnyakrákos morbiditás és mortalitás kedvezőbbé válása.

\section{Felhasznált irodalom}

[1] Döbrőssy, L. (szerk.): Szervezett szűrés az onkológiában: minőségbiztosítási kézikönyv és módszertani útmutató. Egészségügyi Minisztérium, Budapest, 2000.

[2] Boncz, I., Sebestyén, A., Döbrössy, L., et al.: A méhnyakszürés részvételi mutatói Magyarországon. Orv. Hetil., 2007, 148, $2177-$ 2182.

[3] Döbrőssy, L.: Méhnyakszűrés 5 évtizede Magyarországon. Nőgyógyászati Onkológia, 2007, 12, 5-9.

[4] Hungarian National Cancer Control Program (HNCCP). Available at: http://www.cancerworld.org/cancerworldadmin/ getStaticModFile.aspx?id=1683. Accessed November 24, 2007.

[5] Sasieni, P. D., Adams, J.: Analysis of cervical cancer mortality and incidence data from England and Wales: evidence of a benefitial effect of screening. J. Roy. Stat. Soc. (A), 2000, 163, 191.

[6] World Health Organization: Trends in cancer incidence and mortality. International Agency for Research on Cancer. Lyon, 1993.
[7] Boncz, I., Sebestyén, A., Pál, M., et al.: A méhnyakrák szưrésének egészség-gazdaságtani elemzése. Orv. Hetil., 2003, 144 (15), 713-717.

[8] Vokó, Z., Nagyjánosi, L., Margitai, B., et al.: Modeling costeffectiveness of cervical cancer screening in Hungary. Value Health, 2012, 15 (1), 39-45.

[9] Saslow, D., Castle, P. E., Cox, J. T., et al.: American Cancer Society Guideline for human papillomavirus (HPV) vaccine use to prevent cervical cancer and its precursors. CA Cancer J. Clin., 2007, 57, 7-28.

[10] Schiffman, M., Castle, P. E.: The promise of global cervicalcancer prevention. N. Engl. Med. J., 2005, 353, 2101-2104.

[11] Sanders, G. D., Taira, A. V.: Cost-effectiveness of a potential vaccine for human papillomavirus. Emerg. Infect. Dis., 2003, 9 (1), 37-48.

[12] Nagy, L.: Költség-hatékonysági megfontolások a méhnyakrák megelőzésében: citológiai szűrés és vakcinációval történő prevenció. IME, 2006, 5, 26-33.

[13] Elbasha, E. H., Dasbach, E. J., Insinga, R. P.: Model for assessing human papillomavirus vaccination strategies. Emerg. Inf. Dis., 2007, 13, 28-41

[14] Garnett, G. P., Kim, J.J., French, K., et al.: Chapter 21: modeling the impact of HPV vaccines on cervical cancer and screening programmes. Vaccine, 2006, 24, 178-186.

[15] Dasbach, E. J., Nagy, L., Brandtmüller, A., et al.: The cost effectiveness of a quadrivalent human papillomavirus vaccine (6/ $11 / 16 / 18$ ) in Hungary. J. Med. Econ., 2010, 13 (1), 110-118.

[16] Brotherton, J., Fridman, M., May, C. I., et al.: Early effect of the HPV vaccination programme on cervical abnormalities in Victoria, Australia: an ecological study. Lancet, 2011, 377, 2085-2092.

[17] Woodhall, S. C., Jit, M., Cai, C., et al.: Cost of treatment and QALYs lost due to genital warts: Data for the economic evaluation of HPV vaccines in the United Kingdom. Sex. Transmitt. Dis., 2009, 36 (8), 515-521.

[18] Marek, E., Dergez, T., Kricskovics, A., et al.: Difficulties in the prevention of cervical cancer: Adults' attitudes towards HPV vaccination 3 years after introducing the vaccine in Hungary. Vaccine, 2011, 29, 5122-5129. 


\subsection{A HPV elleni népegészségügyi program szervezeti és múködési feltételei}

\subsubsection{A gyermekkori/serdülókori védöoltási kampány implementációja}

A nemzeti immunizációs programok alapvető célja, hogy a lakosság védelmét védőoltások alkalmazásával biztosítsák a súlyos fertőző betegségekkel és azok szövődményeivel szemben.

Az új vakcinák egy nemzeti programba történő bevezetésének két fontos feltétele van, az első egy szakmai ajánlás a tanácsadó testület részéről, és ezt követően, a szakmai ajánlás alapján, döntés az egészségügyi hatóság részéról.

A HPV-vakcinációs programok integrációja a nemzeti oltási programokba Európában 2006-ban kezdődött, amikor Ausztriában, ezt követően 2007-ben még hét további országban, majd 2012 januárjáig összesen 23 országban került integrálásra a HPV-prevenciót szolgáló vakcináció.

A hazai és nemzetközi tapasztalatok alapján kialakított oltási rend érvényesülését az egészségügyről szóló 1997. évi CLIV. törvény, továbbá annak a járványügyre vonatkozó rendelkezései [a többszörösen módosított 18/1998. (VI. 3.) NM rendelet] biztosítják.

Az Országos Epidemiológiai Központ Módszertani levele a védőoltásokról a fertőző betegségek és a járványok megelőzése érdekében szükséges járványügyi intézkedésekról szóló 18/1998. (VI. 3.) NM rendeletben kapott felhatalmazás alapján az Országos Epidemiológiai Központ által meghatározott, az adott évi védőoltási tevékenységre vonatkozó hazai gyakorlati feladatokat, továbbá az oltásokkal kapcsolatos általános és specifikus indikációkat, kontraindikációkat, az oltóanyagok beszerzésére, tárolására, felhasználására, az oltási nyilvántartásokra, jelentésekre vonatkozó kötelezettségeket, előírásokat, illetve ajánlásokat foglalja össze.

A hazai védőoltási gyakorlat tradicionálisan kiemelkedő eredményekkel rendelkezik.

A kötelező oltási rendben folyamatos és kampányoltások formájában történik a gyermekek immunizációja. Mindkét oltási rendnek számos előnye, illetve hátránya van, akár kötelező, akár önkéntes az oltás. A célkitűzés határozza meg a választandó oltási rendszert.

Folyamatos oltások elónyei:

- az orvos jól ismeri a gyermek egészségügyi állapotát, kórtörténetét;

- a tájékoztatás személyre szabottan történik;

- előnyösebb a helyzet kontraindikációk mérlegelésére;

- a szülők, serdülők bizalma nagyobb a választott orvossal szemben;

- edukációs lehetőség az egészséges páciens részére.
Folyamatos oltások hátrányai:

- időben elhúzódó lehet;

- serdülőkorúaknál a szülői közremúködés hiánya;

- szülő és gyermek/serdülő közös egybehangzó döntése szükséges a nem kötelező oltások végrehajtásához.

Kampányoltások elönyei:

- az oltandó korcsoport könnyú elérése;

- magas átoltottság elérése rövid idő alatt;

- független a szülő jelenlététől - a döntést követően is.

Kampányoltások hátrányai:

- az oltóorvos „kevésbé ismeri” a páciensét;

- az oltóorvos iránti bizalom kevésbé érvényesülhet;

- jól felszerelt orvosi rendelő helyett gyakran csak kevésbé felszerelt orvosi szoba áll rendelkezésre az oltáshoz.

A nem kötelező, de ajánlott védőoltások szülők által való igénylése országosan nem mutat egységes képet, a szám régiónként változó. A tapasztalatok azt mutatják, hogy a fokozottan hátrányos helyzetû településeken (vagyis éppen ott, ahol talán még nagyobb szükség volna a különböző fertőző betegségek elterjedésének a megelőzésére) nagyságrendekkel kevesebben igénylik az ajánlott oltásokat, mint a gazdaságilag jobb helyzetben lévő régiók lakói.

Ezek közül különösen fontos feladat a méhnyakrákot is okozó HPV-vírus elleni oltás széles körben való bevezetése a 9-15 éves korú lányok körében, mert a vakcina a szexuálisan még nem aktív korosztályban a leghatékonyabb. Fontos azt is tudni, hogy a daganatot megelőző védőoltás azonban nemcsak a lányoknak, hanem a fiúknak is ajánlható az egyes HPV okozta, nemi szerveken kialakuló kellemetlen, olykor nehezen kezelhető szemölcsök megelőzésére is, sőt ezzel a populációs szinten kialakuló védettség mértéke még tovább emelhető.

A WHO álláspontja szerint a humán papillomavírusokkal kapcsolatos egészségártalmak népegészségügyi jelentőségűek, ezért a WHO ajánlása, hogy a rutinszerú HPV-vakcinációt illesszék be az országok a nemzeti immunizációs programjukba, amennyiben

- a HPV okozta egészségártalmak az ország prioritásai között szerepelnek;

- a vakcináció programszerúen szervezhető;

- a program folyamatosan és biztonságosan finanszírozható;

- és megfelelően mérlegelték a költséghatékonyságát.

Az oltás elsődleges célpopulációja a HPV-vel még nem találkozott, szexuálisan még nem aktív serdülő lányok csoportja. Mérlegelni kell ennek a korosztálynak a széles körú elérhetőségét, és azt is, hogy az alapimmunizálást három oltással lehet biztosítani, amelynek egy részét más oltással egyidejúleg is lehet alkalmazni, mivel az oltóanyagban élő organizmus nincs. 
Többféle oltási stratégia lehetséges, de a legcélszerúbb, ha a hazai kötelező kampányoltási rendhez igazítjuk azt, így az orvosi vizitek száma is csökkenthető.

Magyarországon az oltás programszerü szervezhetôségét segíti, hogy az elsődleges célpopuláció (12 éves korúak, azaz a 6. osztályosok) már most is szerepelnek a nemzeti oltási rendben, a szintén a szexuális úton terjedő hepatitis B-vírus elleni vakcináció révén. Ehhez az oltási rendben jól illeszthető a HPV elleni védőoltás, amely a forgalomban lévő HPV-vakcinák alkalmazási előírásai szerint a hepatitis B-vírus elleni oltással egy időben adható.

\section{Felhasznált irodalom}

[1] Dorleans, F., et al.: The current state of introduction of humán papillomavirus vaccination into national immunisation schedule in Europe: first result of the Venice 2010 survey. Euro Surveill: 2010, 15. F.

[2] Az Országos Epidemiológiai Központ Módszertani Levele a 2012. évi védőoltásokról.

[3] http://www.who.int./wer/2009/wer8415.pdf

\subsubsection{A felnöttkori méhnyakszürések implementációja}

A méhnyakrák megelőzésének jelenlegi hazai helyzetét röviden összefoglalva megállapítható, hogy a citológiai alapú szervezett méhnyakszúrés széles körben hozzáférhetó a lakosság számára, ugyanakkor a szúrés iránti érdeklődés alacsony. Ezt a helyzetet magyarázza a hazai lakosság egészségkultúrája és egészségszemlélete. A szűrés definíciója szerint a tünet- és panaszmentes lakosság rendszeres vizsgálata. A magyar lakosság ugyanakkor az elmúlt mintegy fél évszázad során olyan irányba szocializálódott, hogy az egészségügyi szolgáltatókat akkor keresse fel, akkor forduljon orvoshoz, ha tüneteket észlel és/vagy panaszoktól szenved. Ennek a szemléletbeli eltérésnek az áttörése nem egyszerü feladat.

Másrészt a széles körű primer prevenció kedvező hazai lakossági fogadtatását előre jelző tény, hogy a nemzetközi statisztikák szerint a preventív védőoltások tekintetében hazánkban az oltási fegyelem kiemelkedően magas. Minimális az oltásról elmaradók száma.

A hazai méhnyakszưrés területén mintegy három évtizede dolgozó szakember véleménye szerint haszonnal járna a speciális hazai viszonyokat figyelembe véve a primer és szekunder prevenció együttes promotálása, a méhnyakszüréseken való részvételre és a HPV elleni védőoltás felvételére történő párhuzamos mozgósítás. Természeten más korosztályt érint a HPV-védőoltás amelynek maximális hasznosulása a 12 . életév körüli korosztályt oltva biztosítható, azaz a szexuális élet elkezdése előtt -, mint a citológiai szürés. Figyelembe veendő tény továbbá, hogy az életkor előrehaladtával fokozatosan nő a citológiai szưrés és csökken a vakcináció jelentősége a méhnyakrák megelőzésében. A HPV onkogén 16/18-as típusait magába foglaló védőoltás széles körü alkalmazása valószínúleg befolyásolja majd a preventív tesztek jövőbeli alkalmazását és azok teljesítményét minimálisan az oltott és nem oltott populációk relációjában.

Fontos szem előtt tartani, hogy a vakcináció hatásfoka a méhnyakrák kialakulásának kockázata csökkentése terén alapvetően meghatározott a vakcinált onkogén HPV-típusok száma, az oltási lefedettség és a védelem tartóssága által. Ugyanakkor további fontos feltétele a méhnyakrákos kockázat jelentős csökkenésének a lefektetett szúrési elórírások további pontos követése a lakosság és a szürés szolgáltatói által. A jelenleg alkalmazott vakcinák széles körû alkalmazásával elérhető 70\%-os kockázatcsökkenés tényleges értékelése csak évtizedek múlva lehetséges, amikor a jelenleg vakcinált 12 éves leányok elérik a 45-50 év közötti életkort. Így hiba lenne az úgynevezett „onkológiai éberség” lazulása, mert ez olyan tendenciákat indíthatna el, amelyek elfedik a vakcináció kedvező hatását.

Személyes tapasztalata a méhnyakszüréssel mintegy három évtizede foglalkozó szakembernek, hogy a hazai leánygyermekes családok egyre szélesebb körében a nevelés részévé vált a méhnyakrák megelőzésére való figyelemfelhívás, miszerint a nemi élet elkezdésével vagy éppen annak elkezdése előtt kötelességszerü teendők vannak ezen a téren. Nevezetesen prioritásként kezelendő a nemi élet elkezdése előtt a védőoltás, ezt követően pedig a szüréseken való megjelenés.

A családokon belüli helyes kommunikációval, az erre való neveléssel az egymás egészségmegőrzésével való törődés életszemléletének kialakításával egyidejûleg lehet előrelépni a primer és szekunder prevenció területén.

Hazai viszonylatban a mintegy 30\%-os lefedettséggel múködő hagyományos méhnyakszűrést szerencsésen egészíthetné ki a tizenéves korosztály jelenleginél szélesebb körű HPV-vakcinációja. A program morbiditásra és mortalitásra kifejtett kedvező hatását növelné, hogy a kialakítandó oltási regiszter biztosíthatja annak a szociálisan hátrányos népességrétegnek az elérését is, amely gyakorlatilag egyáltalán nem hozzáférhető a méhnyakszúrés szervezett, behívásos formája számára.

A HPV-védőoltás finanszírozása terén is forrásokat szabadíthat fel a primer és szekunder prevenció racionális összehangolása. A HPV-védőoltás nem teszi szükségtelenné a hagyományos méhnyakszürést, ugyanakkor az általa biztosított védelem lehetőséget nyújt a méhnyakszűrés későbbi életkorban való elkezdésére és nagyobb intervallummal való végzésére a szürés biztonságának fellazulása nélkül. A szúrési költségek ily módon történő csökkenése jelentős prevenciós forrásokat szabadíthatna fel, a HPV-védőoltások támogatására fordítva azt. Költségbecslések is végezhetők a primer és szekunder prevenció racionális ötvözésével felszabadítható forrásokra vonatkozóan. A citológiai alapú méhnyakszűrést évente végezve a női lakosság teljes lefedettségének feltételezése mellett ennek költ- 
sége mintegy 4,5 milliárd Ft-ra tehető. A szúrés elkezdését a vakcináltak körében 25 éves életkorra posztponálva, majd háromévente végezve azt 65 éves életkorig a szûrés ráfordítása mintegy 3 milliárd Ft-tal lenne csökkenthető. Ezek a becslések a minimális megtakarítást jelzik, ugyanis nem számolnak az átmeneti kategóriába eső rákszürési eredmények ismétlésének, a próbakimetszések és a szövettani vizsgálat költségeivel. Ehhez hozzáadódnak még a kiesett munkaórák költségei is. Természetesen nem hagyhatók figyelmen kívül a méhnyakon végzett, a méhszáj záró struktúráját károsító mútéteknek a fertilitásra gyakorolt kedvezőtlen hatásai sem. A rákmegelőzó állapotok és a korai méhnyakrák miatt végzett mútétek meddőséget eredményezhetnek, és teherbe esés esetén is magasabb a vetélések, az éretlen, valamint a koraszülések aránya.

Mindezen érvek alátámasztják azt a véleményt, hogy hazánkban lényeges előrelépést eredményezne a hagyományos citológiai alapú méhnyakszürés és a HPVellenes védőoltás egyidejű és együttes program keretében történő népszerūsítése, finanszírozása és gyakorlati alkalmazása. 
Kiadja az Akadémiai Kiadó Zrt.

A kiadásért felel az Akadémiai Kiadó Zrt. igazgatója

Szerkesztőség: 1117 Budapest, Prielle Kornélia u. 21-35.

Telefon: 464-8235, 464-8225; Fax: 464-8295

Titkársági e-mail: budai.edit@akkrt.hu

Honlap: www.orvosihetilap.com

Készült: NestPress Kft., 1116 Budapest, Vegyész u. 17-25.

Felelős vezető: Fekete Iván 